\title{
Towards understanding and reducing late side effects of radiotherapy in breast cancer patients
}

Citation for published version (APA):

Brouwers, P. (2020). Towards understanding and reducing late side effects of radiotherapy in breast cancer patients. [Doctoral Thesis, Maastricht University]. Maastricht University. https://doi.org/10.26481/dis.20201023pb

Document status and date:

Published: 01/01/2020

DOI:

10.26481/dis.20201023pb

Document Version:

Publisher's PDF, also known as Version of record

\section{Please check the document version of this publication:}

- A submitted manuscript is the version of the article upon submission and before peer-review. There can be important differences between the submitted version and the official published version of record.

People interested in the research are advised to contact the author for the final version of the publication, or visit the DOI to the publisher's website.

- The final author version and the galley proof are versions of the publication after peer review.

- The final published version features the final layout of the paper including the volume, issue and page numbers.

Link to publication

\footnotetext{
General rights rights.

- You may freely distribute the URL identifying the publication in the public portal. please follow below link for the End User Agreement:

www.umlib.nl/taverne-license

Take down policy

If you believe that this document breaches copyright please contact us at:

repository@maastrichtuniversity.nl

providing details and we will investigate your claim.
}

Copyright and moral rights for the publications made accessible in the public portal are retained by the authors and/or other copyright owners and it is a condition of accessing publications that users recognise and abide by the legal requirements associated with these

- Users may download and print one copy of any publication from the public portal for the purpose of private study or research.

- You may not further distribute the material or use it for any profit-making activity or commercial gain

If the publication is distributed under the terms of Article $25 \mathrm{fa}$ of the Dutch Copyright Act, indicated by the "Taverne" license above, 


\section{Towards understanding and reducing late side effects of radiotherapy in breast cancer patients}

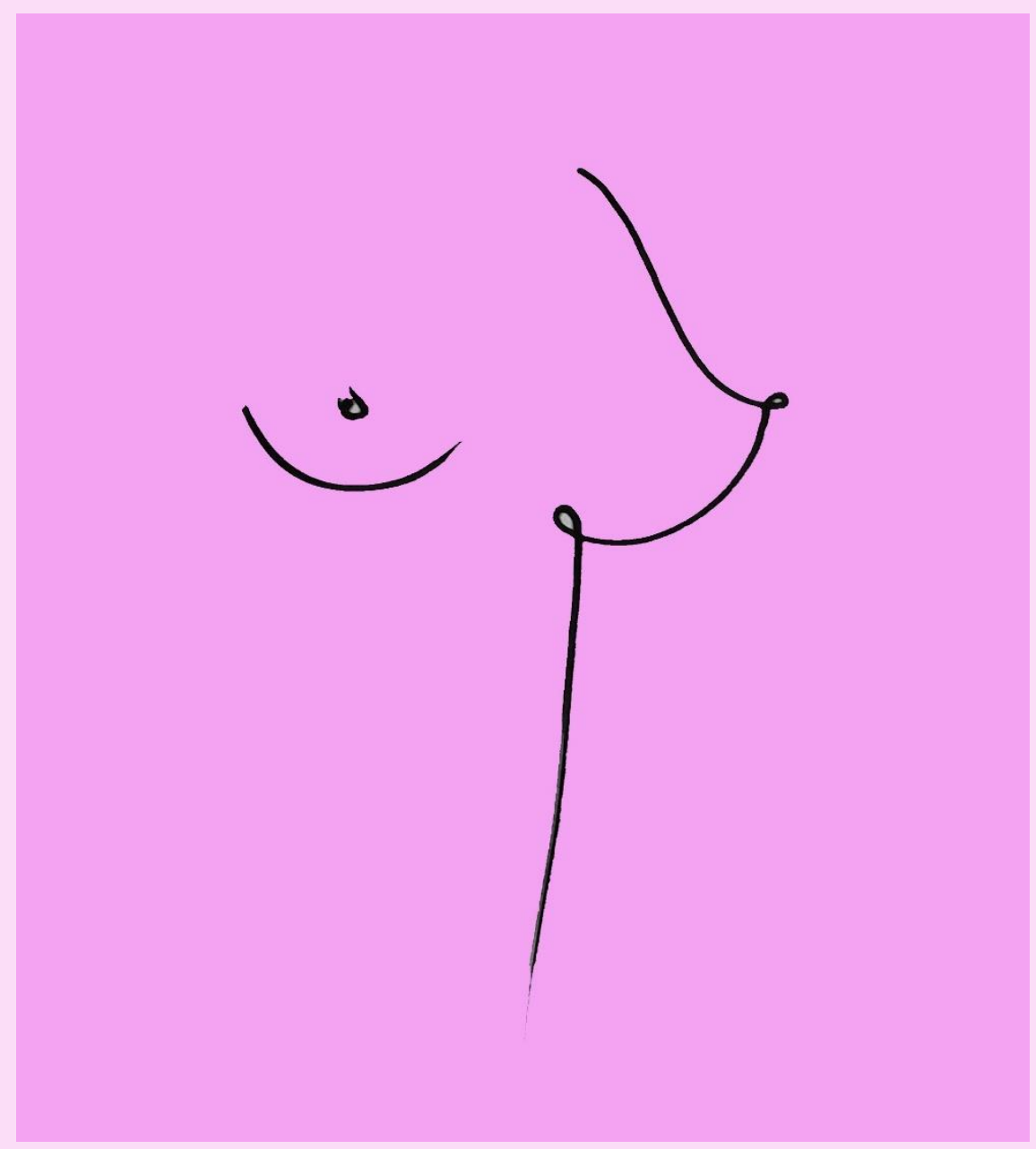

Petronella Jacoba Antonia Maria (Patricia) Brouwers 


\section{Towards understanding and reducing late side effects of radiotherapy in breast cancer patients}

Petronella Jacoba Antonia Maria (Patricia) Brouwers 
@Patricia Brouwers, Maastricht 2020

Cover design: Antoinette Mulder

Printing: Drukkerij Meulenberg 


\title{
Towards understanding and reducing late side effects of radiotherapy in breast cancer patients
}

\begin{abstract}
PROEFSCHRIFT
Ter verkrijging van de graad van doctor aan de Universiteit Maastricht, op gezag van de Rector Magnificus, prof. Dr. Rianne. M. Letschert, volgens het besluit van het college der Decanen In het openbaar te verdedigen op 23 oktober 2020 om 10.00 uur.
\end{abstract}

door

Petronella Jacoba Antonia Maria (Patricia) Brouwers geboren op 23 mei 1980 te de Moer (gemeente Loon op Zand) 


\section{Promotores}

Prof. Dr. L.J. Boersma

Prof. Dr. D. De Ruysscher

\section{Copromotor}

Dr. J.G.M. van Loon

\section{Beoordelingscommissie}

Prof. Dr. R.R.J.W. Van der Hulst (voorzitter)

Dr. H.J. van den Bongard

Prof. dr. I.H.J.T. de Hingh

Dr. S.T.H. Peeters

Dr. A.N. Scholten 


\section{Contents}

$\begin{array}{lll}\text { Chapter } 1 & \text { General introduction and outline of the thesis. } & 7\end{array}$

$\begin{array}{lll}\text { Chapter } 2 & \text { Factors associated with patient-reported cosmetic outcome in } & 19\end{array}$ the Young Boost Breast Trial.

Brouwers et al, Radiother Oncol 2016: 120: 107-113.

Chapter $3 \quad$ Predictors for poor cosmetic outcome in patients with early stage 37 breast cancer treated with breast conserving therapy: Results of the Young boost trial.

Brouwers et al, Radiother Oncol 2018: 128(3):434-441.

Chapter 4 Set-up verification and 2-dimensional electronic portal imaging device dosimetry during breath hold compared with free breathing in breast cancer radiation therapy.

Brouwers et al, Pract Radiat Oncol 2015;5(3):e135-41.

Chapter 5 Are PROMs sufficient to record late outcome of breast cancer 77 patients treated with radiotherapy? A comparison between patient and clinician reported outcome through an outpatient clinic after 10 years of follow up.

Brouwers et al, Radiother Oncol 2018: 126(1):163-169.

Chapter 6 General Discussion 


\section{Chapter 1}

General introduction and outline of the thesis 


\section{General introduction and outline of the thesis}

\section{Breast cancer}

Breast cancer is the most common cancer in women ${ }^{1}$ : in the Netherlands, the lifetime risk of being diagnosed with invasive breast cancer has increased over the past decades from $10.5 \%$ to $13.6 \%$, meaning one of seven women will be diagnosed with invasive breast cancer ${ }^{2}$. At the same time, the oncological outcome of breast cancer patients has improved substantially in the last decades, with a 10 -year survival rate of almost $80 \%$, resulting in an increasing number of long-term survivors ${ }^{2,1}$. Herewith, any late side effects of treatment and their possible negative impact on survival or quality of life are increasingly important for these patients ${ }^{3,4}$. Consequently, there is growing attention for limiting these side effects as much as possible, whilst maintaining the good oncological outcome. Apart from surgery and systemic treatment, radiotherapy plays a major role in the treatment of breast cancer. In patients with early breast cancer, breast conserving therapy, i.e. lumpectomy followed by breast irradiation, is nowadays considered as standard of care. The twenty-year results of the B-06 study showed that in patients with early breast cancer less recurrences occurred after lumpectomy followed by breast irradiation compared to lumpectomy alone, with an equal survival as in patients who received a mastectomy ${ }^{5}$. Adjuvant radiotherapy shows a relative reduction in loco-regional recurrences of $60-70 \%{ }^{6}$ in patients treated with breast conserving surgery. An additional boost to the tumour bed reduces the risk for local failure even further by a factor of $2^{7}$.

For a long time, it has been thought that radiotherapy only reduced local recurrences, but since a few decades we know that radiotherapy also can improve overall survival $\left.\right|^{8,9}$. There is a significant relation between the risk of a local recurrence and overall survival, indicating that by preventing four local recurrences, one breast cancer death could be prevented at 15 years $^{8}$. A large meta-analysis confirmed this one in four rule, but also nuances these numbers. The number of breast cancer deaths avoided per recurrence avoided might be more than one in four in $\mathrm{pN}+$ disease and in high risk pNO disease, and less than one in four for women with intermediate or low risk disease? ${ }^{9}$.

\section{Radiation induced side effects}

Interaction of ionizing radiation with tissue cells causes damage (sometimes irreversible) to the cellular DNA, with cell kill and hereby tissue damage as a result. Although tumour cells are generally more sensitive to radiation compared to normal tissue cells ${ }^{10}$, normal tissue damage does occur. Therefore, the main objective of radiotherapy is to administer a lethal dose to the tumour, while avoiding surrounding normal tissue damage as much as possible. 
In breast cancer, radiotherapy is usually administered after surgery. Therefore, in the majority of patients, no macroscopic tumour is present anymore in the breast and the radiation treatment is aimed at preventing a local recurrence. The whole breast (or partial breast) supplemented or not with elective regional nodal areas is included in the Clinical Target Volume (CTV), defined as the area with possible microscopic disease. Late side effects that have been reported with this loco(regional) irradiation are impaired shoulder function, lymphedema, fibrosis of the breast leading to pain and impaired cosmetic outcome ${ }^{11}$. In addition, radiation-induced lung and cardiac injury may occur ${ }^{12,13}$. The risk of lung toxicity is quite low. In the EORTC $22922 / 10925$ trial only $1.3 \%$ of patients suffered from lung toxicity (fibrosis; dyspnoea; pneumonitis; any lung toxicities) in case of breast irradiation versus $4.3 \%$ in case of elective irradiation of the internal mammary and medial supraclavicular nodes as well at three years follow up ${ }^{14}$. Radiation dose to the heart increases the subsequent risk of coronary heart disease and cardiac mortality: when comparing patients with radiotherapy and without radiotherapy for breast cancer, the relative risks are 1.30 for coronary heart disease and 1.38 for cardiac mortality ${ }^{15}$. In absolute numbers, radiotherapy for breast cancer is associated with an absolute risk increase of 76.4 cases of coronary heart disease and 125.5 cases of cardiac death per 100000 person-years ${ }^{15}$.

Although many side effects can occur, in this thesis we mainly focus on the analysis of cosmetic outcome in the Young Boost Trial (YBT), a large international Randomized Controlled Trial in which the effect of a higher boost dose on local recurrence and cosmetic outcome was investigated. However, we also involve heart damage into the thesis, as heart damage is obviously a very important and potential lethal late toxicity. In the paragraphs below we describe the background of the subjects of this thesis.

\section{Cosmetic outcome and fibrosis}

The EORTC "boost versus no boost" trial showed that by adding a boost to the tumour bed, the risk of local failure can be reduced further compared to irradiation of the whole breast alone ${ }^{16-18}$. The boost versus no boost trial ${ }^{7}$ also showed that the younger patients still remained at a risk of a local failure of $13.5 \%$ percent at ten years, which was deemed unacceptable.

Based upon these results, the YBT was designed in 2003, in which patients of 50 years and younger with early breast cancer were randomized between a standard 16 Gy boost or a high 26 Gy boost or a scheme with a biological equivalent dose following $50 \mathrm{~Gy}$ whole breast irradiation. The YBT is a large international randomized trial in which 2423 patients were included from The Netherlands, France and Germany. 
The first aim of the YBT was to investigate the effect of a higher boost on the local recurrence rate. Since the boost versus no boost trial had also shown that the boost resulted in a worse cosmetic outcome ${ }^{19}$, the second aim was to investigate whether or not there is a significant difference in cosmetic outcome and fibrosis between the high boost group and the low boost group.

In order to deliver a proper radiation treatment with the least possible negative side effects, it is important to have knowledge of the risk factors for fibrosis and a deteriorated cosmetic outcome. Also, we need to know which features are related to the patients' opinion concerning cosmetic outcome.

Defining cosmetic outcome is often considered as controversial, because of its subjective nature. Therefore, besides subjective scores, several automatic methods to score cosmetic outcome are available, assuming that an automatic score is more objective and reproducible. An example of an objective method is BCCT.core, which is a software program which analyses digital photographs in anterior-posterior view, resulting in an objective score for the overall cosmetic outcome: excellent, good, fair or poor ${ }^{20}$. This score is based on symmetry ( 7 features), skin colour and scar visibility. In this thesis, we used the BCCT.core objective score to analyse risk factors for worse cosmetic outcome.

\section{Prevention of cardiac toxicity}

Breast or thoracic wall irradiation is generally largely given using tangential fields. The heart can be partially located within the radiation field in case of left-sided breast cancer or in case of irradiation of the inframammary lymph nodes, both left- as right sided. Darby et $\mathrm{al}^{13}$ published in 2013 a very important paper which described the effect of radiation to the heart in patients for breast cancer. With every Gray to the heart (mean heart dose), rates of major coronary events increase by $7.4 \%$, with no apparent threshold. The overall rate ratio for a major coronary event among women with a history of ischemic heart disease as compared with women with no such history was 6.67. A history of other circulatory diseases, diabetes, chronic obstructive pulmonary disease, smoking, a high body-mass index or a history of regular analgesic use were defined as factors associated with an elevated risk of coronary events. The rate ratio for the presence of one or more of these factors but absence of ischemic heart disease was 1.96 overall. This increase started already within the first 5 years after radiotherapy and continued into the third decade after radiotherapy. Therefore, reduction of irradiated volume and dose to the heart is expected to reduce late heart toxicity and as a result prevent morbidity.

Proton therapy may be able to reduce heart injury. Since proton therapy has recently become available in our country, there was discussion about which patients should be eligible for this new technique. In the Netherlands, proton therapy is only being reimbursed, if there is a clinically relevant 
difference in the probability to develop a certain complication between proton and photon therapy. A national indication protocol must be available, containing validated prognostic models to estimate the complication probability. Cardiac injury is the only endpoint included in the national indication protocol for proton therapy in breast cancer. The risk on acute coronary events is estimated based on the model of Darby et $\mathrm{al}^{9}$ described. Consequently, this model is now also being used in optimizing photon treatment plans, i.e. by applying strategies that reduce the mean heart dose.

Multiple respiratory techniques have been described to spare both heart and lung. All techniques are based on the principle that during deep inspiration the heart moves out of the radiation field. This can be achieved using advanced methods as an Active Breathing Control ( $A B C)$ device ${ }^{21}$ or gating ${ }^{22,23}$, but also using more simple voluntary breath hold techniques ${ }^{22,24,25}$. Although the simple technique is obviously cost attractive, the reproducibility of this voluntary breath hold technique has however been questioned ${ }^{26}$. In this thesis we describe the introduction of voluntary moderately deep inspiration breath hold $(\mathrm{vmDIBH})$ in our institute.

\section{Long term follow up}

In 2007, the Dutch Health Council (DHC) advised to limit follow-up only to those situations where follow-up has been shown to be beneficial for the individual patient.

Therefore, in The Netherlands, follow-up after 5 years of treatment is largely performed by the General Practitioner instead of in the hospital. Consequently, it is extremely difficult for hospitals to obtain long-term outcome data of the breast cancer patients treated in their hospital. Since we consider structural outcome registration an extremely important prerequisite for improving quality of care, we started an outpatient clinic for late outcome of breast cancer patients to explore whether registration of late outcome assessed using validated questionnaires (patient reported outcome measures (PROMs)) is at least as good as an assessment by the caregiver during a live visit at the outpatient clinic.

\section{Outline of this thesis}

In the last decades, the treatment of breast cancer patients has improved substantially and in patients with early breast cancer breast conserving therapy is considered as standard of care ${ }^{5,18}$. In addition, the incidence of breast cancer has risen and the oncological outcome has improved ${ }^{1,2}$, leading to a growing number of breast cancer survivors. Especially in the patient population with a good oncological prognosis, preventing late side effects becomes increasingly important.

The central theme of this thesis was to get insight in several aspects of some late side effects: 
- To predict cosmetic outcome, not only to have clues how to improve cosmetic outcome, but also to use in shared decision making when choosing on radiation treatment. For this purpose, we used the data of the Young Boost Trial. In this trial the effect of a higher boost dose on local recurrence and cosmetic outcome was investigated in patients $\leq 50$ years of age. We analysed the cosmetic outcome of the Young Boost Trial.

- To prevent late side-effects, i.e. cardiac injury, by investigating whether our technique of Voluntary moderately Deep Inspiration Breath Hold (vmDIBH) is actually reproducible.

- To record all late-side effects in a structured way:

$\bigcirc$ to identify patients needing additional care

○ to enable development of prognostic models

O to be able to compare outcome data with other radiation therapy centres or with historic controls.

Consequently, the three main aims of this thesis are:

1. To determine which factors are important for:
a. patient reported cosmetic outcome
b. fibrosis (scored by physician)
c. cosmetic outcome (based on the objective BCCT.core)

To determine these factors, we analysed which risk factors are associated with a worse cosmetic outcome in the YBT trial, based on the objective BCCT.core score. Further, we report on the amount of moderate/severe fibrosis and define the risk factors for moderate/severe fibrosis in the boost area (Chapters $2 \& 3$ ).

2. To investigate/develop an easy but reproducible and affordable breath hold manoeuvre to reduce the dose to the heart (Voluntary moderately Deep Inspiration Breath Hold, vmDIBH).

Chapter 4 reports on the careful step-by-step introduction of voluntary moderately deep inspiration breath hold ( $\mathrm{vmDIBH})$ in our institute. To investigate the reproducibility of vmDIBH, we compared set-up data of patients treated in vmDIBH and with free breathing patients.

3. To investigate whether patient reported outcome measures (PROMS) are sufficiently reliable to record late outcome (Chapter 5). 
To be able to investigate this, we developed an outpatient clinic for late outcome (OCLO) and compared PROMS to the results found at the live visit to the outpatient clinic.

Finally, the findings of these thesis are discussed in chapter 6 . A summary and Dutch translation of the summary is provided in chapter 7. 


\section{References}

1. https://www.cijfersoverkanker.nl/. https://www.cijfersoverkanker.nl/.

2. Van Der Waal D, Verbeek ALM, Den Heeten GJ, Ripping TM, Tjan-Heijnen VCG, Broeders MJM. Breast cancer diagnosis and death in the Netherlands: A changing burden. Eur J Public Health. 2015;25(2):320-324. doi:10.1093/eurpub/cku088.

3. Perry S, Kowalski TL, Chang $\mathrm{CH}$. Quality of life assessment in women with breast cancer: Benefits, acceptability and utilization. Health Qual Life Outcomes. 2007;5:1-14. doi:10.1186/1477-7525-5-24.

4. Ewertz $\mathrm{M}$, Jensen $\mathrm{AB}$. Late effects of breast cancer treatment and potentials for rehabilitation. Acta Oncol. 2011;50(2):187-193. doi:10.3109/0284186X.2010.533190.

5. Fisher, Bernard; Anderson, Stewart, Bryant, John, Margolese, Richard G; Deutch, Melvin; Fischer, Edwin R; Jeong, Jong-Hyeon; Wolmark N. TWENTY-YEAR FOLLOW-UP OF A RANDOMIZED TRIAL COMPARING TOTAL FOR THE TREATMENT OF INVASIVE BREAST CANCER. N Engl J Med. 2002;347(16):1233-1241.

6. Clarke M, Collins R, Darby $\mathrm{S}$, et al. Effects of radiotherapy and of differences in the extent of surgery for early breast cancer on local recurrence and 15-year survival: an overview of the randomised trials. Lancet. 2005;366(9503):2087-2106. doi:10.1016/S0140-6736(05)67887-7.

7. Poortmans PM, Collette $L$, Bartelink $\mathrm{H}$, et al. The addition of a boost dose on the primary tumour bed after lumpectomy in breast conserving treatment for breast cancer. A summary of the results of EORTC 22881-10882 "boost versus no boost" trial. Cancer Radiother. 2008;12(67):565-570. doi:10.1016/j.canrad.2008.07.014.

8. Rinaa S. Punglia, M.D., M.P.H., Monica Morrow, M.D., Eric P. Winer MD, and Jay R. Harris MD. Local therapy and survival in breast cancer. N Engl J Med. 2007;357(10):1051; author reply 1052. doi:10.1056/NEJMra065241.

9. Darby S, McGale P, Correa C, et al. Effect of radiotherapy after breast-conserving surgery on 10-year recurrence and 15-year breast cancer death: Meta-analysis of individual patient data for 10801 women in 17 randomised trials. Lancet. 2011;378(9804):1707-1716. doi:10.1016/S0140-6736(11)61629-2.

10. Michael Joiner and Albert van der Kogel. Basic Clinical Radiobiology.; 2009.

11. Petersen C, Würschmidt F. Late Toxicity of Radiotherapy: A Problem or a Challenge for the Radiation Oncologist? Breast Care (Basel). 2011;6(5):369-374. doi:10.1159/000334220.

12. Aznar MC, Duane FK, Darby SC, Wang Z, Taylor CW. Exposure of the lungs in breast cancer radiotherapy: A systematic review of lung doses published 2010-2015. Radiother Oncol. 2018;126(1):148-154. doi:10.1016/j.radonc.2017.11.022.

13. Darby SC, Ewertz M, McGale $P$, et al. Risk of ischemic heart disease in women after radiotherapy for breast cancer. N Engl J Med. 2013;368(11):987-998. doi:10.1056/NEJMoa1209825.

14. Matzinger $\mathrm{O}$, Heimsoth I, Poortmans $\mathrm{P}$, et al. Toxicity at three years with and without irradiation of the internal mammary and medial supraclavicular lymph node chain in stage i to III breast cancer (EORTC trial 22922/10925). Acta Oncol (Madr). 2010;49(1):24-34. doi:10.3109/02841860903352959.

15. Cheng YJ, Nie XY, Ji CC, et al. Long-term cardiovascular risk after radiotherapy in women with 
breast cancer. J Am Heart Assoc. 2017;6(5). doi:10.1161/JAHA.117.005633.

16. Bartelink, Harry, M.D., Ph.D., Horiot, Jean-Claude, M.D., Ph.D., Poortmans, Philip, M.D., Struikmans, Henk, M.D., Ph.D., Jager, Jos, M.D., Ph.D., Hoogenraad, Willem, M.D., Collette, Laurence, M.Sc., and Pierart, Marianne, M.Sc. for the EO for R and T of CR and BC groups. Recurrence Rates after Treatment of Breast Cancer with Standard Radiotherapy With or Without Additional Radiation. New Engl J Med J. 2001;345(19):1378-1387.

17. Bartelink $\mathrm{H}$, Horiot J-C, Poortmans PM, et al. Impact of a higher radiation dose on local control and survival in breast-conserving therapy of early breast cancer: 10-year results of the randomized boost versus no boost EORTC 22881-10882 trial. J Clin Oncol. 2007;25(22):32593265. doi:10.1200/JCO.2007.11.4991.

18. Bartelink $\mathrm{H}$, Maingon $\mathrm{P}$, Poortmans $\mathrm{P}$, et al. Whole-breast irradiation with or without a boost for patients treated with breast-conserving surgery for early breast cancer : 20-year follow-up of a randomised phase 3 trial. Lancet Oncol. 2015;16:47-56. doi:10.1016/S14702045(14)71156-8.

19. Vrieling C, Collette L, Fourquet A, et al. The Influence of the Boost in Breast-conserving Therapy on Cosmetic Outcome in the EORTC "Boost versus no Boost" Trial. Int J Radiat Oncol. 1999;45(3):677-685.

20. Cardoso JS, Cardoso MJ. Towards an intelligent medical system for the aesthetic evaluation of breast cancer conservative treatment. Artif Intell Med. 2007;40(2):115-126. doi:10.1016/j.artmed.2007.02.007.

21. Remouchamps VM, Letts $\mathrm{N}$, Vicini $\mathrm{F}$ a., et al. Initial clinical experience with moderate deepinspiration breath hold using an active breathing control device in the treatment of patients with left-sided breast cancer using external beam radiation therapy. Int J Radiat Oncol. 2003;56(3):704-715. doi:10.1016/S0360-3016(03)00010-5.

22. Korreman SS, Pedersen AN, Aarup LR, Nøttrup TJ, Specht L, Nyström H. Reduction of cardiac and pulmonary complication probabilities after breathing adapted radiotherapy for breast cancer. Int J Radiat Oncol Biol Phys. 2006;65(5):1375-1380. doi:10.1016/j.jjrobp.2006.03.046.

23. Korreman SS, Pedersen AN, Nøttrup TJ, Specht L, Nyström H. Breathing adapted radiotherapy for breast cancer: comparison of free breathing gating with the breath-hold technique. Radiother Oncol. 2005;76(3):311-318. doi:10.1016/j.radonc.2005.07.009.

24. Pedersen AN, Korreman S, Nyström H, Specht L. Breathing adapted radiotherapy of breast cancer: reduction of cardiac and pulmonary doses using voluntary inspiration breath-hold. Radiother Oncol. 2004;72(1):53-60. doi:10.1016/j.radonc.2004.03.012.

25. Lu HM, Cash E, Chen MH, et al. Reduction of cardiac volume in left-breast treatment fields by respiratory maneuvers: a CT study. Int J Radiat Oncol Biol Phys. 2000;47(4):895-904. http://www.ncbi.nlm.nih.gov/pubmed/10863057.

26. Skyttä $\mathrm{T}$, Kapanen $\mathrm{M}$, Laaksomaa $\mathrm{M}$, et al. Improving the reproducibility of voluntary deep inspiration breath hold technique during adjuvant left-sided breast cancer radiotherapy. Acta Oncol (Madr). 2016;55(8):970-975. doi:10.3109/0284186X.2016.1161823. 


\section{Chapter 2}

\section{Factors associated with patient-reported cosmetic outcome in the Young Boost Breast Trial}

Patricia J.A.M. Brouwers*, Erik van Werkhoven*, Harry Bartelink, Alain Fourquet, Claire Lemanski, Judith van Loon, John H. Maduro, Nicola S. Russell, Luc J.E.E. Scheijmans, Dominic A.X. Schinagl, Antonia H. Westenberg, Philip Poortmans, Liesbeth J. Boersma, on behalf of the Young Boost Trial research group

* These authors contributed equally as the first author

Radiotherapy and Oncology 120 (2016) 107-113 


\begin{abstract}
Purpose: To investigate which factors are related to patient reported cosmetic outcome (PRCO) after breast conserving therapy.

Methods: From 2004 to 2011, 2421 cT1-2NO-2a breast cancer patients were randomised in the Young Boost Trial between a 16 and a 26 Gy boost to the tumour bed. Cosmesis was scored subjectively by the patient and physician, and objectively using BCCT.core, at baseline, one and four years after treatment. Presence of fibrosis, QoL and rib pain at four years were also scored. Data were complete for 864 patients. The relation between the separate components was investigated using a proportional odds model.
\end{abstract}

Results: Of the 7 BCCT.core parameters, the distance from nipple to inframammary fold and the length of the breast contour were significantly related to the overall PRCO at four years. Patients with more fibrosis and poorer QoL scored their cosmesis worse, while rib pain was not related. The agreement between the different scores was low (kappa 0.26-0.42).

Conclusion: The distance from nipple to inframammary fold, the length of the breast contour and the severity of fibrosis were the main factors related to patient-reported cosmetic outcome. Patients with better QoL scored their cosmesis better. 


\section{Introduction}

The EORTC boost-no boost trial showed that adding a $16 \mathrm{~Gy}$ boost to the primary tumour bed after 50 Gy whole breast irradiation, reduces the local recurrence rate (LRR) with $35 \%{ }^{1}$. Nevertheless, even after a boost, the LRR in young patients ( $\leq 50$ years of age) remained higher than $1 \%$ per year. Therefore, in 2004, the Young Boost trial (YBT) was launched (NCT00212121), with the primary aim to investigate whether a higher boost dose of $26 \mathrm{~Gy}$ would further reduce the LRR in young patients. Since the boost-no boost trial showed that the boost led to a worse cosmetic outcome ${ }^{2}$, cosmetic outcome was an important secondary endpoint in the YBT.

Scoring cosmesis is difficult and often considered as controversial, because of its subjective nature. For example: Mukesh et al. found that physicians judged cosmetic outcome to be superior after Intensity Modulated Radiotherapy (IMRT) compared to 2D radiotherapy, whereas the patient reported cosmetic outcome (PRCO) showed no benefit of IMRT ${ }^{3,4}$. A recent analysis of the START trials showed that despite a low agreement between different scoring methods of cosmetic outcome, each scoring method could sufficiently discriminate different fractionation schedules ${ }^{5}$. In most studies different scoring methods are reported, including patient questionnaires, scoring by professionals (or a panel) and/or a photographic assessment using objective and reproducible software programs, such as BCCT.core ${ }^{6}$ or $\mathrm{BAT}^{7}$.

Although the objective methods seem to be the most attractive due to their good reproducibility, they are mainly based on measures to quantify asymmetry, assuming that symmetry is the most important determinant for PRCO. However, if that were true, a much better correlation between PRCO and objective measures would be expected than described in literature. We hypothesised that specific aspects of symmetry (e.g. nipple position) are more important for patients than other aspects (e.g. breast size), and that other factors such as pain or palpable firmness of the breast also influence PRCO. The aim of the current paper was therefore to prospectively investigate which objective cosmetic factors are associated with PRCO in the YBT. We also analysed the relation between fibrosis, pain and quality of life (QoL) with PRCO.

\section{Patients and methods}

Patient population and treatment

Patients younger than 51 years with non-metastatic, histologically proven invasive breast cancer, pT12 pNO-2 $\mathrm{a}^{8}$, with an Eastern Cooperative Oncology Group (ECOG) performance scale ${ }^{9} \leq 2$, were eligible for the trial. Tumours were completely removed by wide local excision, although focally involved margins were allowed, defined as: "tumour (ductal carcinoma in situ or invasive carcinoma) on ink in an area of less than $4 \mathrm{~mm}$ ". Sentinel lymph node biopsy and/ or axillary lymph node dissection had to 
be performed. No neo-adjuvant systemic treatment was allowed. No previous history of malignant disease, except adequately treated carcinoma in situ of the cervix or basal cell carcinoma of the skin was allowed.

Patients were randomised to a standard 16 Gy or a high 26 Gy boost to the tumour bed after $50 \mathrm{~Gy}$ whole breast irradiation. Other fractionation schemes, including simultaneous integrated boost techniques were allowed as well, as long as the biologically equivalent dose, calculated with an $\alpha / \beta$ of 10 for tumour, was similar. Stratification factors were age $(<>40 \mathrm{yr})$, pathological tumour size $(<>3$ $\mathrm{cm}$ ), oestrogen receptor status, nodal status, interstitial/external boost and institute. Patients were stratified at the time of randomisation using a "randomisation by minimisation" technique.

The study was centrally approved by the medical ethical committee of the Netherlands Cancer Institute and by the local medical ethics committees. All patients gave their written informed consent to participate. The study was registered at https://clinicaltrials.gov/show/NCT00212121.

\section{Cosmetic outcome}

Cosmesis was scored prior to radiation therapy, at one year and four years of follow-up.

\section{BCCT.core software 6,10}

Digital photographs in anterior-posterior view were analysed using the BCCT.core software program, resulting in an objective score for the overall cosmetic outcome: excellent, good, fair or poor. This score is based on symmetry, skin colour and scar visibility (Fig. 1). The seven features of symmetry in the BCCT.core program are:

- breast retraction assessment (BRA)

- $\quad$ level of lower breast contour (LBC)

- $\quad$ upward nipple retraction (UNR)

- breast compliance evaluation (BCE; distance from nipple to inframammary fold)

- $\quad$ breast contour difference (BCD)

- $\quad$ breast area difference (BAD)

- $\quad$ breast overlap difference (BOD)

For all symmetry features a relative value was calculated by the program resulting in a pBRA, pLBC etcetera. An example of these relative values is shown in Fig. 1. 


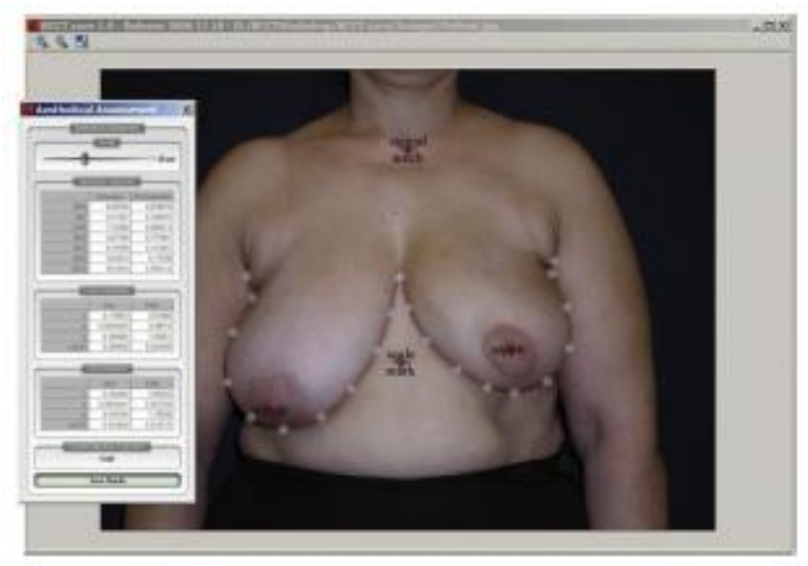

B: Breast Retraction Assessment

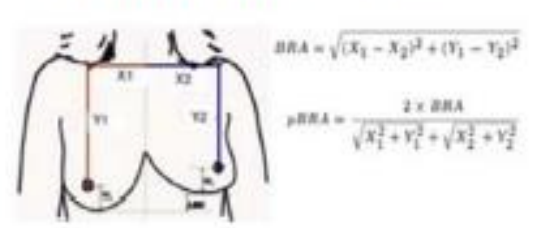

D: Breast Overlap Difference (BOD)

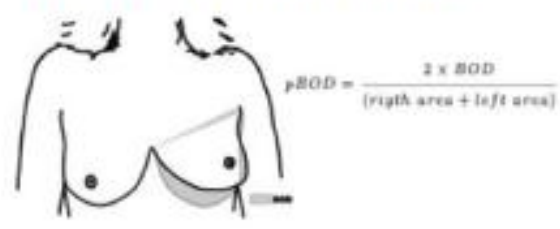

1C: Lower Breast Contour (LBC)

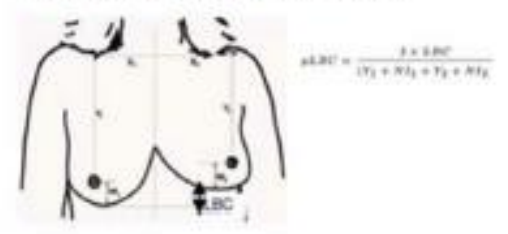

Fig. 1. BCCT.core software program. In (A) a screenshot of the program is shown, in (B-D) examples of some BCCT.core parameters, including formulas for the relative value.

(A) Screenshot of the BCCT.core software program. (B) Breast Retraction Assessment (BRA).

(C) Lower Breast Contour (LBC). (D) Breast Overlap Difference (BOD).

\section{Physician's score}

Physicians scored using the Harris scale on overall cosmetic outcome: excellent, good, fair or poor ${ }^{11}$.

\section{Patient's questionnaire}

The PRCO was determined by asking patients to complete the questionnaire developed by Sneeuw et $\mathrm{al}^{12}$. In this validated questionnaire overall cosmetic outcome was rated on a five-point scale: very satisfied, satisfied, not dissatisfied, dissatisfied and very dissatisfied. The patients were also asked to rate the difference between the treated breast and the untreated breast in terms of scar visibility, 
difference in size, shape, colour, nipple position, and firmness on a four-point scale: no difference, small difference, quite a lot difference, or a large difference.

\section{Other variables}

At the same time points fibrosis (whole breast) was scored by the physician on a four-point scale. The presence of rib pain was scored separately (yes/no).

At four years, quality of life (QoL) was scored using the EORTC QLQ C-30 questionnaire ${ }^{13}$. The global QoL was measured on a scale from 1 to 7 . Emotional functioning was measured on a multi-item scale ranging from 0 to 100 . The parameter value was calculated for a difference of 10 points. Depression was measured at a scale from 1 to 4 . A higher score on the functional scale and global QoL implies better score, while a higher score on the depression scale implies more symptoms.

\section{Analysis}

First, we analysed the correlation of overall cosmetic outcome between the three scoring methods, and between fibrosis scored by the physician and firmness of the breast scored by the patient.

Secondly, we analysed the seven features of BCCT.core in a proportional odds model, to investigate which parameters were related to the PRCO at four years. Also, we analysed whether fibrosis, presence of rib pain or QoL was related to the PRCO.

To evaluate the correlation between the different factors and overall cosmetic outcome, we defined two categories: satisfactory overall cosmetic outcome and unsatisfactory overall cosmetic outcome. Excellent and good as well as very satisfied and satisfied were grouped as 'satisfactory'; fair and poor, not dissatisfied, dissatisfied, and very dissatisfied were grouped as 'unsatisfactory'.

\section{Statistics}

Agreement between the three different scoring systems was calculated by Cohen's kappa statistics. The kappa coefficient $(k)$ is a common measure for agreement ${ }^{14}$. The overall cosmetic outcome was evaluated on a five-point scale by the patient's questionnaire but on a four-point scale by the BCCT.core software and physician. Therefore, the agreement of the overall cosmetic outcome was assessed using the grouped dichotomised outcome variable as described above. For the agreement on individual (separate) cosmetic outcome parameters, all three used a four-point scale and therefore a weighted kappa (wk) was used, where the weights were chosen quadratic. A value of $0-0.2$ for $k$ indicates a slight agreement, 0.2-0.4 indicates a fair agreement, 0.4-0.6 indicates a moderate agreement, 0.6-0.8 indicates a substantial agreement and a value of 0.8-1.0 indicates an almost perfect agreement. 
Associations between PRCO and the seven BCCT.core parameters were assessed with proportional odds models, taking into account the ordinal nature of the outcome. For each type a higher score means a worse outcome. An important assumption of this cumulative link model is that the association between each pair of outcome groups is the same, so that for example the comparison between a score of 1 versus a score of 2, 3 or 4 , and the comparison of 1 or 2 versus 3 or 4 can be modelled by the same parameter. This is called the proportional odds assumption. To assess whether pain, fibrosis or QoL parameters were associated with worse PRCO, these were analysed in models where the BCCT.core outcome was entered as a covariate. The adjustment for BCCT.core outcome gives the parameters for fibrosis, rib pain, or QoL the interpretation of what the difference would be between two patients with the same BCCT.core outcome who differ only in their fibrosis, rib pain or QoL. The QoL parameters were entered as a continuous variable in the model.

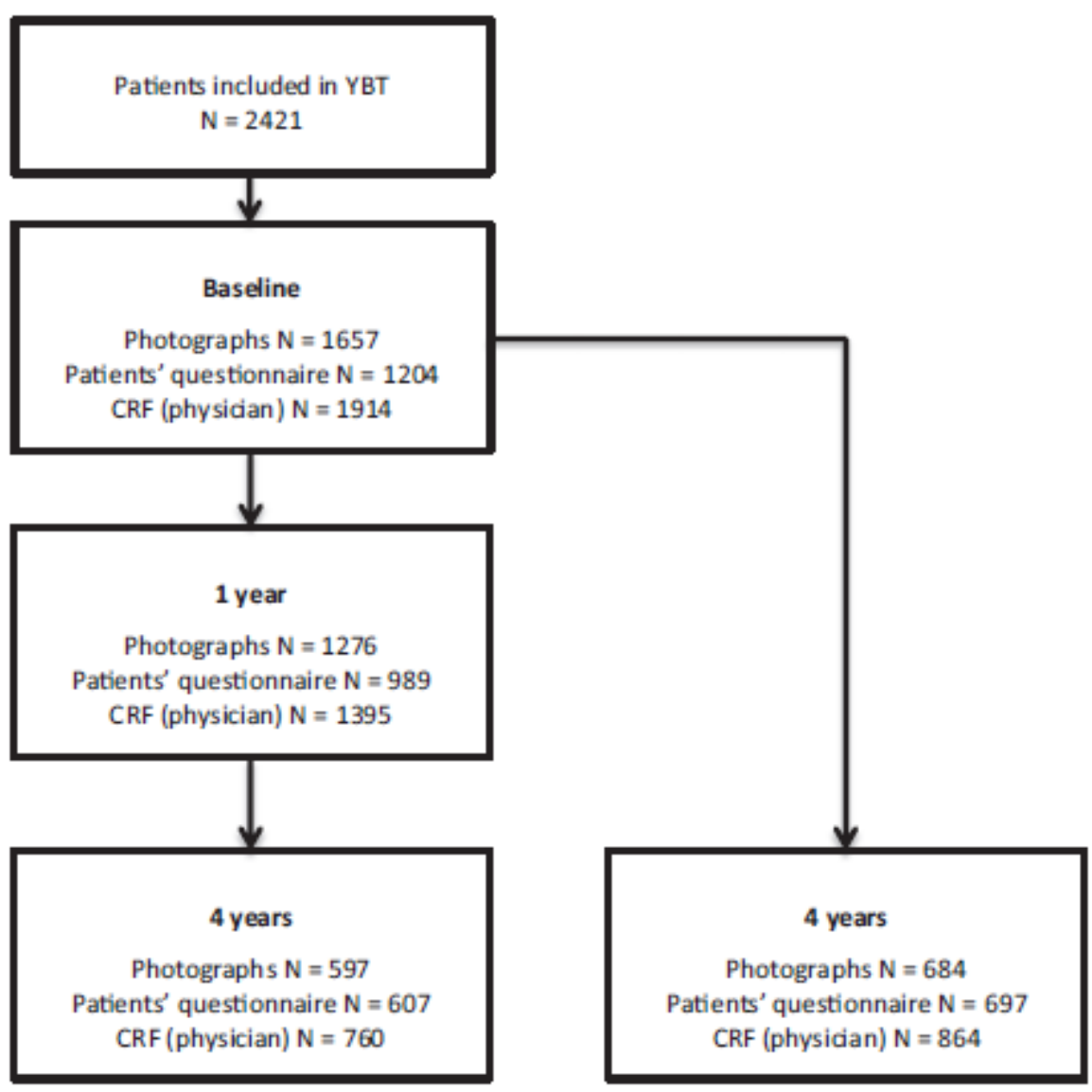

Fig. 2. Flow diagram of available and evaluable digital photographs, available patients' questionnaires and completed Case Report Form (CRF) of all institutes per July 2014. 


\section{Results}

Between 2004 and 2011, 2421 breast cancer patients were included in 18 institutes from The Netherlands, 13 institutes from France and 1 institute from Germany. 1211 patients were randomised to receive a standard $16 \mathrm{~Gy}$ boost and 1210 patients to a high $26 \mathrm{~Gy}$ boost.

Median age was 45 years (range 19-51), 19\% was younger than 40 years old. $72 \%$ of patients had a $\mathrm{T} 1$ tumour and $28 \%$ of patients had a T2 tumour. $61 \%$ of patients received adjuvant chemotherapy and $39 \%$ did not receive adjuvant chemotherapy. Median follow-up at the time of this analysis was 51 months.

At four years we had evaluable digital photographs of 805 patients, of whom 684 also had an evaluable photograph at baseline. 1204 patients filled in the questionnaire at baseline, of whom 697 filled one in at four years too. The cosmetic result was scored by the physician for 1914 patients at baseline, and for 864 at both baseline and 4 years (Fig. 2).

Overall cosmetic outcome for the different scoring systems, and correlation between scoring systems At four years, the BCCT.core program yielded a 'satisfactory' (i.e. excellent or good) overall cosmetic outcome in $61 \%$ of patients. The physicians and patients scored the overall cosmetic outcome as 'satisfactory' in $56 \%$ and $57 \%$ of patients, respectively. The agreement between the physician and the patient scores was moderate $(k=0.42)$, between the patient and BCCT.core fair, and between the physician and BCCT.core scores the agreement was fair, with $\mathrm{k}$ values of 0.26 and 0.39 , respectively. The agreement between firmness scored by the patient and the grade of fibrosis scored by the physician was fair ( $w \mathrm{k}=0.36,95 \% \mathrm{Cl} 0.29-0.42)$ (Table 1 ).

\begin{tabular}{lccccc}
\hline \hline & \multicolumn{5}{c}{ Patients' score of firmness } \\
\cline { 2 - 7 } & $\begin{array}{l}\text { no } \\
\text { difference }\end{array}$ & $\begin{array}{l}\text { little } \\
\text { difference }\end{array}$ & $\begin{array}{l}\text { quite a lot } \\
\text { difference }\end{array}$ & $\begin{array}{l}\text { large } \\
\text { difference }\end{array}$ & $\begin{array}{c}\text { total number } \\
\text { of patients }\end{array}$ \\
\hline Physician: no fibrosis & 70 & 101 & 28 & 11 & 210 \\
Physician: mild fibrosis & 70 & 157 & 63 & 19 & 309 \\
Physician: moderate fibrosis & 19 & 96 & 77 & 25 & 217 \\
Physician: severe fibrosis & 3 & 19 & 20 & 27 & 69 \\
\hline total number of patients & 162 & 373 & 188 & 82 & 805 \\
\hline \hline
\end{tabular}

Table 1. Agreement between fibrosis scored by the physician and the firmness scored by the patient at four years, $w \mathrm{k}=0.36(95 \% \mathrm{Cl} 0.29-0.42)$. Firmness was scored in the questionnaire of Sneeuw by comparing the treated breast with the contralateral breast. 
Objective factors associated with patient reported cosmetic outcome

Of the seven BCCT.core parameters, $\mathrm{pBCE}$ (distance from nipple to inframammary fold) and $\mathrm{pBCD}$ (length of breast contour) were significantly associated with a worse PRCO at four years (Table 2). Patients with fibrosis had worse PRCO than patients without fibrosis, even when the objective score based on BCCT.core was similar (i.e. after adjustment for it). The same was true for difference in firmness scored by the patient. However, the presence of rib pain had no influence (Table 3).

Of the EORTC QLQ C-30 questionnaire, we analysed whether emotional functioning, feelings of depression and/or global quality of life influenced PRCO. For the same BCCT.core score, patients with a higher emotional functioning or better global QoL had a better PRCO, whereas patients with feelings of depression had a worse PRCO (Table 4).

\begin{tabular}{lccc}
\hline \hline & Odds radio & $\begin{array}{c}95 \% \text { confidence } \\
\text { interval }\end{array}$ & p-value \\
\hline \hline pBRA & 1.319 & $0.904-1.921$ & 0.150 \\
pLBC & 1.142 & $0.792-1.648$ & 0.477 \\
pUNR & 1.056 & $0.723-1.544$ & 0.779 \\
pBCE & 1.177 & $1.008-1.375$ & $\mathbf{0 . 0 4 0}$ \\
pBCD & 1.718 & $1.024-2.894$ & $\mathbf{0 . 0 4 1}$ \\
pBAD & 0.856 & $0.540-1.352$ & 0.505 \\
pBOD & 1.038 & $0.764-1.409$ & 0.812 \\
\hline \hline
\end{tabular}

Table 2. Proportional odds model for Patient Reported Cosmetic Outcome (PRCO) based on the seven BCCT.core parameters. The symmetry features are dimensionless. Significant $p$-values are indicated in bold. An odds ratio $>1$ means a worse PRCO. The 7 features of symmetry in the BCCT.core program are: breast retraction assessment (BRA); level of lower breast contour (LBC); upward nipple retraction (UNR); breast compliance evaluation (BCE; distance from nipple to inframammary fold); breast contour difference (BCD); breast area difference (BAD); breast overlap difference (BOD). The pre-suffic refers to the relative value of this parameter calculated by the program. 


\begin{tabular}{|c|c|c|c|}
\hline & Odds ratio & 95\% Confidence interval & p Value \\
\hline \multicolumn{4}{|l|}{ A } \\
\hline BCCT.core score: 2 & 1.668 & $1.058-2.641$ & 0.028 \\
\hline BCCT.core score: 3 & 3.856 & $2.348-6.372$ & $<0.001$ \\
\hline BCCT.core score: 4 & 9.479 & $4.835-18.729$ & $<0.001$ \\
\hline Fibrosis score: minor & 1.183 & $0.797-1.760$ & 0.404 \\
\hline Fibrosis score: moderate & 2.022 & $1.314-3.121$ & 0.001 \\
\hline Fibrosis score: severe & 2.519 & $1.372-4.635$ & 0.003 \\
\hline \multicolumn{4}{|l|}{$B$} \\
\hline BCCT.core score: 2 & 1.683 & $1.086-2.618$ & 0.020 \\
\hline BCCT.core score: 3 & 2.735 & $1.695-4.431$ & $<0.001$ \\
\hline BCCT.core score: 4 & 4.6163 & $2.427-8.812$ & $<0.001$ \\
\hline Difference firmness: small & 1.700 & $1.152-2.516$ & 0.008 \\
\hline Difference firmness: quite a lot & 5.207 & $3.291-8.288$ & $<0.001$ \\
\hline Difference firmness: large & 16.262 & $8.839-30.242$ & $<0.001$ \\
\hline \multicolumn{4}{|l|}{ C } \\
\hline BCCT.core score: 2 & 1.772 & $1.140-2.765$ & 0.011 \\
\hline BCCT.core score: 3 & 4.696 & $2.926-7.585$ & $<0.001$ \\
\hline BCCT.core score: 4 & 11.763 & $6.265-22.269$ & $<0.001$ \\
\hline Rib pain score: some & 1.123 & $0.746-1.690$ & 0.577 \\
\hline Rib pain score: moderate & 0.945 & $0.235-2.690$ & 0.915 \\
\hline Rib pain score: severe & 1.988 & $0.531-7.567$ & 0.306 \\
\hline
\end{tabular}

Table 3. Proportional odds model for patients' satisfaction with A: fibrosis scored by physician and BCCT.core score as covariate, $\mathrm{B}$ : difference in firmness scored by the patient and BCCT.core score as covariate and in C: rib pain and BCCT.core score as covariate. Odds ratios higher than 1 indicate that a higher value of the parameter was associated with a worse patient satisfaction. Significant $p$ values are indicated in bold. 


\begin{tabular}{llll}
\hline & Odds ratio & $95 \%$ Confidence interval & p Value \\
\hline A & & & 0.053 \\
BCCT.core score: 2 & 1.614 & $0.996-2.623$ & $<0.001$ \\
BCCT.core score: 3 & 4.885 & $2.902-8.286$ & $<0.001$ \\
BCCT.core score: 4 & 8.507 & $4.283-17.052$ & $\mathbf{0 . 0 0 2}$ \\
Emotional functioning & 0.881 & $0.813-0.955$ & \\
\hline B & & & $\mathbf{0 . 0 4 3}$ \\
BCCT.core score: 2 & 1.648 & $1.018-2.679$ & $<0.001$ \\
BCCT.core score: 3 & 4.825 & $2.867-8.179$ & $<0.001$ \\
BCCT.core score: 4 & 9.250 & $4.670-18.498$ & $\mathbf{0 . 0 0 9}$ \\
Feelings of depression & 1.366 & $1.081-1.724$ & 0.051 \\
\hline C & & & $<0.001$ \\
BCCT.core score: 2 & 1.621 & $0.999-2.638$ & $<0.001$ \\
BCCT.core score: 3 & 4.709 & $2.796-7.988$ & $\mathbf{0 . 0 0 1}$ \\
BCCT.core score: 4 & 8.618 & $4.318-17.347$ & $0.685-0.909$ \\
Global quality of life & 0.790 & & \\
\hline \hline
\end{tabular}

Table 4.

Proportional odds model for Patient Reported Cosmetic Outcome (PRCO) and quality of life with $\mathrm{BCCT}$.core as covariate. A: emotional functioning with BCCT.core as covariate, $\mathrm{B}$ : feelings of depressing and C: global quality of life with BCCT.core as covariate. Significant p-values are indicated in bold. For BCCT core parameters, an odds ratio $>1$ means a worse PRCO. For Emotional functioning, Global quality of life, and depression an odds ratio $>1$ means worse PRCO in case of worse Emotional functioning, QoL, or more feelings of depression.

\section{Discussion}

The most important parameters related to PRCO after BCT in the YBT were the distance from nipple to inframammary fold and the length of breast contour. Also, the severity of fibrosis (physician) and the difference in firmness (patient) was related to the PRCO, independent of the BCCT.core score, suggesting that indeed a palpable firmness subjectively influences the patient's opinion on cosmesis. Rib pain was not related to the PRCO. 


\section{Comparison with the literature}

Christie et $\mathrm{a}^{15}$ found, in a population of 47 patients, that a greater degree of upward retraction of the nipple was the most powerful determinant of PRCO. This may be inversely related to the $\mathrm{PBCE}$, i.e. the distance from nipple to inframammary fold, which we found in our study.

Patient's mental state might influence PRCO as well. Brunault et al. showed that depression is associated with patient-perceived cosmetic changes ${ }^{16}$. Patients with a probable depression perceived the treated breast to be larger, more deformed and having worse skin pigmentation than nondepressed patients ${ }^{16}$.

The current study finds similar results: patients with feelings of depression had worse PRCO than patients with better emotional functioning or better global QoL. However, it is difficult to distinguish between cause and effect in this matter. It might also be true that a better cosmetic result yields a better QoL.

Recently the cosmetic results of the START trials were published. In this study, PRCO of 1870 patients was unaffected by anxiety and depression ${ }^{5}$. A possible explanation for the different findings could be the difference in age, since in the Cambridge IMRT trial young age was also found to influence the symptoms of skin appearance and breast hardness ${ }^{4}$.

\section{Correlation between BCCT.core and physician's opinion and/or patient's opinion}

BCCT.core versus physician

Cardoso et $a l^{6}$ evaluated the validity of the BCCT.core software by a panel of experts. Overall interobserver agreement for the subjective score was fair to moderate $(k=0.40, w k=0.57)$, whereas the concordance level for the objective BCCT.core measurement was much higher $(k=0.86$, wk $=0.90)$. The agreement between the subjective measurement and the BCCT.core was only fair $(k=0.34, w k=$ 0.53 ), but increased to moderate if scale 2 and 3 of the Harris scale were merged to a 3-point scale $(k=0.57, w k=0.72)$. We found on a two-point scale, i.e. satisfactory or non-satisfactory overall cosmetic outcome, a somewhat lower correlation between BCCT.core score and physician scores: 0.39. A possible explanation is that in the YBT the cosmetic evaluation was scored only by the treating physician instead of by a panel that reached consensus.

\section{BCCT.core versus patient}

The correlation between objective measures and PRCO shows reported $k$ values varying from 0.04 to $0.34^{17,18}$, which corresponds to the value of 0.26 found in our study. The different kappa values in the different studies can probably be ascribed to different methods to measure PRCOs. Yu et al. used a conversation with researchers not involved in treatment of patients ${ }^{18}$. Heil et al. used a validated 
patient questionnaire BCTOS (Breast Cancer Treatment Outcome Scale) ${ }^{17}$, but another one than ours

${ }^{12}$. In both questionnaires (BCTOS and ours ${ }^{12}$ ), patients were asked to rate seven items according to symmetry. In the BCTOS the rounded mean of these seven items was used as an overall score, while we compared only the last question in our questionnaire ${ }^{12}$ with the BCCT.core score, since that question dealt with the overall PRCO.

The fact that the PRCO correlated less with the overall BCCT.core score than the physician's opinion, confirms our hypothesis that specific symmetry parameters were more important than others. Furthermore, we found that also other factors such as fibrosis, not directly measured by BCCT.core, influenced PRCO.

\section{Correlation between physicians' and patients' opinion}

Several studies comparing patient with physician's reported overall cosmetic outcome showed various results. In some studies, similar to our study, patients scored their cosmesis and/or normal tissue effects worse than the clinician ${ }^{4,19}$ or photographic assessment ${ }^{19}$, while other studies, showed opposite results ${ }^{20,21}$.

The START trial ${ }^{5}$ also reported on agreement between PRCOs and clinical or photographic assessments of breast specific normal tissue effects. They found wk coefficients of $0.05-0.21$. These lower values might be explained by the difference in questions. For example, in the START trial telangiectasia (clinicians) was correlated with skin changes (patient) which could mean more than only telangiectasia ( $w k=0.08$ at 5 years). Also, in some questions the patient was asked to indicate whether their scoring was influenced by radiotherapy, which is difficult if not impossible to judge by the patient. Another difference with our study was that the photographic assessment was performed by a panel, whilst we used an objective software program to analyse the photographs.

\section{Overall cosmetic scores}

The overall cosmetic outcome in the YBT was worse than published in most other studies. Only Haloua et al. found similar results as we did ${ }^{20}$. However, no data on radiation dose were given in this paper. In the boost versus no boost trial $86 \%$ of the patients had excellent or good score in the no boost group compared to $71 \%$ in the boost group at 3 years ${ }^{2}$, whereas in the YBT these scores were only found in $56-61 \%$, dependent on the scoring method.

Better cosmetic outcome results are also reported by Kelemen et $\mathrm{al}^{22}$ and Hau et $\mathrm{al}^{21}$. Hau et al. found excellent/good cosmesis, scored by physician or patient in $95 \%$ and $93 \%$ in the boost- and no-boostarm respectively) versus $81 \%$ (boost) and $68 \%$ (no boost) according to the BCCT.core software ${ }^{21}$. In this trial the whole breast dose was lower in the boost-arm than in the no-boost-arm. 
A possible explanation for the worse cosmetic outcome results in the YBT is that half of the patient population received a high ( $26 \mathrm{~Gy}$ ) boost. Detailed analysis of the effect of these treatment related factors on overall cosmetic outcome will be performed and presented in a separate paper.

\section{Strengths and limitations}

This study is the largest study reported up till now addressing the question which objective parameters are related to PRCO. In a large subset of patients, three kinds of cosmetic analyses were performed. A limitation of this study is that it comprises only a subset of the total number of patients included in the YBT. This may have several causes, like the relatively short median follow up of 51 months and the usual delay for sending in CRFs. For some patients not all digital photographs were available, or not usable due to quality or technical issues. Since we only analysed quantitative variables, we expect that the missing data did not significantly affect our overall results.

Another important aspect to take into account is that all patients were 50 years or younger. It is thus not clear whether the same correlation exists in elderly patients.

\section{Conclusion}

Patient reported cosmetic outcome is mostly related to the distance from the nipple to the inframammary fold, the length of the breast contour, and by the severity of fibrosis. Patients with higher emotional functioning or better QoL scored their cosmesis better. 
Conflict of interest

None declared.

\section{Acknowledgments}

The data management of the YBT was supported by a grant of the Dutch Cancer Society (CKTO 200313). The analysis of cosmetic outcome in this paper was supported by a Pink Ribbon grant (2011. W004.C94). The French part of the trial was funded by the French Ministry of Health PHRC2009 and PHRC2012 grants.

Further, the authors thank J. Cardoso and M. Cardoso for the use of the BCCT.core software program,

B. Hanbeukers for analysing the majority of digital photographs using the BCCT.core. software, and L. Pronk en R. Muusers for data retrieval.

Also, we acknowledge and thank Jerôme Lemonnier, project leader in France, for coordinating the Young Boost Trial in France and the following for their active participation: M. van Hezewijk, Leiden (NL); M.J.C. van der Sangen Eindhoven (NL); M.C. Stenfert Kroese, Deventer (NL); J.J.Jobsen, Enschede (NL); J.M. Immink, Delft (NL); M.E. Mast, Den Haag (NL); F.M. Gescher, Den Haag (NL); N. Bijker, Amsterdam (NL); J.W.M. Mens, Rotterdam (NL); W.G.J.M. Smit, Leeuwarden (NL); D.H.F. Rietveld, Amsterdam (NL); I. Lecouillard, Rennes (Fr); C Breton-Callu, Bordeaux (Fr); H. Marsiglia, Villejuif (Fr); J. Thariat, Nice (Fr); A. Benyoucef, Rouen (Fr); A. Labib, Saint Cloud (Fr); M. Aumont, Saint Herblain (Fr); P. Bon-temps, Besancon (Fr); C. Le Foll, Lagny (Fr); Y. Belkacemi, Créteil (Fr); O. Chapet, Lyon (Fr); V. Strnad, Erlangen (De). 


\section{References}

1. Bartelink $\mathrm{H}$, Maingon $\mathrm{P}$, Poortmans $\mathrm{P}$, et al. Whole-breast irradiation with or without a boost for patients treated with breast-conserving surgery for early breast cancer: 20-year follow-up of a randomised phase 3 trial. Lancet Oncol 2015;16:47-56..

2. Vrieling $C$, Collette $L$, Fourquet $A$, et al. The influence of the boost in breast-conserving therapy on cosmetic outcome in the EORTC "Boost versus no Boost" Trial. Int J Radiat Oncol 1999;45:677-85.

3. Mukesh MB, Barnett GC, Wilkinson JS, et al. Randomized controlled trial of intensity-modulated radiotherapy for early breast cancer: 5 -year results confirm superior overall cosmesis. J Clin Oncol 2013;31:4488-95.

4. Mukesh MB, Qian W, Wilkinson JS, et al. Patient reported outcome measures (PROMs) following forward planned field-in field IMRT: results from the Cambridge Breast IMRT trial. Radiother Oncol 2014;111:270-5.

5. Haviland JS, Hopwood P, Mills J, Sydenham M, Bliss JM, Yarnold JR. Do Patient-reported Outcome Measures Agree with Clinical and Photographic Assessments of Normal Tissue Effects after Breast Radiotherapy? The Experience of the Standardisation of Breast Radiotherapy (START) Trials in Early Breast Cancer. Clin Oncol 2016:1-9.

6. Cardoso MJ, Cardoso J, Amaral N. Turning subjective into objective: the BCCT.core software for evaluation of cosmetic results in breast cancer conservative treatment. Breast 2007;16:456-61.

7. Fitzal $\mathrm{F}$, Krois $\mathrm{W}$, Trischler $\mathrm{H}$, et al. The use of a breast symmetry index for objective evaluation of breast cosmesis. Breast 2007;16:429-35.

8. Sobin LH, Gospodarowicz MK WC. TNM Classification of Malignant Tumors; 2002.

9. Young J, Badgery-Parker T, Dobbins T, et al. Comparison of ECOG/WHO performance status and ASA score as a measure of functional status. J Pain SymptomManage 2015;49:258-64.

10. Cardoso JS, Cardoso MJ. Towards an intelligent medical system for the aesthetic evaluation of breast cancer conservative treatment. Artif Intell Med 2007;40:115-26.

11. Harris JR, Levene MB, Svensson G, Hellman S. Analysis of cosmetic results following primary radiation therapy for stages I and II carcinoma of the breast. Int J Radiat Oncol 1979;5:257-61.

12. Sneeuw KC, Aaronson NK, Yarnold JR. Cosmetic and functional outcomes of breast conserving treatment for early stage breast cancer. 1. Comparison of patients' ratings, observers' ratings, and objective assessments. Radiother Oncol 1992;25:153-9..

13. Aaronson NK, Ahmedzai S, Bergman B, et al. The European Organization for Research and Treatment for Use in International Clinical Trials in Oncology 1993;85:365-76.

14. Cohen J. Weighted kappa: nominal scale agreement with provision for scaled disagreement or partial credit. Psychol Bull 1968;70:213-20.

15. Christie DRH, O'Brien MY, Christie JA. A comparison of methods of cosmetic assessment in breast conservation treatment. Breast 1996;5:358-67.

16. Brunault $P$, Suzanne I, Trzepidur-Edom $M$, et al. Depression is associated with some patientperceived cosmetic changes, but not with radiotherapy-induced late toxicity, in long-term breast cancer survivors. Psychooncology 2013;22:590-7.

17. Heil J, Dahlkamp J, Golatta $M$, et al. Aesthetics in breast conserving therapy: do objectively measured results match patients' evaluations? Ann Surg Oncol 2011;18:134-8. 
18. Yu T, Eom K-Y. Objective measurement of cosmetic outcomes of breast conserving therapy using BCCT.core. Cancer Res Treat 2015.

19. Haviland JS, Sydenham M, Mills J, Hopwood P, Bliss JM, Yarnold JR. Can patient reported outcome measures replace clinical assessments in breast radiotherapy trials? Radiother Oncol 2012;103:S53.

20. Haloua MH, Krekel NMA, Jacobs GJA, et al. Cosmetic outcome assessment following breastconserving therapy: a comparison between BCCT.core software and panel evaluation. Int J Breast Cancer 2014;2014:1-7. .

21. Hau E, Browne LH, Khanna S, et al. Radiotherapy breast boost with reduced whole-breast dose is associated with improved cosmesis: the results of a comprehensive assessment from the St. George and Wollongong randomized breast boost trial. Int J Radiat Oncol Biol Phys 2012;82:6829.

22. Kelemen G, Varga Z, Lázár G, Thurzó L, Kahán Z. Cosmetic outcome 1-5 years after breast conservative surgery, irradiation and systemic therapy. Pathol Oncol Res 2012;18:421-7. 


\section{Chapter 3}

\section{Predictors for poor cosmetic outcome in patients with early}

stage breast cancer treated with breast conserving therapy: Results of the Young boost trial

Patricia J.A.M. Brouwers*, Erik van Werkhoven*, Harry Bartelink, Alain Fourquet, Claire Lemanski, Judith van Loon, John H. Maduro, Nicola S. Russell, Luc J.E.E. Scheijmans, Dominic A.X. Schinagl, Antonia H. Westenberg, Philip Poortmans, Liesbeth J. Boersma, on behalf of the Young Boost Trial research group

* These authors contributed equally as the first author 


\begin{abstract}
Purpose: In the Young Boost trial (YBT), breast cancer patients $\leq 50$ years of age, treated with breast conserving therapy (BCT) were randomized between a $26 \mathrm{~Gy}$ boost dose and a $16 \mathrm{~Gy}$ boost dose, with local recurrence as primary and cosmetic outcome (CO) as secondary endpoint. Data of the YBT was used to investigate which factors are related with worse cosmetic outcome after BCT.

Methods: From 2004 to 2011, 2421 cT1-2NO-2a breast cancer patients were randomized. CO was scored subjectively by the patient and physician, and objectively using BCCT.core: at baseline, one and four years after treatment. Associations between potential risk factors for worse cosmetic outcome, based on the objective BCCT.core, were investigated using a proportional odds model.

Results: At four years, CO was significantly better in the standard boost group for all three scoring methods (satisfied CO $\pm 65 \%$ vs $55 \%$ ). A photon boost, high boost dose, poor cosmesis before radiation therapy, large boost volume and adjuvant chemotherapy significantly deteriorated CO.

Conclusion: Important risk factors for worse $\mathrm{CO}$ were the use of a photon boost instead of an electron boost, a high boost dose, cosmesis at baseline, adjuvant chemotherapy and boost volume. These results can be used to define strategies aimed at improving $\mathrm{CO}$.
\end{abstract}




\section{Introduction}

In women with early breast cancer treated with breast-conserving surgery (BCS), whole breast radiation therapy (RT) reduces the risk of local recurrence at 5 years from $26 \%$ to $7 \%^{1}$. The EORTC "boost versus no boost" trial showed that an additional boost of $16 \mathrm{~Gy}$ to the tumour bed reduces the risk for local failure by a factor of 2 , with an increased incidence of moderate/severe fibrosis as negative side effect ${ }^{2}$. However, after 10 years follow up, the risk of local failure remained unacceptably high, in the younger patients, even after a boost, with a risk of $13.5 \%$ in patients $\leq 40$ years, and of $8.7 \%$ in patients $41-50$ years $^{3}$. Therefore, in 2004, the Young Boost trial (YBT) was launched (NCT00212121) with the primary aim to investigate whether a higher boost dose of 26 Gy to the tumour bed would further reduce local recurrence rate in these young patients with cosmetic outcome as secondary endpoint.

Several risk factors for deterioration of the cosmetic outcome have been described in literature, for example breast size $e^{4,5}$, tumour size $e^{6,7}$, excision volume $e^{6,7}$, tumour location ${ }^{5-7}$, post-operative complications $^{4,5}$, boost volume ${ }^{8}$, a photon boost ${ }^{7,9}$, total dose ${ }^{10}$ and dose $\max ^{8,9,11}$. However, no data is available concerning a boost dose as high as 76 Gy EQD2, which makes the YBT unique. Moreover, in order to be able to improve cosmetic outcome, we need to continue to update the knowledge of risk factors for cosmetic outcome with data derived from the most current literature.

It was decided by the independent data monitoring committee that the primary endpoint (i.e. local failure) should not be analysed yet. However, they recommended that the cosmetic outcome, which was a secondary endpoint, could be analysed by treatment arm now that up to 4 years of follow-up is available. Previously, we reported that the distance from nipple to inframammary fold, the length of the breast contour and the severity of fibrosis were associated with patient reported outcome in the $\mathrm{YBT}^{12}$. The primary aim of this paper is to report on the cosmetic outcome in the YBT; the secondary aim is to define risk factors for worse cosmetic outcome in this patient population, based on the objective BCCT.core.

\section{Patients \& Methods}

\section{Patient population and treatment}

Patients younger than 51 years with non-metastatic, histological proven invasive breast cancer, pT12NO-2 $\mathrm{a}^{13}$ were eligible for the trial when fulfilling the following inclusion criteria: ECOG performance scale $\leq 2$; wide local excision (WLE); microscopically complete (no tumour on ink) or focally involved 
(defined as: "tumour (ductal carcinoma in situ or invasive carcinoma) on ink in an area of less than 4 $\mathrm{mm}^{\prime \prime}$ ) resection; sentinel lymph node biopsy and/or axillary lymph node dissection; no primary systemic treatment; no previous history of malignant disease, except adequately treated carcinoma in situ of the cervix or basal cell carcinoma of the skin. Exclusion criteria were: residual microcalcifications on mammogram; histological other than invasive adenocarcinoma; in situ carcinoma of the breast without invasive tumour; multicentric tumours and multifocal tumours excised using multiple excisions; bilateral invasive breast cancer and concurrent pregnancy. More information can be found at https://clinicaltrials.gov/show/NCT00212121.

Patients were randomized to receive a standard $16 \mathrm{~Gy}$ or a high $26 \mathrm{~Gy}$ boost to the tumour bed after 50 Gy whole breast irradiation, given in 2 Gy fractions. Other fractionation schemes, including simultaneous integrated boost (SIB) techniques were allowed as well, as long as the biological equivalent dose (EQD2), calculated with an $\alpha / \beta$ of 10 for tumour control, was similar. The overall treatment time was kept constant in both randomization arms, i.e. 6.5-7 weeks (see supplementary file for more extensive information concerning the RT protocol). RT had to start within 10 weeks after surgery. In case adjuvant chemotherapy was given immediately after surgery, RT should start within 6 months after surgery and within 6 weeks after the last cycle of chemotherapy. In case endocrine treatment was planned, this was recommended to start after completion of the RT. Stratification factors were age $(<v s>40 \mathrm{yrs}$.), pathological tumour size $(<v s>3 \mathrm{~cm})$, oestrogen receptor status, nodal status, interstitial/external boost and institute. Patients were stratified at the time of randomization; treatment was assigned using a "randomization by minimisation" technique ${ }^{14}$.

The study was centrally approved by the medical ethical committee of the Netherlands Cancer Institute and by the local medical ethical committees. All patients gave their written informed consent to participate.

\section{Recording of fibrosis and cosmetic outcome}

Cosmetic outcome and fibrosis were scored at baseline, i.e. after surgery but prior to start of RT, at 1 year, 4, 7 and 10 years of follow up (FU). Standardized digital photographs were taken at the same time-points.

The presence of fibrosis (whole breast and specifically in the boost area) was scored by the physician on a 4-point scale: none, minor, moderate or severe.

Cosmetic outcome was scored according to the following three scoring systems: 
BCCT.core software ${ }^{15,16}$ : digital photographs in anterior-posterior view were analysed using the BCCT.core software program. Pre-determined points were designated by the examiner, followed by an automatic calculation of an overall cosmetic score: excellent, good, fair or poor (score 1 to 4; higher score means worse outcome). This score is based on symmetry, skin colour and scar visibility.

Physician's score. Physicians scored cosmetic outcome using the Harris scale ${ }^{17}$ : excellent, good, fair or poor, indicated as score 1 to 4 respectively.

Patient's questionnaire. Patients' satisfaction with the cosmetic outcome was scored using a validated patient's questionnaire developed by Sneeuw et $\mathrm{al}^{18}$ : very satisfied, satisfied, not dissatisfied, dissatisfied or very dissatisfied (score 1 to 5 respectively).

For the analyses of crude percentages, the scores very satisfied or satisfied and good or excellent were grouped as 'satisfactory'.

\section{Analysis of risk factors for fibrosis and cosmetic outcome}

The following risk factors, scored on the Case Report Forms, were investigated:

$R T$ related risk factors: dose to the tumour bed; irradiated boost volume (per $10 \mathrm{cc}$ ), defined as the volume receiving more than $95 \%$ of the boost dose for external photon irradiation, and within $85 \%$ of the boost dose for electron and interstitial irradiation; photon boost versus electron boost; Simultaneous Integrated Boost (SIB) versus sequential boost; energy used for whole breast irradiation (WBI) and the use of CT-scan for planning.

Systemic therapy related factors: adjuvant chemotherapy, adjuvant endocrine therapy.

Surgery related factors: excision volume (per $10 \mathrm{cc}$ ); post-operative complications and seroma, scored as yes, no, or unknown. Postoperative complications were defined as the presence of infection and/or hematoma of breast and/or axilla. Oedema was not considered as a complication. Seroma was analysed separately from post-operative complications, as we assumed there might be a correlation with oncoplastic surgery.

Tumour related factors: tumour location (lateral tumour location vs. central and medial/upper tumour location vs. central) (supplementary figure).

Patient characteristics: age (per year) and cosmetic score at baseline. 


\section{$\underline{\text { Statistical analysis }}$}

The percentages of patients with satisfactory cosmetic scores in the high- and standard boost group were compared at baseline, 1 year and 4 years with Fisher's exact test. Associations between potential risk factors and cosmetic outcome, measured by BCCT.core, were assessed with a proportional odds model, in order to treat the cosmetic outcome as a variable with ordered categories. An important assumption of the proportional odds model is that the association between each pair of outcome groups is the same, so that for example the comparison between a score of 1 (=Excellent) versus a score of 2 (=Good), 3 (=Fair) or 4 (=Poor), and the comparison of 1 or 2 versus 3 or 4 can be modelled by the same parameter. The assumption was verified by calculation of linear predictions from a logit model, used to model the probability that the outcome is greater than or equal to a given value (for each cosmetic outcome level). These were compared between categories of one predictor variable at a time, and no great differences were observed.

Both the number of patients with moderate and severe fibrosis, and of patients with severe fibrosis at baseline, 1 year, and 4 years was calculated as a percentage of the total number of patients with an assessment and compared by arm using Fisher's test. Time to fibrosis was calculated from randomization to first reported occurrence of moderate or severe fibrosis. Patients with no or only minor fibrosis were censored at last follow-up. Risk factors for moderate or severe fibrosis were analysed with multivariable Cox proportional hazards models.

\section{Results}

Between 2004 and 2011, 2421 breast cancer patients were included in 32 institutes (18 from The Netherlands, 13 from France and 1 from Germany). 1211 patients were randomized to receive a standard $16 \mathrm{~Gy}$ boost and 1210 to receive a $26 \mathrm{~Gy}$ boost. Baseline patient characteristics were similar in both groups with the exception of boost technique (table 1). Median age was 45 years (range 1951), $19 \%$ was younger than 40 years of age. $72 \%$ of patients had a T1 tumour and $28 \%$ of patients had a T2 tumour. Median FU at the time of this analysis was 51 months. 46 patients did not comply with the inclusion criteria (supplementary file table A). All patients with available and evaluable digital photographs were included in the analysis.

At baseline, 1657 evaluable digital photographs were available of the study population. At one year, evaluable digital photographs were available from 1455 patients, of whom 1276 also had an evaluable photograph at baseline. At four years, 684 digital photographs were evaluable of patients including a photograph at baseline (Fig. 1). 


\begin{tabular}{|c|c|c|c|c|}
\hline \multirow[b]{2}{*}{ Patients } & \multicolumn{2}{|c|}{ Randomization treatment } & \multirow[b]{2}{*}{$\begin{array}{c}\text { Total } \\
\mathrm{N}=2421\end{array}$} & \multirow[b]{2}{*}{$P$ value } \\
\hline & $\begin{array}{c}16 \mathrm{~Gy} \text { boost } \\
\mathrm{N}=1211\end{array}$ & $\begin{array}{c}26 \text { Gy boost } \\
N=1210\end{array}$ & & \\
\hline $\begin{array}{l}\text { Age at randomization } \\
\text { Median age in years (range) }\end{array}$ & $45(19-51)$ & $45(21-51)$ & $45(19-51)$ & 0.94 \\
\hline $\begin{array}{l}\text { Age (yrs) at randomization } \\
\text { (grouped) } \\
19-24 \\
25-29 \\
30-39 \\
40-44 \\
45-59 \\
50-51\end{array}$ & $\begin{array}{c}1(0 \%) \\
15(1 \%) \\
219(18 \%) \\
348(29 \%) \\
516(43 \%) \\
112(9 \%)\end{array}$ & $\begin{array}{c}2(0 \%) \\
13(1 \%) \\
223(18 \%) \\
351(29 \%) \\
512(42 \%) \\
109(9 \%)\end{array}$ & $\begin{array}{c}3(0 \%) \\
28(1 \%) \\
442(18 \%) \\
699(29 \%) \\
1028(43 \%) \\
221(9 \%)\end{array}$ & 0.99 \\
\hline $\begin{array}{l}\text { Tumour location } \\
\text { Central/lower } \\
\text { Lateral } \\
\text { Medial/upper } \\
\text { NA }\end{array}$ & $\begin{array}{c}275(23 \%) \\
606(50 \%) \\
323(27 \%) \\
7\end{array}$ & $\begin{array}{l}293(24 \%) \\
594(49 \%) \\
317(26 \%) \\
6\end{array}$ & $\begin{array}{c}568(24 \%) \\
1200(50 \%) \\
640(27 \%) \\
13\end{array}$ & 0.69 \\
\hline $\begin{array}{l}\text { Pathological largest diameter }(\mathrm{mm}) \\
\mathrm{N} \\
\text { Median (range) }\end{array}$ & $\begin{array}{c}1205 \\
15(1-49)\end{array}$ & $\begin{array}{c}1201 \\
15(1-95)\end{array}$ & $\begin{array}{c}2406 \\
15(1-95)\end{array}$ & 0.73 \\
\hline $\begin{array}{l}\text { Largest diameter }(\mathrm{mm}) \text { (grouped) } \\
>20 \mathrm{~mm} \\
\leq 20 \mathrm{~mm} \\
\text { NA }\end{array}$ & $\begin{array}{c}345(29 \%) \\
860(71 \%) \\
6\end{array}$ & $\begin{array}{c}327(27 \%) \\
874(73 \%) \\
9\end{array}$ & $\begin{array}{c}672(28 \%) \\
1734(72 \%) \\
15\end{array}$ & 0.47 \\
\hline $\begin{array}{l}\text { Excision volume }(\mathrm{ml}) \\
\mathrm{N} \\
\text { Median (range) }\end{array}$ & $\begin{array}{c}1101 \\
112(0-3150)\end{array}$ & $\begin{array}{c}1120 \\
105(0-4462)\end{array}$ & $\begin{array}{c}2221 \\
108(0-4462)\end{array}$ & 0.19 \\
\hline $\begin{array}{l}\text { Final margin status } \\
\text { Complete } \\
\text { Focally incomplete excision }\end{array}$ & $\begin{array}{c}1180(97 \%) \\
31(3 \%)\end{array}$ & $\begin{array}{c}1182(98 \%) \\
28(2 \%)\end{array}$ & $\begin{array}{c}2362(98 \%) \\
59(2 \%)\end{array}$ & 0.79 \\
\hline $\begin{array}{l}\text { Postoperative complications } \\
\text { No } \\
\text { Yes } \\
\text { NA }\end{array}$ & $\begin{array}{c}818(68 \%) \\
335(28 \%) \\
58(5 \%)\end{array}$ & $\begin{array}{c}835(69 \%) \\
309(26 \%) \\
66(5 \%)\end{array}$ & $\begin{array}{c}1653(68 \%) \\
644(27 \%) \\
124(5 \%)\end{array}$ & 0.29 \\
\hline $\begin{array}{l}\text { Endocrine therapy } \\
\text { No } \\
\text { Yes* } \\
\text { NA }\end{array}$ & $\begin{array}{c}483(40 \%) \\
667(55 \%) \\
61(5 \%)\end{array}$ & $\begin{array}{c}491(41 \%) \\
650(54 \%) \\
69(6 \%)\end{array}$ & $\begin{array}{c}974(40 \%) \\
1317(54 \%) \\
130(5 \%)\end{array}$ & 0.64 \\
\hline $\begin{array}{l}\text { Chemotherapy } \\
\text { No } \\
\text { Yes } \\
\text { NA }\end{array}$ & $\begin{array}{c}441(36 \%) \\
748(62 \%) \\
22(2 \%)\end{array}$ & $\begin{array}{c}458(38 \%) \\
719(59 \%) \\
33(3 \%)\end{array}$ & $\begin{array}{c}899(37 \%) \\
1467(61 \%) \\
55(2 \%)\end{array}$ & 0.37 \\
\hline $\begin{array}{l}\text { Timing of chemotherapy } \\
\text { Prior to RT } \\
\text { During RT } \\
\text { After RT } \\
\text { NA }\end{array}$ & $\begin{array}{c}364(49 \%) \\
10(1 \%) \\
370(49 \%) \\
4(1 \%) \\
\end{array}$ & $\begin{array}{c}357(50 \%) \\
2(0 \%) \\
356(50 \%) \\
4(1 \%)\end{array}$ & $\begin{array}{c}721(49 \%) \\
12(1 \%) \\
726(49 \%) \\
8(1 \%)\end{array}$ & 0.08 \\
\hline $\begin{array}{l}\text { Radiation quality } \\
\text { Cobalt } 60 \\
\text { X-ray beams }\end{array}$ & $\begin{array}{c}0(0 \%) \\
1196(99 \%)\end{array}$ & $\begin{array}{c}3(0 \%) \\
1180(98 \%)\end{array}$ & $\begin{array}{c}3(0 \%) \\
2376(98 \%)\end{array}$ & 0.12 \\
\hline
\end{tabular}




\begin{tabular}{lcccc}
\hline NA & $15(1 \%)$ & $27(2 \%)$ & $42(2 \%)$ & \\
\hline$X$-ray energy (MV) WBI & & & & 0.95 \\
$N$ & 1086 & 1055 & 2141 & \\
Median (range) & $6(4-25)$ & $6(4-25)$ & $6(4-25)$ & 0.08 \\
\hline Irradiated boost volume (cc) & & & & \\
$N$ & 1125 & 1106 & 2231 & \\
Median (range) & $135(0-1125)$ & $130(0-1308)$ & $132(0-1308)$ & \\
\hline Boost technique & & & & \\
Electrons & $265(22 \%)$ & $214(18 \%)$ & $479(20 \%)$ & \\
Cobalt60 & $6(0 \%)$ & $4(0 \%)$ & $10(0 \%)$ & \\
Photons & $882(73 \%)$ & $895(74 \%)$ & $1777(73 \%)$ & \\
Interstitial boost & $10(1 \%)$ & $13(1 \%)$ & $23(1 \%)$ & \\
Other/NA & $48(4 \%)$ & $84(7 \%)$ & $132(5 \%)$ & \\
& & & & \\
\hline SIB & & & & \\
No & $784(65 \%)$ & $768(65 \%)$ & $1552(64 \%)$ & \\
Yes & $416(34 \%)$ & $416(34 \%)$ & $832(34 \%)$ & \\
NA & $11(1 \%)$ & $26(2 \%)$ & $37(2 \%)$ & \\
\hline Planning CT ${ }^{* *}$ & & & & \\
No & $286(24 \%)$ & $291(24 \%)$ & $577(24 \%)$ & \\
Yes & $917(76 \%)$ & $902(75 \%)$ & $1819(75 \%)$ & \\
NA & $8(1 \%)$ & $17(1 \%)$ & $25(1 \%)$ & \\
\hline \hline
\end{tabular}

Table 1. Patient and treatment characteristics at baseline.

Abbreviations: $\mathrm{NA}=$ not applicable; $\mathrm{RT}=$ radiotherapy; $\mathrm{WBI}=$ whole breast irradiation; $\mathrm{MV}=$ megavolt; SIB = simultaneous integrated boost.

* in $85 \%$ Tamoxifen

** If 3D planning and 3D delineation was performed

At baseline, cosmetic score was similar in both patient groups independent of the scoring-methods. In $90 \%$ cosmetic score was satisfactory based on BCCT.core. According to the physician or patient, satisfactory scores were $80 \%$ or a little less than $70 \%$ respectively, at baseline. At 4 years, cosmetic outcome was significantly worse than at baseline in both treatment arms, for all three scoringmethods. The cosmetic outcome was better in the standard boost group compared to the high boost group for all three scoring-methods: according to BCCT.core $67 \%$ of patients had satisfactory cosmesis in the standard boost, versus $55 \%$ in the high boost group $(p=0.0009)$. For scores by the physicians these numbers were $65 \%$ and $52 \%(p<0.0001)$, and for patients $63 \%$ and $53 \%(p=0.0007)$, respectively (Table 2). 


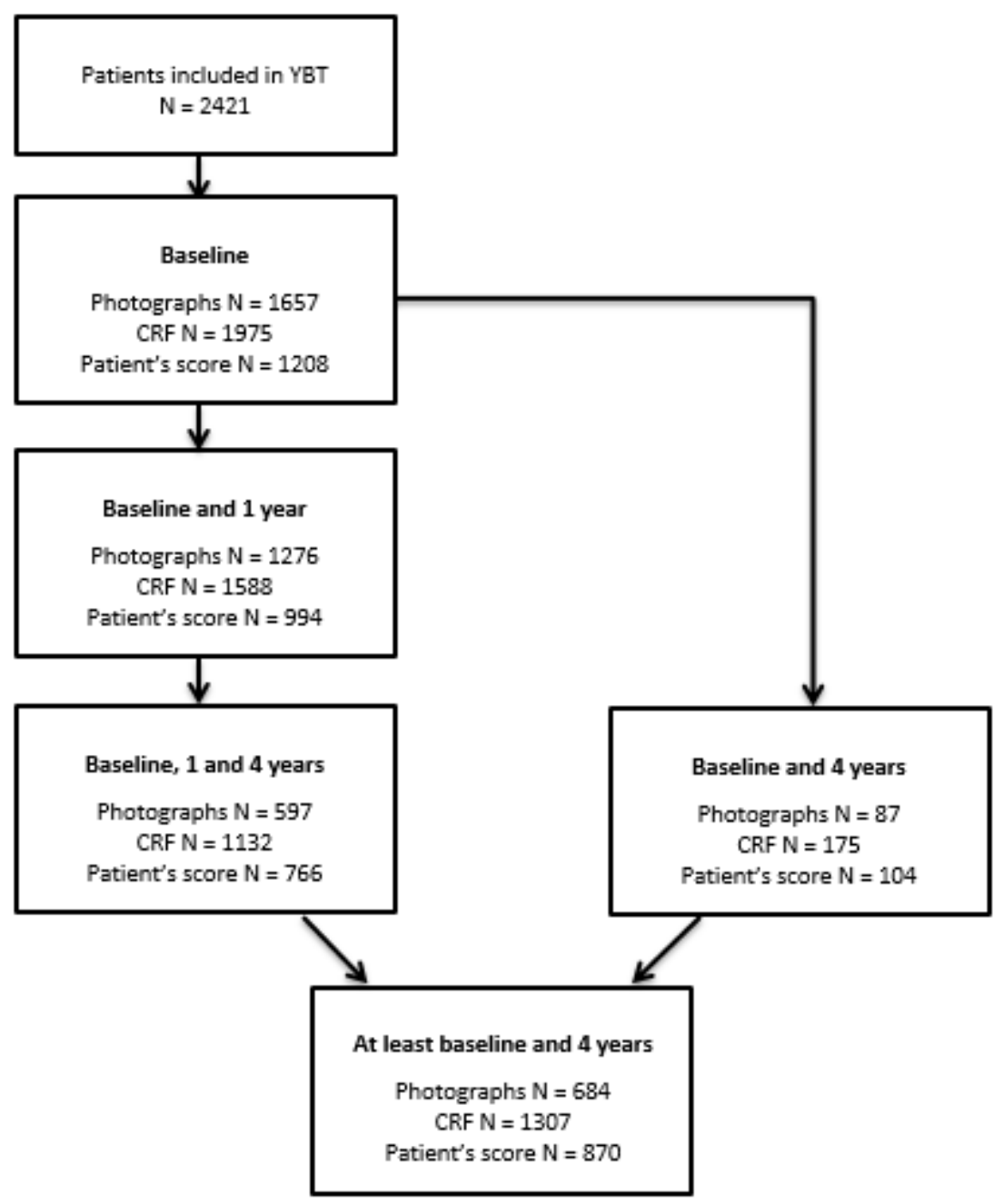

Figure 1. Flow diagram of available and evaluable digital photographs per July 2014, and completed Case Report Form (CRF) and completed patient questionnaires of all institutes per February 2017.

At 4 years, the physician scored moderate or severe fibrosis in the boost area in 159 patients (19\%) in the standard boost group versus $332(39 \%)$ in the high boost group $(p<0.0001)$. Severe fibrosis was scored in the boost area in $25(3 \%)$ and 89 (11\%) patients in the standard and high boost group, respectively $(\boldsymbol{p}<0.0001)$ (Table 2 ). Also, when fibrosis was calculated as a percentage of the evaluable patients at the three time points separately, the difference between the arms remained significant (Table 2).

The cumulative incidence of moderate or severe fibrosis in the boost area at 4 years was $27 \%(95 \% \mathrm{Cl}$ $24 \%-30 \%)$ in the $s$ boost group versus $45 \%$ (95\% Cl $42-47 \%$ ) in the high boost group ( $<<0.0001$, Fig. 2 ). 


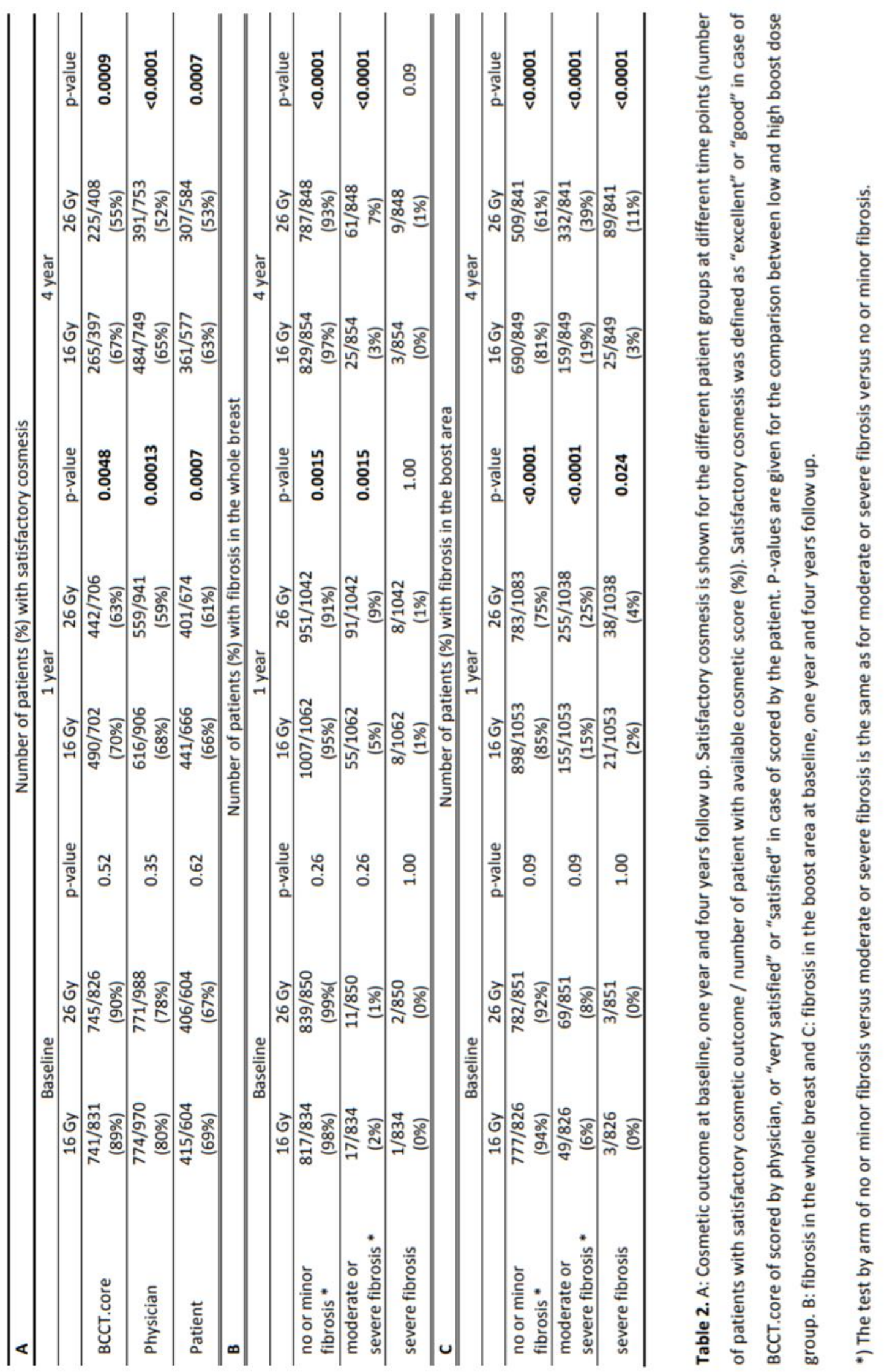




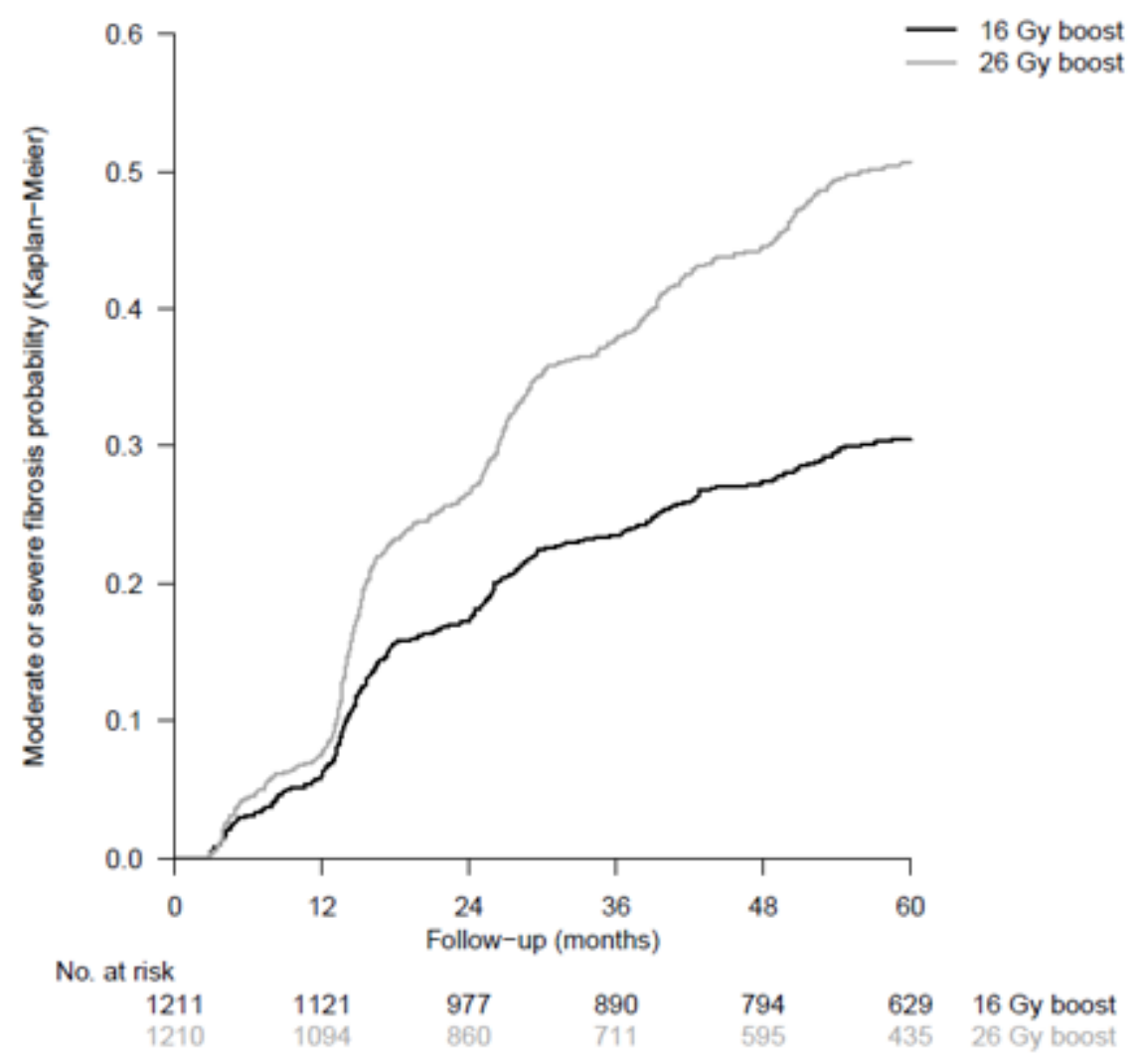

Figure 2. Cumulative incidence of moderate or severe fibrosis in the boost area

There was a low correlation between cosmetic outcome and fibrosis: Spearman's rank correlation 0.29 $(p<0.0001)$.

Significant risk factors in the multivariable model for worse cosmetic outcome according to BCCT.core score at 4 years were a photon boost (odds ratio 1.98 compared to electrons), a high boost dose (odds ratio 1.82 compared to standard boost), cosmesis at baseline (odds ratio 1.80 per BCCT.core category), adjuvant chemotherapy (odds ratio 1.58 yes vs. no) and boost volume (odds ratio 1.04 per $10 \mathrm{cc}$ ). The following factors were not significantly associated with cosmetic outcome: age, tumour location, adjuvant endocrine therapy, radiation energy $\mathrm{WBI}$, use of $\mathrm{CT}$ for planning, excision volume per $10 \mathrm{cc}$, postoperative complications, seroma or whether the boost was given simultaneously (SIB) versus sequentially (Table 3). Significant risk factors for moderate or severe fibrosis were cosmesis at baseline (HR 1.20 per BCCT.core category), a high boost dose (HR 2.00), age (HR 1.02 per year older), adjuvant chemotherapy (HR 1.25 yes vs. no), radiation energy WBI (HR 1.03 per MV), irradiated boost volume (HR 1.01 per 10cc) and a simultaneous integrated boost (HR 1.40 yes vs. no) (Table 4). 


\begin{tabular}{lccc}
\hline & Odds ratio & $95 \% \mathrm{Cl}$ & P value \\
\hline Cosmesis at baseline & 1.80 & $1.40-2.33$ & $<0.0001$ \\
\hline High boost dose & 1.83 & $1.33-2.54$ & $<0.0001$ \\
\hline Age (per year) & 0.99 & $0.96-1.02$ & 0.557 \\
\hline Lateral tumour location vs. central & 0.70 & $0.47-1.03$ & 0.073 \\
\hline Medial/upper tumour location vs. & 0.83 & $0.53-1.31$ & 0.429 \\
central & 1.53 & $1.04-2.27$ & 0.032 \\
\hline Adjuvant chemotherapy & 1.16 & $0.80-1.69$ & 0.429 \\
\hline Adjuvant endocrine therapy & 1.05 & $0.97-1.13$ & 0.232 \\
\hline Photon energy of WBI & 1.04 & $1.02-1.05$ & $<0.0001$ \\
\hline Boost volume per 10 cc* & 1.98 & $1.31-3.01$ & $<0.0001$ \\
\hline Boost technique (photon vs. electron) & 0.96 & $0.63-1.46$ & 0.837 \\
\hline SIB vs. sequential boost & 1.52 & $0.93-2.50$ & 0.097 \\
\hline Seroma & 1.15 & $0.78-1.70$ & 0.478 \\
\hline Postoperative complications & 1.00 & $1.00-1.01$ & 0.448 \\
\hline Excision volume per 10 cc & 0.90 & $0.62-1.31$ & 0.585 \\
\hline Use of planning CT & & & \\
\hline \hline
\end{tabular}

Table 3. Results of the multivariable proportional odds model for cosmetic outcome based on $\mathrm{BCCT}$.core. Odds ratio $>1$ means that the factor as a negative impact on cosmetic outcome, $<1 \mathrm{a}$ positive impact.

* The irradiated boost volume is defined as the volume receiving more than $95 \%$ of the boost dose for external photon irradiation, and within $85 \%$ of the boost dose for electron and interstitial irradiation.

$\mathrm{WBI}=$ whole breast irradiation. $\mathrm{SIB}=$ simultaneous integrated boost.

\section{Discussion}

The results of this analysis demonstrate that, as expected, a high boost causes a less satisfactory cosmetic outcome. At 4 years follow up, the percentage of patients with a satisfactory cosmetic outcome was about $10 \%$ lower in the high boost group compared to the standard boost group, whichever scoring method (BCCT.core, physician, or patient herself) was used. Also, in the high boost 


\begin{tabular}{lccc}
\hline \hline & $\mathrm{HR}$ & $95 \% \mathrm{Cl}$ & $\mathrm{P}$ value \\
\hline \hline Cosmesis at baseline & 1.20 & $1.06-1.35$ & $\mathbf{0 . 0 0 3}$ \\
\hline High boost dose & 2.00 & $1.71-2.35$ & $<0.0001$ \\
\hline Age at randomization & 1.02 & $1.01-1.04$ & $\mathbf{0 . 0 0 5}$ \\
\hline Lateral tumour location vs. central & 0.98 & $0.80-1.19$ & 0.081 \\
\hline $\begin{array}{l}\text { Medial/upper tumour location vs. } \\
\text { central }\end{array}$ & 1.16 & $0.94-1.44$ & 0.17 \\
\hline Adjuvant chemotherapy & 1.25 & $1.04-1.51$ & $\mathbf{0 . 0 1 7}$ \\
\hline Adjuvant endocrine therapy & 0.97 & $0.81-1.15$ & 0.72 \\
\hline Photon energy of WBI & 1.03 & $1.01-1.06$ & $\mathbf{0 . 0 0 7}$ \\
\hline Boost volume per 10 cc* & 1.01 & $1.01-1.02$ & $<0.0001$ \\
\hline Boost technique (photon vs. electron) & 1.13 & $0.90-1.40$ & 0.30 \\
\hline SIB vs. sequential boost & 1.40 & $1.16-1.71$ & $\mathbf{0 . 0 0 0 6}$ \\
\hline Seroma & 1.19 & $0.96-1.47$ & 0.11 \\
\hline Postoperative complications & 1.05 & $0.87-1.27$ & 0.62 \\
\hline Excision volume per 10 cc & 1.00 & $1.00-1.00$ & 0.28 \\
\hline Use of planning CT & 0.89 & $0.73-1.10$ & 0.28 \\
\hline \hline
\end{tabular}

Table 4. multivariable model of time to moderate or severe fibrosis in the boost area.

* The irradiated boost volume is defined as the volume receiving more than $95 \%$ of the boost dose for external photon irradiation, and within $85 \%$ of the boost dose for electron and interstitial irradiation.

$\mathrm{WBI}=$ whole breast irradiation. $\mathrm{SIB}=$ simultaneous integrated boost.

group twice as much moderate or severe fibrosis was scored at 4 years. The multivariable model showed that other important risk factors for worse cosmetic outcome were the use of a photon boost, cosmesis at baseline, adjuvant chemotherapy and boost volume. It is important to note that we have reported the estimate of the effect of the boost volume as a continuous variable per $10 \mathrm{cc}$. This means that the odds ratio holds for every increase of $10 \mathrm{cc}$. The odds ratio is 1.48 if the boost volume is considered per $100 \mathrm{cc}$. 
Risk factors for moderate or severe fibrosis consisted of the same risk factors as for worse cosmetic outcome with the exception of a photon boost and supplemented with age, photon energy of WBI en a simultaneous integrated boost technique.

Although a worse cosmetic outcome was expected for the high boost arm, we surprisingly also observed a somewhat worse cosmetic outcome in the standard boost arm, compared to the identical $16 \mathrm{~Gy}$ boost arm in the former boost versus no-boost trial ${ }^{10}$. In the latter trial, the panel evaluation at 3 years showed that $71 \%$ of patients in the boost group had an excellent or good global result, which is better than the $65 \%$ satisfactory score by the physicians that we found in the $16 \mathrm{~Gy}$ boost arm. There are several possible explanations for this difference. First, in the majority of cases in the boost versus no-boost trial, the boost dose was given with electrons $(74.9 \%)^{7}$; whereas a photon boost was the most important risk factor in our model. Second, in the YBT only the treating physician scored the cosmesis, in contrast to the boost vs no-boost trial, where cosmetic outcome was scored by a panel. Third, in the YBT timing of scoring was one year later (at four instead of three years follow up); the boost vs. no-boost trial already showed that asymmetry progressed over years ${ }^{7}$. Fourth, in the YBT, a larger amount of patients underwent chemotherapy. In the boost no-boost only $10 \%$ of patients received chemotherapy, in the YBT this percentage was $60 \%$ and chemotherapy was identified as a risk factor for worse cosmetic outcome in our model. Finally, also the boost volume was different. Al Uwini et al already showed an enlargement of boost volumes by using a planning $\mathrm{CT}^{19}$. He recalculated the boost volumes of the boost versus no-boost trial and showed that the volume of the $95 \%$ dose level was larger in the YBT. Surprisingly, use of a planning CT was not an independent risk factor in our model, but there might be interaction with the volume variable.

Previous studies found various risk factors for worse cosmetic outcome or fibrosis. Cosmetic outcome and fibrosis are both late toxicity endpoints and are probably associated with each other, but show different progression in time. Where fibrosis is most progressive in the first three to four years ${ }^{9}$, cosmetic deterioration progresses further over the years, also resulting from increasing asymmetry following more pronounced changes in the non-treated breast with ageing ${ }^{7}$. The results in literature are difficult to interpret due to different outcome measures including fibrosis and cosmetic outcome (automatic photograph based, patient score, panel or physician score) and different duration of follow up. Nevertheless, all various risk factors can be brought together to some overarching risk factors: 1 . Dose homogeneity (IMRT ${ }^{20}, \operatorname{Dmax}^{8,9,11}, \mathrm{~V} 55 \mathrm{~Gy}^{11}, \mathrm{~V} 110^{21}, \mathrm{~V} 107^{4}$, breast size ${ }^{4,5}$, prone/supine $\left.{ }^{22}\right) ; 2$. Total dose (hypofractionation ${ }^{23,24}$, boost no-boost ${ }^{10}$, Young Boost); 3. Boost volume ${ }^{8}$ (excision volume $^{6,7}$, tumour size ${ }^{6,7}$, photon boost ${ }^{7,9}$, re-excision ${ }^{25}$, time between surgery and RT, oncoplastic surgery ${ }^{26}$ ) and 4. Baseline cosmesis (excision volume $e^{6,7}$, tumour size ${ }^{6}$, location of tumour ${ }^{5-7}$, post-operative 
complications $\left.^{4,5}\right)$. Further, adjuvant chemotherapy might result in worse cosmesis ${ }^{6,25,27}$. However, nowadays, many patients receive primary chemotherapy and one can assume this beneficially influences cosmetic result by decreasing tumour size, resulting in smaller excision volumes (better baseline cosmesis).

We were somewhat surprised to find SIB as a risk factor for moderate or severe fibrosis, as several planning studies showed dosimetric advantage ${ }^{28}$. To our knowledge, only the group of Groningen published data concerning fibrosis in a large cohort of breast cancer patients treated with a photon SIB ${ }^{11,25}$. They found moderate or severe fibrosis in maximal $13.4 \%$ of patients, compared to the $22 \%$ (data not shown) we found in our standard boost arm (SIB), but they did not compare it with sequential boost results. One explanation might be that the fraction size to the boost volume was higher with the SIB than with the sequential boost, resulting in a higher EQD2 (67.6 vs 66 Gy, and 78.5 Gy vs $76 \mathrm{~Gy}$ for an $\alpha / \beta$ ratio of $4 \mathrm{~Gy}$, and $68.2 \mathrm{~Gy}$ vs $66 \mathrm{~Gy}$ and $79.5 \mathrm{~Gy}$ vs $76 \mathrm{~Gy}$ vs for an $\alpha / \beta$ ratio of 3 Gy.

Unfortunately, we did not score whether oncoplastic surgery had been performed. The obvious aim of oncoplastic surgery is to improve cosmetic outcome. However, after oncoplastic breast surgery the definition of the tumour bed could be more difficult, because of large mammary gland translations, rotations or excisions. Therefore, tumour bed delineation after oncoplastic surgery will be difficult, especially without surgical clips $^{29}$, which can lead to larger boost volumes ${ }^{30}$. Close collaboration between surgeon and radiation oncologist could lead to a reliable, compact boost volume after oncoplastic surgery (mark lumpectomy cavity, then approximate lumpectomy cavity, then apply oncoplastic manoeuvres). The challenge for the future is to find an accurate balance between the extent of oncoplastic surgery and the following uncertainties for the radiation oncologist ${ }^{31}$.

It could have been interesting to analyse the impact of the timing of chemotherapy on cosmetic outcome. We tried to analyse this in the multivariable model by putting chemotherapy into the model as a variable with three categories: chemotherapy before RT, after RT and no chemotherapy at all. This showed that compared to no chemotherapy at all, chemotherapy before RT was significantly associated with worse cosmetic outcome, but not if the chemotherapy was given after RT (results not shown). In order to clarify this discrepancy, we looked within the subgroup of patients with chemotherapy. In that subgroup, there was no difference between before and after, whether we corrected for the other clinical variables in the model or not. Therefore, we believe that we do not have sufficient power to draw valid conclusions about the impact of the timing of chemotherapy. 
The Young Boost Trial is a large international randomized trial and by our knowledge the only trial to investigate the influence of such a high boost dose (EQD2 76 Gy) on cosmetic outcome. Nevertheless, there are some limitations to mention. First of all, we were unable to test all the now known risk factors, such as for example smoking and breast size, since these factors were not known during the design of the YBT. Further, as we described in the methods section, the study was designed with an $\alpha / \beta$ of 10 for tumour control, which was a logical assumption at that time. However, the START trials has shown an $\alpha / \beta$ value for locoregional relapse of $3.5 \mathrm{~Gy}^{23}$.The results of the YBT provide better perception of the risk factors for worse cosmetic outcome. These data therefore provide valuable tools when developing a strategy to improve cosmetic outcome. Since boost dose was one of the most important risk factors predicting poor cosmetic outcome, and local control has increased considerably in the last decade ${ }^{32,33}$, we advise to critically re-evaluate the indication for a (high) boost. Whenever a boost is indicated, an electron boost might be preferred, on the condition that the boost volume is delineated (instead of virtual simulation). Further, the size of the boost volume should be limited as much as possible, by using all available pre- and post-operative data ${ }^{31,34}$. How to take into account baseline cosmetic score is however puzzling: one may argue that oncoplastic surgery will improve cosmetic outcome, since a good baseline cosmesis is correlated with a better cosmetic outcome; however, some studies also suggest that oncoplastic surgery leads to a worse cosmetic outcome ${ }^{26}$, possibly as a consequence of the resulting larger boost volumes combined with more tissue damage due to extended devascularisation of the intramammary tissue flaps. The most important issues that need further studies are both the influence of extensive oncoplastic surgery and the influence of primary chemotherapy on cosmetic outcome.

\section{Conclusion}

The 4 year results of the YBT show that a photon boost, a high boost dose, poor cosmesis before RT, large boost volume, and adjuvant chemotherapy result in worse cosmetic outcome. These data offer valuable tools to develop strategies aimed at improving cosmetic outcome. 


\section{Acknowledgements}

This publication was supported by a Pink Ribbon grant (2011.WO04.C94). The French part of the trial was funded by the French Ministry of Health PHRC2009 and PHRC2012 grants.

Further, the authors thank J. Cardoso and M. Cardoso for the use of the BCCT.core software program, and B. Hanbeukers for analysing the majority of digital photographs using the BCCT.core. software.

Also, we acknowledge and thank Jerôme Lemonnier, project leader in France, for coordinating the Young Boost Trial in France and the following for their active participation: M. van Hezewijk, Leiden (NL); M.J.C. van der Sangen Eindhoven (NL); M.C. Stenfert Kroese, Deventer (NL); J.J.Jobsen, Enschede (NL); J.M. Immink, Delft (NL); M.E. Mast, Den Haag (NL); F.M. Gescher, Den Haag (NL); N. Bijker, Amsterdam (NL); J.W.M. Mens, Rotterdam (NL); W.G.J.M. Smit, Leeuwarden (NL); D.H.F. Rietveld, Amsterdam (NL); I. Lecouillard, Rennes (Fr); C Breton-Callu, Bordeaux (Fr); H. Marsiglia, Villejuif (Fr); J. Thariat, Nice (Fr); A. Benyoucef, Rouen (Fr); A. Labib, Saint Cloud (Fr); M. Aumont, Saint Herblain (Fr); P. Bontemps, Besancon (Fr); C. Le Foll, Lagny (Fr); Y. Belkacemi, Créteil (Fr); O. Chapet, Lyon (Fr); V. Strnad, Erlangen (De) 


\section{$\underline{\text { Right breast }}$}

16

11

19

15

14

18

\section{Left breast}

26

$22 \quad 21$

$25 \quad 29$

$23 \quad 24$

28

Supplementary figure. Tumour location.

The number represents the dominant location of the lesion. We lumped several regions together to create the different tumour locations: central under, lateral en medial upper.

Central under: 13, 14, 15 and 18 (right breast) and 23, 24, 25 and 28 (left breast).

Lateral: 11 and 19 (right breast) and 21 and 29 (left breast).

Medial-up: 12, 16 and 17 (right breast) and 22, 26 and 27 (left breast). 


\begin{tabular}{|c|c|c|c|c|c|c|}
\hline $\mathrm{N}$ & $\begin{array}{l}\text { Major protocol } \\
\text { violation }\end{array}$ & $\mathrm{N}$ & $\begin{array}{l}\text { Minor protocol } \\
\text { violation }\end{array}$ & $\mathrm{N}$ & $\begin{array}{l}\text { Unknown major / } \\
\text { minor protocol } \\
\text { violation }\end{array}$ & Total \\
\hline 4 & $\begin{array}{l}\text { higher tumour stage } \\
\text { than allowed }\end{array}$ & 12 & $\begin{array}{l}\text { informed consent was } \\
\text { received too late }\end{array}$ & 4 & $\begin{array}{l}\text { released by the } \\
\text { investigator without } \\
\text { giving a reason }\end{array}$ & \\
\hline 2 & $\begin{array}{l}\text { residual } \\
\text { microcalcifications on } \\
\text { the post-operative } \\
\text { mammography }\end{array}$ & 6 & $\begin{array}{l}\text { delay in start of } \\
\text { radiation therapy } \\
\text { after surgery }\end{array}$ & 8 & $\begin{array}{l}\text { no reason was given of } \\
\text { why inclusion criteria } \\
\text { were not met }\end{array}$ & \\
\hline 3 & mastectomy & 1 & 51 years old & & & \\
\hline 2 & different pathology & & & & & \\
\hline 1 & $\begin{array}{l}\text { withdrawn on patients' } \\
\text { consent }\end{array}$ & & & & & \\
\hline 1 & multifocal tumour & & & & & \\
\hline 1 & no baseline photograph & & & & & \\
\hline 1 & $\begin{array}{l}\text { neoadjuvant } \\
\text { chemotherapy }\end{array}$ & & & & & \\
\hline 15 & & 19 & & 12 & & 46 \\
\hline
\end{tabular}

Supplementary file table A. Protocol violations. The investigators were asked whether or not inclusion criteria were met. Not always a reason was given why inclusion criteria were not met (last column).

Only patients with available digital photographs were included in the analysis. 


\section{References:}

1. Clarke M, Collins R, Darby S, et al. Effects of radiotherapy and of differences in the extent of surgery for early breast cancer on local recurrence and 15-year survival: an overview of the randomised trials. Lancet. 2005;366(9503):2087-2106. doi:10.1016/S0140-6736(05)67887-7.

2. Poortmans PM, Collette L, Bartelink $\mathrm{H}$, et al. The addition of a boost dose on the primary tumour bed after lumpectomy in breast conserving treatment for breast cancer. A summary of the results of EORTC 22881-10882 "boost versus no boost" trial. Cancer Radiother. 2008;12(6-7):565-570. doi:10.1016/j.canrad.2008.07.014.

3. Bartelink $\mathrm{H}$, Horiot J-C, Poortmans PM, et al. Impact of a higher radiation dose on local control and survival in breast-conserving therapy of early breast cancer: 10-year results of the randomized boost versus no boost EORTC 22881-10882 trial. J Clin Oncol. 2007;25(22):32593265. doi:10.1200/JCO.2007.11.4991.

4. Barnett GC, Wilkinson JS, Moody a M, et al. The Cambridge Breast Intensity-modulated Radiotherapy Trial: patient- and treatment-related factors that influence late toxicity. Clin Oncol (R Coll Radiol). 2011;23(10):662-673. doi:10.1016/j.clon.2011.04.011.

5. Peterson D, Truong PT, Parpia S, et al. Predictors of Adverse Cosmetic Outcome in the RAPID Trial: An Exploratory Analysis. Int J Radiat Oncol. 2015;91(5):968-976. doi:10.1016/j.ijrobp.2014.12.040.

6. Vrieling C, Collette L, Fourquet A, et al. The in - uence of patient, tumor and treatment factors on the cosmetic results after breast-conserving therapy in the EORTC ' boost vs . no boost âf $€^{\mathrm{TM}}$ trial. 2000;55.

7. Immink JM, Putter $\mathrm{H}$, Bartelink $\mathrm{H}$, et al. Long-term cosmetic changes after breast-conserving treatment of patients with stage I-II breast cancer and included in the EORTC "boost versus no boost" trial. Ann Oncol. 2012;23(10):2591-2598. doi:10.1093/annonc/mds066.

8. Mukesh MB, Harris E, Collette $\mathrm{S}$, et al. Normal tissue complication probability (NTCP) parameters for breast fibrosis: pooled results from two randomised trials. Radiother Oncol. 2013;108(2):293-298. doi:10.1016/j.radonc.2013.07.006.

9. Collette $\mathrm{S}$, Collette L, Budiharto $\mathrm{T}$, et al. Predictors of the risk of fibrosis at 10 years after breast conserving therapy for early breast cancer: a study based on the EORTC Trial 2288110882 "boost versus no boost". Eur J Cancer. 2008;44(17):2587-2599. doi:10.1016/j.ejca.2008.07.032.

10. Vrieling $C$, Collette $L$, Fourquet $A$, et al. The Influence of the Boost in Breast-conserving Therapy on Cosmetic Outcome in the EORTC "Boost versus no Boost " Trial. Int J Radiat Oncol. 1999;45(3):677-685.

11. Hammer C, Maduro JH, Bantema-Joppe EJ, et al. Radiation-induced fibrosis in the boost area after three-dimensional conformal radiotherapy with a simultaneous integrated boost technique for early-stage breast cancer: A multivariable prediction model. Radiother Oncol. 2017;122(1):45-49. doi:10.1016/j.radonc.2016.10.006.

12. Brouwers PJAM, van Werkhoven E, Bartelink $\mathrm{H}$, et al. Factors associated with patientreported cosmetic outcome in the Young Boost Breast Trial. Radiother Oncol. 2016;120(1):107-113. doi:10.1016/j.radonc.2016.04.017.

13. Sobin LH, Gospodarowicz MK WC. TNM Classification of Malignant Tumors.; 2002. http://eu.wiley.com/WileyCDA/WileyTitle/productCd-1444332414.html.

14. Scott NW, McPherson GC, Ramsay CR, Campbell MK. The method of minimization for allocation to clinical trials: A review. Control Clin Trials. 2002;23(6):662-674. 
doi:10.1016/S0197-2456(02)00242-8.

15. Cardoso MJ, Cardoso J, Amaral N, et al. Turning subjective into objective: the BCCT.core software for evaluation of cosmetic results in breast cancer conservative treatment. Breast. 2007;16(5):456-461. doi:10.1016/j.breast.2007.05.002.

16. Cardoso JS, Cardoso MJ. Towards an intelligent medical system for the aesthetic evaluation of breast cancer conservative treatment. Artif Intell Med. 2007;40(2):115-126. doi:10.1016/j.artmed.2007.02.007.

17. Harris JR, Levene MB, Svensson G, Hellman S. Analysis of cosmetic results following primary radiation therapy for stages I and II carcinoma of the breast. Int J Radiat Oncol. 1979;5(2):257-261. doi:10.1016/0360-3016(79)90729-6.

18. Sneeuw KC, Aaronson NK, Yarnold JR, et al. Cosmetic and functional outcomes of breast conserving treatment for early stage breast cancer. 1. Comparison of patients' ratings, observers' ratings, and objective assessments. Radiother Oncol. 1992;25(3):153-159. http://www.ncbi.nlm.nih.gov/pubmed/1470691.

19. Al Uwini S, Antonini N, Poortmans PM, et al. The influence of the use of CT-planning on the irradiated boost volume in breast conserving treatment. Radiother Oncol. 2009;93(1):87-93. doi:10.1016/j.radonc.2009.05.002.

20. Mukesh MB, Barnett GC, Wilkinson JS, et al. Randomized controlled trial of intensitymodulated radiotherapy for early breast cancer: 5-year results confirm superior overall cosmesis. J Clin Oncol. 2013;31(36):4488-4495. doi:10.1200/JCO.2013.49.7842.

21. Lazzari G, Terlizzi A, Della Vittoria Scarpati G, et al. Predictive parameters in hypofractionated whole-breast 3D conformal radiotherapy according to the Ontario Canadian trial. Onco Targets Ther. 2017;10:1835-1842. doi:10.2147/OTT.S127833.

22. Veldeman L, Schiettecatte K, De Sutter C, et al. The 2-year cosmetic outcome of a randomized trial comparing prone and supine whole-breast irradiation in large-breasted women. Int J Radiat Oncol Biol Phys. 2016;95(4):1210-1217. doi:10.1016/j.ijrobp.2016.03.003.

23. Haviland JS, Owen JR, Dewar J a., et al. The UK Standardisation of Breast Radiotherapy (START) trials of radiotherapy hypofractionation for treatment of early breast cancer: 10-year follow-up results of two randomised controlled trials. Lancet Oncol. 2013;14(11):1086-1094. doi:10.1016/S1470-2045(13)70386-3.

24. Whelan TJ, Pignol J-P, Levine MN, et al. Long-term results of hypofractionated radiation therapy for breast cancer. N Engl J Med. 2010;362(6):513-520. doi:10.1056/NEJMoa0906260.

25. Bantema-Joppe EJ, Schilstra C, de Bock GH, et al. Simultaneous integrated boost irradiation after breast-conserving surgery: physician-rated toxicity and cosmetic outcome at 30 months' follow-up. Int J Radiat Oncol Biol Phys. 2012;83(4):e471-7. doi:10.1016/j.ijrobp.2012.01.050.

26. Lansu JTP, Essers M, Voogd AC, et al. The influence of simultaneous integrated boost, hypofractionation and oncoplastic surgery on cosmetic outcome and PROMs after breast conserving therapy. Eur J Surg Oncol. 2015;41(10):1411-1416. doi:10.1016/j.ejso.2015.07.011.

27. Keller LMM, Sopka DM, Li T, et al. Five-year results of whole breast intensity modulated radiation therapy for the treatment of early stage breast cancer: The fox chase cancer center experience. Int J Radiat Oncol Biol Phys. 2012;84(4):881-887. doi:10.1016/j.ijrobp.2012.01.069.

28. Franco P, Cante D, Sciacero P, Girelli G, La Porta MR, Ricardi U. Tumor bed boost integration during whole breast radiotherapy: A review of the current evidence. Breast Care.

2015;10(1):44-49. doi:10.1159/000369845. 
29. González Sanchis A, Brualla González L, Fuster Diana C, et al. Tumor bed segmentation: first step for partial breast irradiation. Clin Trans/ Oncol. 2013;15(1):39-45. doi:10.1007/s12094012-0884-1.

30. Furet E, Peurien D, Fournier-Bidoz N, et al. Plastic surgery for breast conservation therapy: how to define the volume of the tumor bed for the boost? Eur J Surg Oncol. 2014;40(7):830834. doi:10.1016/j.ejso.2014.03.009.

31. Boersma L, Janssen T, Elkhuizen PHM, et al. Reducing interobserver variation of boost-CTV delineation in breast conserving radiation therapy using a pre-operative $\mathrm{CT}$ and delineation guidelines. Radiother Oncol. 2012;103(2):178-182. doi:10.1016/j.radonc.2011.12.021.

32. van der Heiden-van der Loo M, Siesling S, Wouters MWJM, van Dalen T, Rutgers EJT, Peeters PHM. The Value of Ipsilateral Breast Tumor Recurrence as a Quality Indicator: Hospital Variation in the Netherlands. Ann Surg Oncol. 2015;22 Suppl 3:522-528. doi:10.1245/s10434015-4626-9.

33. Poortmans PMP, Arenas M, Livi L. Over-irradiation. The Breast. 2017;31:295-302. doi:10.1016/j.breast.2016.07.022.

34. Kirova YM, Castro Pena P, Hijal T, et al. Improving the definition of tumor bed boost with the use of surgical clips and image registration in breast cancer patients. Int J Radiat Oncol Biol Phys. 2010;78(5):1352-1355. doi:10.1016/j.ijrobp.2009.10.049. 


\section{Chapter 4}

Set-up verification and 2-dimensional electronic portal imaging device dosimetry during breath hold compared with free breathing in breast cancer radiation therapy

Patricia J.A.M. Brouwers MD, Tim Lustberg BSc, Jacques H. Borger MD, PhD, Angela A.W. van Baardwijk MD, PhD, Jos J. Jager MD, PhD, Lars H.P. Murrer PhD, Sebastian M.J.J.G. Nijsten PhD, Bart H. Reymen MD, Judith G.M. van Loon MD, PhD, Liesbeth J. Boersma MD, PhD

Practical Radiation Oncology (2015) 5, e135-e141 


\begin{abstract}
Purpose: To compare set-up and 2-dimensional (2D) electronic portal imaging device (EPID) dosimetry data of breast cancer patients treated during voluntary moderately deep inspiration breath hold (vmDIBH) and free breathing (FB).

Methods and materials: Set-up data were analysed for 29 and 51 consecutively treated patients, irradiated during FB and vmDIBH, respectively. Of the $51 \mathrm{vmDIBH}$ patients, the first 25 had undergone an extra trained computed tomography (CT) scan and used an additional "breathing stick" (vmDIBH_trained). The last 26 patients did not use the breathing stick and did not undergo a trained CT (vmDIBH_untrained). The delivered 2D transit dose was measured with EPID in 15 FB and 28 vmDIBH patients and compared with a 2D predicted dose by calculating global gamma values $\gamma$ using $5 \%$ and $5 \mathrm{~mm}$ as dose difference and distance-to-agreement criteria, respectively. Measurements with a percentage of pixels with an absolute gamma value $>1(|\gamma|>1)$ greater than $10 \%$ were classified as deviating.
\end{abstract}

Results: Only small, sub-millimeter differences were seen in the set-up data between the different patient groups. The mean of means, systematic error, and random error ranged from $-0.6 \mathrm{~mm}$ to 3.3 $\mathrm{mm}$. The percentage of pixels with $|\gamma|>1$ for all patients was $9.8 \%$ (2-25.8). No statistically significant differences were observed between the patient groups. In total, $38 \%$ of the gamma images were classified as deviating: $43.6 \%$ in vmDIBH_untrained patients compared with $38.0 \%$ in vmDIBH_trained patients and $33.3 \%$ in FB patients $(P>0.05)$.

Conclusion: Both set-up and 2D EPID dosimetry data indicate that reproducibility of radiation therapy for patients treated during FB and vmDIBH is similar. Small but not significant differences in 2D EPID dosimetry were observed. Further investigation with 3-dimensional EPID dosimetry is recommended to investigate the clinical relevance of deviant gamma images. 


\section{Introduction}

The conventional technique of breast and thoracic wall irradiation is by tangential fields, implicating that the heart and lungs can be partially located within the radiation field. Several reports have shown that heart irradiation may lead to late cardiac toxicity ${ }^{1}$. In addition, several articles report that lung injury occurs from breast irradiation, although the incidence of clinically relevant radiation pneumonitis is fortunately quite low ${ }^{2}$.

In the literature, a significantly increased risk of cardiac death has been observed for patients treated with left-sided breast cancer 20-30 years ago ${ }^{3}$. The incidence of cardiac injury using modern radiation therapy techniques is not completely clear, however. Although Offersen et al $^{4}$ described several uncertainties with respect to parameters related to radiation-induced heart injury, it seems clear that both radiation dose and volume play an important role in the development of both heart and lung toxicity. Consequently, reducing both irradiated volume and dose to the heart and lung is expected to reduce heart and lung toxicity.

Multiple respiratory techniques have been described to spare both heart and lung, taking into account that during deep inspiration the heart moves out of the radiation field and the relative volume of irradiated lung is reduced. This can be achieved using voluntary breath hold techniques ${ }^{5-8}$, an Active Breathing Control $(A B C)$ device $^{9}$ or gating ${ }^{7,10}$. For the latter 2, additional equipment is required, whereas the voluntary method appears to be easy and inexpensive. However, concerning voluntary breath hold, reproducibility is often questioned. Only a limited number of studies ${ }^{5,11-13}$ analysed setup in breath hold, but none of these studies reported actual measured transit dose for verification.

The aim of this article is to investigate whether the reproducibility of voluntary moderately deep inspiration breath hold (vmDIBH) is similar to free breathing (FB) by reporting set-up and 2dimensional (2D) EPID dosimetry data, acquired during the development of the vmDIBH technique in our institute.

\section{Methods and materials}

\section{Patients}

In our institute, vmDIBH was implemented in 2005. In 2008, we started a step-by-step process to simplify the logistics, that is, 2 computed tomography (CT) scans on 1 day, instead of 3 CT scans in 2 days, as described later. Data were obtained in 80 consecutive breast cancer patients, treated in a 


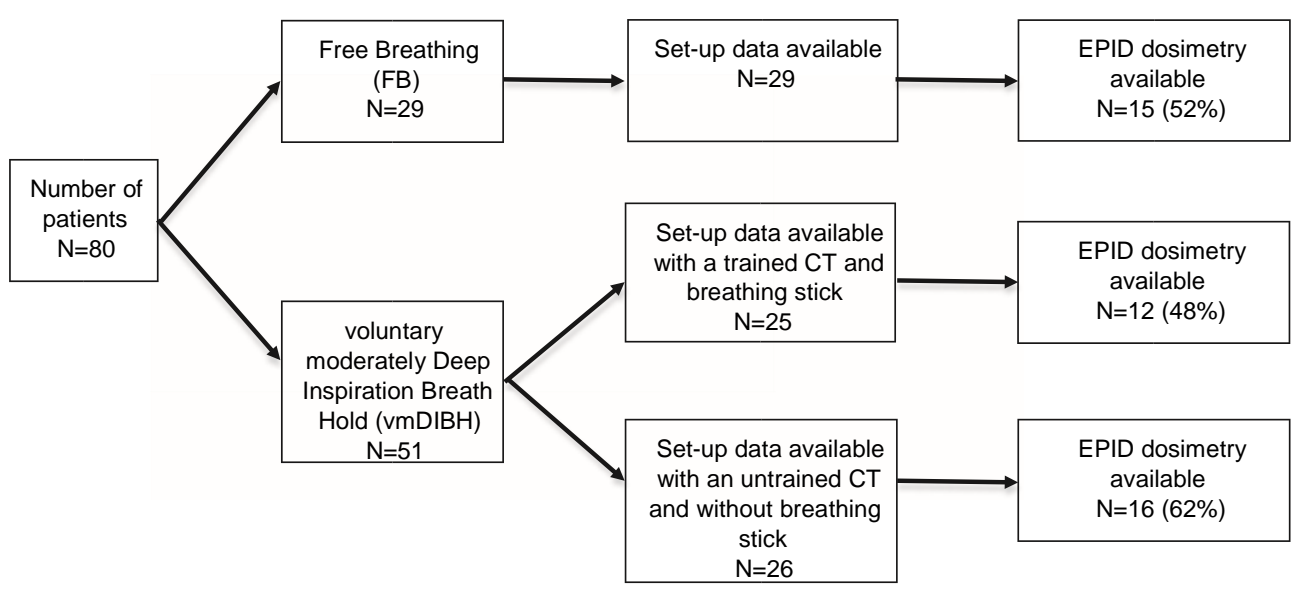

Figure 1 Schematic overview of number of patients and available data.

fixed period between October 2008 and October 2009 (Fig 1). During the period of the simplification process, 3 treatment groups could be distinguished:

1) Control group (ie, $\mathrm{FB}$ patients; $\mathrm{N}=29$ ).

2) vmDIBH patients with $3 \mathrm{CT}$ scans and using an additional aid called the "breathing stick" $(\mathrm{N}=25)$, developed to assist patients to achieve a reproducible breath hold (Fig 2). These patients first underwent 2 planning $\mathrm{CT}$ scans: 1 during $\mathrm{FB}$ and 1 during untrained $\mathrm{vmDIBH}^{9}$. Both scans were compared, and if the maximum heart distance (MHD, Fig 3) was $\geq 1 \mathrm{~cm}$ in the $F B$ scan and $<1 \mathrm{~cm}$ in the vmDIBH, it was decided to treat the patient during breath hold. The patient was then phoned and asked to practice the breath hold at home, using written breath-hold instructions. After practicing breath hold at home, a third, trained vmDIBH CT scan was obtained, which was used for treatment planning.

3) vmDIBH patients with only 2 untrained $C T$ scans and without the breathing stick $(N=26)$. To investigate whether omitting the third CT scan would be safe, we performed an "interim in-silico" comparison in 10 patients of group 2: the digitally reconstructed radiographs (DRRs) for the tangential fields of the untrained vmDIBH CT scan were compared with the DRRs of the trained vmDIBH CT scan. We found a small set-up difference, manageable by our set-up protocol, but no clinically relevant difference was seen in the MHD (mean difference $0.3 \mathrm{~mm} \pm 1.8$ ). Based upon this analysis, we decided to omit the third trained vmDIBH CT scan, and used the untrained vmDIBH CT scan for treatment planning. At the same time, we omitted the breathing stick. 


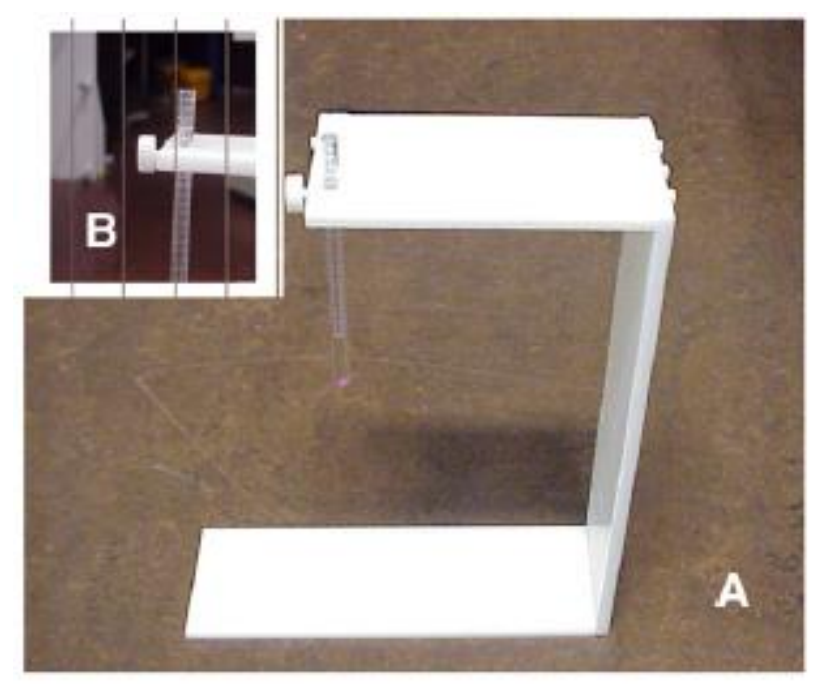

Figure 2 (A) The "breathing stick" that was placed on the skin of the patient outside the radiation fields in the epigastric area during breath hold and (B) an integrated ruler. The contact point of the tip of the ruler was marked by a dot on the skin during the third computed tomography scan in voluntary moderately deep inspiration breath hold (vmDIBH). During treatment, the radiation technician could check visually, and the patient could feel, whether the tip of the stick made contact at the dot on the skin, ensuring a correct breath hold.

\section{Methods}

\section{CT scanning and treatment planning}

Patients were scanned in the supine position with the arms above the head in an arm support (Civco, Posirest-2, USA), and the legs resting on a Kneefix (Civco). All CT scans were obtained with 3-mm slice thickness from the level of the mandible down to the diaphragm (Siemens Somatom Sensation).

Treatment planning was performed using forward intensity modulated radiation therapy planning as described earlier ${ }^{14}$. The target volume consisted of the breast or thoracic wall with or without regional lymph nodes.

\section{Set-up verification}

A shrinking action level protocol was used for set-up verification, with $\alpha=10$ and $n=3^{15}$ for all patients. Four skin markers were placed onto the skin at the medial, lateral, cranial, and caudal edges of the breast or thoracic wall. Both lateral and anteroposterior electronic portal images (EPIs) were matched to the DRRs using both anatomy and skin markers ${ }^{16}$. 
Differences between the EPIs and the DRRs were analysed in 3 directions: left-right, craniocaudal, and anteroposterior. The mean of means $(\mu)$ was determined by calculating the average of the individual systematic set-up errors for all patients. The systematic set-up error for the population $(\Sigma)$ was calculated by taking the standard deviation of the individual systematic set-up errors for all patients. The random set-up error of the population $(\sigma)$ was calculated by taking the average of the individual random set-up errors for all patients ${ }^{17}$.
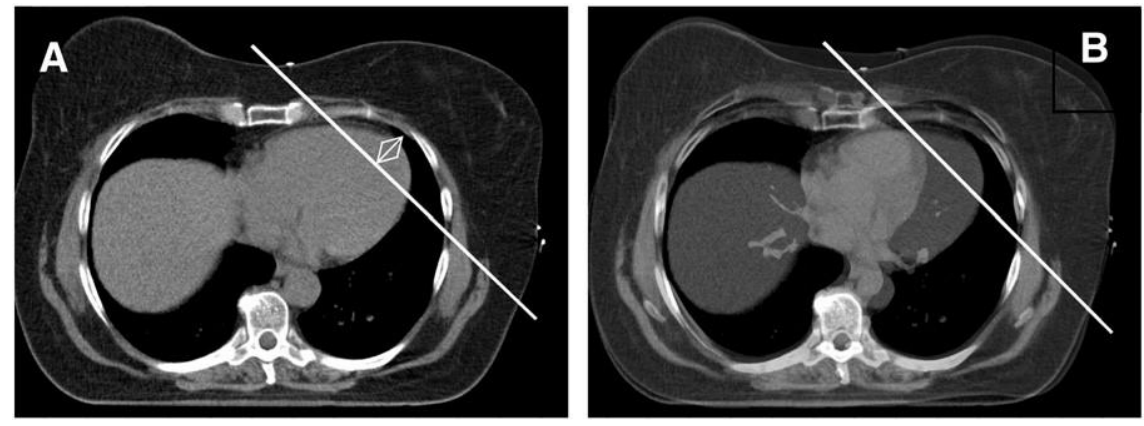

Figure 3. The maximum heart distance is the maximum distance between the heart contour and the posterior field border of a tangential treatment beam. (A) In free breathing, the heart is partially located within the radiation field; (B) in voluntary moderately deep inspiration breath hold (vmDIBH), the heart moves out the radiation field.

\section{Dose verification}

According to the clinical protocol, 2D transit dose distributions were measured during the first 3 fractions, thereafter weekly, using EPIs. OptiVue 500/1000/1000 ST amorphous silicon flat panel portal imagers (Siemens Medical Solutions, Concord, CA), attached to Oncor medical linear accelerators (Siemens Medical Solutions), were used for these measurements. The measured delivered transit dose was compared with a predicted dose by calculating global gamma values using $5 \%$ and $5 \mathrm{~mm}$ as dose difference and distance-to-agreement criteria ${ }^{18}$. The percentage of pixels with an absolute gamma value $>1(|\gamma|>1)$ was determined only for lateromedial and mediolateral beams. Median values of this parameter were compared among the 3 patient groups. Measurements with a percentage of pixels $|\gamma|>1$ greater than $10 \%$ were classified as deviating. Deviant gamma images were inspected visually. Only if 1 part of the image showed clear underdosage and the other part showed clear overdosage, the dose difference was considered to be due to a simple translation (set-up error/organ motion); if the gamma image showed other patterns of over- and/or underdosage, the 
dose difference was considered to be due to rotation, change in breast shape or a combination of both (Fig 4).

Because the treatment fields did not always fit within the field of view of the flat panel portal imagers, EPID dosimetry data could not be evaluated for all patients. In total, 241, 590, and 565 measurements were obtained for $15 \mathrm{FB}, 12 \mathrm{vmDIBH}$ patients with trained $\mathrm{CT}$, and $16 \mathrm{vmDIBH}$ patients with an untrained $\mathrm{CT}$, respectively (Fig $\mathbf{1}$ ).
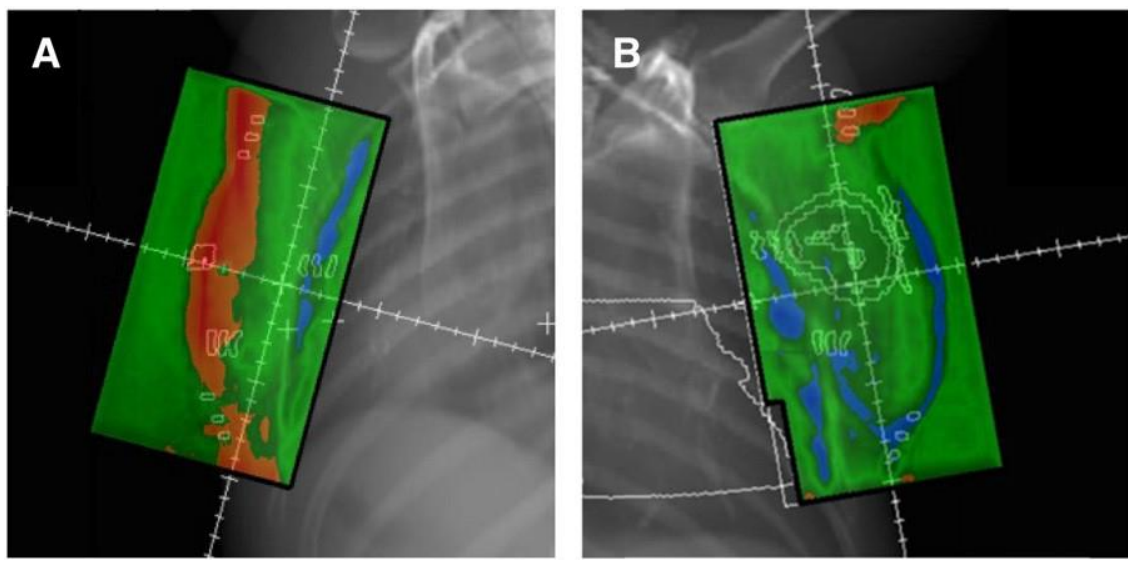

Figure 4. Examples of gamma images of a tangential breast field. Red and blue colors represent regions where the measured dose is higher or lower than planned, respectively, whereas green represents regions where the planned and measured dose are in agreement. (A) A typical simple translation and (B) an example of rotation or changes in breast shape.

\section{Analysis and statistics}

Set-up data were analysed and compared for the 3 treatment groups: $25 \mathrm{vmDIBH}$ patients treated with trained CT (vmDIBH_trained), $26 \mathrm{vmDIBH}$ patients without trained CT (vmDIBH_untrained), and $29 \mathrm{FB}$ patients. Mean of means, random error, and systematic error of the vmDIBH patients were calculated for this purpose. In addition, the number of measurements and applied set-up corrections was counted for the 3 treatment groups. The percentage of deviant measurements and of dose differences interpreted as from a translation were compared between the patient groups. We were particularly interested in translations, because we assumed that a change in breath hold would likely show up as translations. In all analyses, the Kruskal-Wallis test was used with $p<0.05$ as the level of significance. In case of a significant difference, a Mann-Whitney test was used for detailed analysis. Median results are noted with range in parentheses. 


\section{Results}

Patient characteristics are listed in Table 1. All vmDIBH patients had left-sided breast cancer, with an assumed benefit from vmDIBH, based upon a reduction of the maximum heart distance (Fig 3). FB patients had right or left-sided breast cancer, assuming that laterality does not influence set-up accuracy. In 1 patient, vmDIBH was not feasible because of shortness of breath; in all other patients, vmDIBH had no added value.

\begin{tabular}{lccc}
\hline \hline & Median age & \multicolumn{2}{c}{ Type of surgery } \\
\cline { 3 - 4 } & and range & Mastectomy & $\begin{array}{c}\text { Breast conserving } \\
\text { surgery }\end{array}$ \\
\hline Free breathing & $64(42-83)$ & 9 & 20 \\
vmDIBH_trained & $53(41-68)$ & 4 & 21 \\
vmDIBH_untrained & $51(37-70)$ & 2 & 24 \\
\hline \hline
\end{tabular}

Table 1. Patient characteristics

$\mathrm{FB}=$ free breathing; $\mathrm{vmDIBH}=$ voluntary moderately deep inspiration breath hold.

Using the Kruskal-Wallis test, age of FB patients is significantly higher than both vmDIBH patient groups $(p<0.001)$. Although a clear trend is seen, type of surgery is not significantly different (chisquared test: $p>0.05)$.

\section{Analysis of set-up data}

The systematic error in all patients varied between 1.2 and $2.0 \mathrm{~mm}$; the random error between 2.2 and $3.3 \mathrm{~mm}$. Mean of means varied between -0.6 and $0.9 \mathrm{~mm}$ (Table 2). The random error showed a significant difference in craniocaudal direction for FB compared with vmDIBH_trained, whereas the mean of means showed a significant difference in the anteroposterior direction for FB compared with vmDIBH_trained and vmDIBH_untrained. Although the number of measurements for vmDIBH_untrained was larger than for FB patients $(p=0.03)$, the number of set-up corrections was similar $(p<0.2)$ (Table 3). 


\begin{tabular}{|c|c|c|c|c|c|c|c|c|c|}
\hline & \multicolumn{3}{|c|}{ Mean of means $\mu(\mathrm{mm})$} & \multicolumn{3}{|c|}{ Systematic error $\Sigma(\mathrm{mm})$} & \multicolumn{3}{|c|}{ Random error $\sigma(\mathrm{mm})$} \\
\hline & $\mathrm{LR}$ & CC & $\mathrm{AP}$ & LR & $\mathrm{CC}$ & $A P$ & LR & $\mathrm{CC}$ & AP \\
\hline \multicolumn{10}{|c|}{ All patients } \\
\hline$(N=80)$ & 0.4 & 0.7 & -0.0 & 1.7 & 1.6 & 2.0 & 2.8 & 2.7 & 3.2 \\
\hline \multicolumn{10}{|l|}{ FB } \\
\hline$(N=29)$ & 0.2 & 0.7 & 0.7 & 2.0 & 1.6 & 2.0 & 2.9 & 2.2 & 3.1 \\
\hline \multicolumn{10}{|c|}{ vmDIBH_trained } \\
\hline$(N=25)$ & 0.4 & 0.6 & -0.3 & 1.2 & 1.9 & 2.0 & 2.8 & 3.0 & 3.1 \\
\hline \multicolumn{10}{|c|}{ vmDIBH_untrained } \\
\hline$(N=26)$ & 0.6 & 0.9 & -0.6 & 1.7 & 1.4 & 1.9 & 2.6 & 3.0 & 3.3 \\
\hline$p$ value & 0.7 & 0.9 & 0.04 & & & & 0.7 & 0.01 & 0.8 \\
\hline
\end{tabular}

Table 2. Set-up data of all patients and subdivided by treatment group

AP: anteroposterior; CC: craniocaudal; FB: free breathing; LR: left-right; vmDIBH: voluntary moderately deep inspiration breath hold.

Using a Kruskal-Wallis test, significant differences were found in mean of means (AP) and random error (CC) among the 3 groups. Detailed analysis using a Mann-Whitney test showed a significant difference in mean of means in AP direction between FB and vmDIBH_untrained $(p=0.02)$ and in random error in CC direction between FB and vmDIBH_trained and vmDIBH_untrained $(p<0.02)$.

\section{Analysis of 2D EPID dosimetry data}

The median percentage of pixels with $|\gamma|>1$ for all patients was $9.8 \%(2-25.8 \%)$ (Table 4). The percentage of deviating images was somewhat higher in vmDIBH patients (vmDIBH_trained $(38 \%)$ and vmDIBH_untrained (43.6\%)) than in FB (33.3\%), but the difference was not statistically significant. Visual inspection of deviant gamma images showed no significant difference in the percentage of deviating gamma images attributed to translation in vmDIBH_trained, vmDIBH_untrained, and FB patients (14.9\% [0-66.6\%], 12.7\% [0-83.3\%], and 0 [0-100\%], respectively). No differences were seen between mediolateral and lateromedial beams (all $p>0.3$ ). 


\begin{tabular}{lcc}
\hline \hline & $\begin{array}{c}\text { Median no. of measurements } \\
\text { (range) }\end{array}$ & $\begin{array}{c}\text { Median no. of corrections } \\
\text { (range) }\end{array}$ \\
\hline \hline Free breathing & $8(4-12)$ & $1(0-4)$ \\
vmDIBH_trained & $9(4-18)$ & $1(0-7)$ \\
vmDIBH_untrained & $10(5-16)$ & $1(0-4)$ \\
\hline \hline
\end{tabular}

Table 3. Median numbers of set-up measurements and median number of corrections per patient for the 3 patient groups $F B=$ free breathing; $v m D I B H=$ voluntary moderately deep inspiration breath hold.

Comparing the 3 groups with the Kruskal-Wallis test, vmDIBH_untrained patients had a larger number of set-up measurements than FB patients $(p=0.03)$. However, the number of corrections per patient was similar for the 3 patient groups $(p>0.2)$.

\section{Discussion}

To our knowledge, this is the first article reporting on both set-up and in vivo dosimetric data obtained during vmDIBH. Although the dosimetry data showed remarkably large deviations, differences in setup errors between FB and vmDIBH were extremely small (sub-millimeter) and comparable with data reported earlier in FB patients ${ }^{19,20}$. Therefore, we consider VmDIBH to be as reproducible as standard FB techniques. Furthermore, we showed that by careful step-by-step introduction of vmDIBH, an easy, widely applicable procedure can be obtained.

\section{Comparison with literature}

Set-up data specific for vmDIBH are sparsely available in literature. Lu et al performed repeated CT scans and showed that all patients $(N=15)$ except 1 reasonably reproduced their position between different breath-holding cycles ${ }^{7}$. The Netherlands Cancer Institute described set-up data in patients during radiation therapy in DIBH. Set-up deviations (systematic error) in the order of 1.4-2.9 $\mathrm{mm}^{13}, \leq$ $1.7 \mathrm{~mm} 11$, and $\leq 1.4 \mathrm{~mm}$ were reported 12 , which are comparable with the $1.2-2 \mathrm{~mm}$ found in the current study. 


\begin{tabular}{lccc}
\hline \hline & $\begin{array}{c}\text { Median \% of pixels with } \\
|\mathrm{y}|>1 \text { per patient } \\
\text { and range }\end{array}$ & $\begin{array}{c}\text { Median \% of } \\
\text { deviating } \\
\text { measurements } \\
\text { and range }\end{array}$ & $\begin{array}{c}\text { Median \% of } \\
\text { deviating measurements } \\
\text { resulting from a translational } \\
\text { set-up error and range }\end{array}$ \\
\hline $\begin{array}{c}\text { All patients together } \\
\mathrm{N}=1396\end{array}$ & $9.8(2.0-25.8)$ & $38.0(4.2-81.3)$ & $13.7(0-100)$ \\
$\begin{array}{c}\text { Free breathing } \\
\mathrm{N}=241\end{array}$ & $8.2(2.0-25.0)$ & $33.3(7.1-64.3)$ & $0.0(0-100)$ \\
vmDIBH_trained \\
$\mathrm{N}=590$
\end{tabular}

Table 4. Analysis of 2D EPID dosimetry data

No significant differences were found ( $p>0.3$, Kruskal-Wallis test).

Theoretically, one would assume that $A B C$ (i.e. breath hold with an additive device) results in better set-up reproducibility. This assumption, however, is not confirmed in the literature ${ }^{9,21,22}$. Recently, the results of the UK HeartSpare Study were published and suggest that $A B C$ and $v m D I B H$ are comparable both in terms of positional reproducibility and normal tissue sparing. In addition, patients experience vmDIBH more comfortably than with an $\mathrm{ABC}^{23}$.

Although our set-up errors were reasonably small and comparable to literature, the measured dose showed remarkably large deviations (i.e. $>10 \%$ pixels with $|\gamma|>1$ ), both for vmDIBH and for FB patients. The clinical relevance of these deviations in 2D dosimetry is still unclear. To our knowledge, only Fidanzio et $\mathrm{al}^{24}$ published results of breast in vivo dosimetry using EPID, but they did not take into account the entire tangential field. They determined the ratio between reconstructed and planned dose at breast midpoint, thus verifying a point dose in the patient and not a $2 \mathrm{D}$ transit dose distribution at the EPID plane. When patient set-up variations were not taken into account, these ratios were within $5 \%$ in $72 \%$ of the checks. Because no comparable dosimetry data are available in the literature and because our set-up data are comparable to those reported in literature, we assume that these dosimetry results would be found in other institutes as well, if measured. This assumption is supported by the article by Topolnjak et $\mathrm{al}^{25}$, who showed that set-up verification easily lead to large differences between predicted and measured transit dose. The latter could also be an explanation for the, although not statistically significant, differences in percentage of deviant dose measurements between FB and vmDIBH patients. 


\section{Limitations}

There are some limitations of the study inherent to its design. First, the number of transit dose measurements was limited because radiation fields used for breast cancer are often larger than the EPID's field of view. The limited size of the flat panel portal imagers is an ongoing problem when using large treatment volumes. Because of this limited amount of EPID dosimetry data, the study might have been underpowered to detect a significant difference among the 3 groups. Second, we verified 2D measured transit dose distributions and not the 3-dimensional (3D) delivered dose inside a patient. Gamma criteria were deliberately chosen to be larger $(5 \%$ and $5 \mathrm{~mm}$; in accordance with protocol at that time) than usually applied in other publications; in the literature, gamma criteria of $3 \%$ and $3 \mathrm{~mm}$ are often used, but usually for pretreatment verification purposes and for verification of the 3D dose inside the patient. Because of changes in breast anatomy and set-up errors, and their large impact on the measured transit dose, the broader gamma criteria were chosen to get a better threshold to decide whether the expected 3D dose differences would be clinically significant and to balance clinical relevance and workload. Although for verification of the 3D delivered dose, 3D EPID dosimetry is preferred. Our institute ${ }^{26}$ showed previously that 2D EPID dosimetry can be used to predict changes in dose-volume histogram parameters, indicating that there is a relation between our 2D data and the $3 \mathrm{D}$ delivered dose, at least for this patient group using tangential breast fields for radiation therapy treatment.

\section{Conclusion}

Both set-up and 2D EPID dosimetry data indicate that reproducibility of radiation therapy for patients treated during FB and $\mathrm{VmDIBH}$ is similar. The observed differences in 2D EPID dosimetry were not statistically significant between vmDIBH and FB techniques. However, further investigation with 3D EPID dosimetry is recommended to investigate the clinical relevance of deviant gamma images. We are currently investigating how EPID dosimetry can be used to develop decision rules for adaptive radiation therapy. 


\section{Acknowledgment}

We thank R. Houben for statistical advice. 


\section{References}

1. Darby SC, Ewertz M, McGale $P$, et al. Risk of ischemic heart disease in women after radiotherapy for breast cancer. N Engl J Med. 2013;368:987-998.

2. Kubo A, Osaki K, Kawanaka T, Furutani S, Ikushima H, Nishitani H. Risk factors for radiation pneumonitis caused by whole breast irradiation following breast-conserving surgery. J Med Invest. 2009;56:99-110.

3. Ewertz $M$, Jensen $A B$. Late effects of breast cancer treatment and potentials for rehabilitation. Acta Oncol. 2011;50:187-193.

4. Offersen B, Højris I, Overgaard M. Radiation-induced heart morbidity after adjuvant radiotherapy of early breast cancer - Is it still an issue? Radiother Oncol. 2011;100:157-159.

5. Lu HM, Cash E, Chen MH, et al. Reduction of cardiac volume in left-breast treatment fields by respiratory maneuvers: A CT study. Int J Radiat Oncol Biol Phys. 2000;47:895-904.

6. Chen MH, Chuang ML, Bornstein BA, Gelman R, Harris JR, Manning WJ. Impact of respiratory maneuvers on cardiac volume within left-breast radiation portals. Circulation. 1997;96:32693272.

7. Korreman SS, Pedersen AN, Aarup LR, Nøttrup TJ, Specht L, Nyström H. Reduction of cardiac and pulmonary complication probabilities after breathing adapted radiotherapy for breast cancer. Int J Radiat Oncol Biol Phys. 2006;65:1375-1380.

8. Pedersen AN, Korreman S, Nyström H, Specht L. Breathing adapted radiotherapy of breast cancer: Reduction of cardiac and pulmonary doses using voluntary inspiration breath-hold. Radiother Oncol. 2004;72:53-60.

9. Remouchamps VM, Letts N, Vicini FA, et al. Initial clinical experience with moderate deepinspiration breath hold using an active breathing control device in the treatment of patients with left-sided breast cancer using external beam radiation therapy. Int J Radiat Oncol. 2003;56:704715.

10. Korreman SS, Pedersen AN, Nøttrup TJ, Specht L, Nyström H. Breathing adapted radiotherapy for breast cancer: Comparison of free breathing gating with the breath-hold technique. Radiother Oncol. 2005;76:311-318.

11. Alderliesten T, Sonke J-J, Betgen A, Honnef J, van Vliet-Vroegindeweij C, Remeijer P. Accuracy evaluation of a 3-dimensional surface imaging system for guidance in deep inspiration breath-hold radiation therapy. Int J Radiat Oncol Biol Phys. 2013;85:536-542.

12. Betgen A, Alderliesten T, Sonke J-J, van Vliet-Vroegindeweij C, Bartelink H, Remeijer P. Assessment of set-up variability during deep inspiration breath hold radiotherapy for breast cancer patients by 3D-surface imaging. Radiother Oncol. 2013;106:225-230.

13. Borst GR, Sonke J-J, den Hollander S, et al. Clinical results of image-guided deep inspiration breath hold breast irradiation. Int J Radiat Oncol Biol Phys. 2010;78:1345-1351.

14. Peulen $\mathrm{H}$, Hanbeukers B, Boersma L, et al. Forward intensity-modulated radiotherapy planning in breast cancer to improve dose homogeneity: Feasibility of class solutions. Int J Radiat Oncol Biol Phys. 2012;82: 394-400.

15. Bel A, van Herk M, Bartelink $H$, Lebesque JV. A verification procedure to improve patient set-up accuracy using portal images. Radiother Oncol. 1993;29:253-260. 
16. Van Der Salm A, Strijbos J, Dijcks C, Murrer L, Borger J, Boersma L. Use of skin markers and electronic portal imaging to improve verification of tangential breast irradiation. Radiother Oncol. 2009;90:106-109.

17. Van Herk M, Remeijer P, Rasch C, Lebesque JV. The probability of correct target dosage: Dosepopulation histograms for deriving treatment margins in radiotherapy. Int J Radiat Oncol Biol Phys. 2000;47:1121-1135.

18. Nijsten SMJJG, van Elmpt WJC, Jacobs M, et al. A global calibration model for a-Si EPIDs used for transit dosimetry. Med Phys. 2007;34:3872.

19. Kukołowicz PF, Debrowski A, Gut P, Chmielewski L, Wieczorek A, Kedzierawski P. Evaluation of setup deviations during the irradiation of patients suffering from breast cancer treated with two different techniques. Radiother Oncol. 2005;75:22-27.

20. Yang DS, Yoon WS, Chung SY, et al. Set-up uncertainty during breast radiotherapy. Image-guided radiotherapy for patients with initial extensive variation. Strahlenther Onkol. 2013;189:315-320.

21. Remouchamps VM, Letts N, Yan D, et al. Three-dimensional evaluation of intra- and interfraction immobilization of lung and chest wall using active breathing control: A reproducibility study with breast cancer patients. Int J Radiat Oncol. 2003;57: 968-978.

22. Moran JM, Balter JM, Ben-David MA, Marsh RB, Van Herk M, Pierce L. Short-term displacement and reproducibility of the breast and nodal targets under active breathing control. Int J Radiat Oncol Biol Phys. 2007;68:541-546.

23. Bartlett FR, Colgan RM, Carr K, et al. The UK HeartSpare Study: Randomised evaluation of voluntary deep-inspiratory breath-hold in women undergoing breast radiotherapy. Radiother Oncol. 2013;108: 242-247.

24. Fidanzio A, Greco F, Mameli A, et al. Breast in vivo dosimetry by EPID. J Appl Clin Med Phys. 2010;2:3275.

25. Topolnjak R, Sonke J-J, Nijkamp J, et al. Breast patient setup error assessment: Comparison of electronic portal image devices and cone-beam computed tomography matching results. Int J Radiat Oncol Biol Phys. 2010;78:1235-1243.

26. Nijsten SMJJG, van Elmpt WJC, Mijnheer BJ, et al. Prediction of DVH parameter changes due to setup errors for breast cancer treatment based on 2D portal dosimetry. Med Phys. 2009;36:8394. 


\section{Chapter 5}

Are PROMs sufficient to record late outcome of breast cancer patients treated with radiotherapy? A comparison between patient and clinician reported outcome through an outpatient clinic after 10 years of follow up.

P.J.A.M. Brouwers, J. van Loon, R.M.A. Houben, J. Paulissen, S.M.E. Engelen, M. Heuts, M. de Boer, K. Verhoeven, D. De Ruysscher, L.J. Boersma.

Brouwers et al, Radiother Oncol 2018: 126(1):163-169. 


\section{Abstract}

Aim: To investigate whether breast cancer patients' visits to an outpatient clinic for late outcome (OCLO) can be replaced by patient reported outcome measures (PROMs), by comparing late toxicity scored at the OCLO with PROMs.

Methods: All breast cancer patients treated in our institute with adjuvant radiotherapy 10-11 years ago were invited to visit the OCLO, and for filling out PROM-questionnaires. Concordance rate between PROMs and OCLO-reported outcome and the percentage of patients with $\geq 2$ degrees difference in toxicity level between patient and clinician was assessed.

Results: 686 of 1029 patients were still alive. 249 patients visited the OCLO, and 341 patients returned a questionnaire. At a group level, patients reported higher toxicity rates than clinicians. The mean concordance for individual patients was $58 \%$ between patient and clinician reported outcome. In $2.8 \%$, the clinician reported $\geq 2$ degrees higher toxicity than the patients did, whereas in $6.8 \%$ patients reported $\geq 2$ degrees higher toxicity.

Conclusion: PROMs do not underestimate late side-effects at a group level. In spite of the low concordance rate, PROMS can be used to identify patients who experience a heavy burden of sideeffects, requiring specific attention. Therefore, patients can be spared a visit to the OCLO. 


\section{Introduction}

The oncological outcome of breast cancer patients has improved substantially, resulting in a growing number of long-term survivors ${ }^{1}$. Consequently, the late side effects of treatment and their impact on quality of life (QoL) are increasingly important ${ }^{2}$. There are several reasons to detect and record these late side-effects:

1) to adequately treat the side-effects and assist patients in coping with them

2) to monitor quality of care and to evaluate the effect of changes in treatment protocols over time

3) to incorporate information on outcome in the process of shared decision making ${ }^{3}$.

The usual way to collect outcome data is through follow-up in outpatient clinics, but due to the improved survival these outpatient clinics are expanding rapidly. Therefore, more cost-effective ways of follow-up have been investigated, showing that follow-up can safely and satisfyingly be performed by general practitioners ${ }^{4}$ or nurses, or even by phone ${ }^{5,6}$. In the Netherlands, in patients older than 60 years, follow-up from 5 years after treatment (i.e. 2-yearly mammography) is largely performed by the general practitioner or via the national screening program in case of mastectomy, according to current national guidelines. Consequently, it is extremely difficult for hospitals to obtain long-term outcome data. Since structural outcome registration is an important prerequisite for improving quality of care, it would be interesting to know whether questionnaires concerning Patient Reported Outcome Measures (PROMs) to score late toxicity can be used instead of a visit to an outpatient clinic. Although both the Cambridge Intensity-modulated Radiotherapy (IMRT) Trial ${ }^{7}$ as well as the START trials $^{8}$ found a low concordance level between late toxicity evaluated by PROMS compared to doctor reported toxicity, in the START trials PROMs were found to be sensitive enough to discriminate differences in late toxicity between fractionation schedules at 5 years. Data on PROMs more than 5 years after treatment are still lacking.

Therefore, we started an outpatient clinic for late outcome (OCLO) at our institute for patients who had received adjuvant radiotherapy for breast cancer $>10$ years ago to evaluate late side effects. The aim of the current paper is to investigate whether breast cancer patients' visits to an outpatient clinic for late outcome (OCLO) can be replaced by PROMs, by comparing the concordance between late toxicity scored at the OCLO with PROMs. For this purpose, we addressed the following questions:

1) Can PROMs be used to monitor quality of care, or to evaluate a change in treatment? For this, concordance between toxicity reported by PROMs and by the clinician on a group level should be determined.

2) Can PROMs be used to identify patients that need special attention for side-effects, i.e. what is the concordance at the individual level between toxicity and outcome registered using PROMs compared to registered by clinicians? 
3) How often do we severely underestimate toxicity by using only PROMs?

4) Can PROMs be used to register oncological outcome, i.e. what is on average the concordance of patient reported and real oncological outcome?

\section{Methods}

Patients and inclusion procedures

The study population consisted of breast cancer patients treated with a curative intent including radiotherapy at least 10 years ago, i.e. between 2002 and 2005. Patients treated for recurrent breast cancer were excluded. Eligible patients were extracted from the digital hospital information system. Survival status was assessed using the population register. Patients alive and whose addresses could be retrieved were asked to visit the OCLO and to fill in PROM-questionnaires. They could respond with an acceptance to visit the OCLO with or without PROM-questionnaires, or a rejection, with or without questionnaires.

Data regarding tumor and treatment characteristics were retrieved from patient files.

Patients who visited the OCLO, were seen by a resident in radiation oncology (PB) or a trial physician assistant (JP), specifically trained for this purpose. The study protocol was approved by the medical ethics committee of the Maastricht University Medical Centre (MUMC+) and registered at ClinicalTrials.gov (NCT01978756).

\section{Outcome measures}

Toxicity

Toxicity was scored both at the OCLO and by using PROM-questionnaires. For late toxicity we focused on cosmetic outcome, fibrosis, shoulder function, lymphedema, neuropathy, fatigue and pain.

At the OCLO, cosmetic outcome was scored on a four-point scale ${ }^{9}$ by the clinician. Physical examination was performed to evaluate fibrosis of the breast using a 4-point scale according to the common toxicity criteria version 4.0 (CTCAE v 4.0). Assessment of lymphedema and shoulder mobility was performed according to the method applied in the AMAROS trial ${ }^{10}$ : lymphedema assessment included recording any sign of lymphedema, and measuring arm circumference of the upper and lower arm ( $15 \mathrm{~cm}$ above and below the medial epicondyle, respectively). Regarding shoulder mobility, the range of motion in both arms in degrees was measured and compared in six excursions: abduction, adduction, anteversion, retroversion, exorotation and endorotation.

To assess late toxicity in the PROM-questionnaires, we used the validated EORTC- QLQ_C30 questionnaire for overall quality of life ${ }^{11}$ and the breast cancer specific BR-23 ${ }^{12}$. For the current paper, we only analyzed question 18 of the EORTC- QLQ_C30 questionnaire concerning fatigue, and 
questions 48,49 and 50 of the BR-23 concerning lymphedema, shoulder function and pain. For cosmetic outcome, the validated questionnaire of Sneeuw et al was used ${ }^{13}$, containing questions on symmetry, firmness and satisfaction. Further, we added some questions on neuropathy to the PROMquestionnaire, conform the CTCAE $\vee 4.0$ score. All toxicity scores were thus reported on a four-point scale, with exception of patient reported satisfaction: this was scored on a five-point scale.

\section{Oncological outcome}

Data regarding locoregional recurrence and distant metastases were retrieved from the medical records.

To assess patient reported disease status, questions on whether the disease had recurred, and if so when and where, were included in the questionnaire.

\section{Statistical analysis}

Descriptive statistics were used to describe the study population and to give an overview of the measured endpoints. For continuous variables this included the mean, standard deviation and range. Secondly, we compared the data from the questionnaires with the data obtained at the OCLO using ttests or Chi-square tests, with the data-source (OCLO or questionnaire) being the independent variable, and the corresponding outcome as the dependent data. When comparing the cosmetic outcome scores of the questionnaires with corresponding items scored on the OCLO, we divided the four category answers in two scales. In the questionnaire, cosmetic outcome was scored on a fivepoint scale: for this item very satisfied and satisfied were taken together as 'satisfactory', and the three worst categories (not dissatisfied, dissatisfied and very dissatisfied) were merged together as 'not satisfactory'.

Concerning lymphedema and shoulder function, we compared the treated side with the untreated side. In case of a history of bilateral breast carcinoma, patients were removed from the analysis. Both shoulder function and lymphedema were converted to a 4-point scale.

Concerning oncological outcome, patient reported disease recurrence was compared with data from the patient files. Five- and 10-year actuarial survival rates were determined based on the data retrieved from the patient files.

Finally, we determined the percentage of concordance for patients of whom both OCLO data and questionnaires were available. For this purpose, we used the full scales. In case of a 5-point scale, two categories were taken together to create a logical 4-point scale. For instance, in case of lymphedema, a measured arm circumference of less than $95 \%$ and a normal arm circumference (95\%-105\%) were pooled together and set equal to "I do not suffer from lymphedema". We calculated percentage of 
full agreement, but we also explored the non-concordant cases. To assess whether late toxicity would be underestimated using questionnaires only, the number of patients with a toxicity score at the OCLO of 2 or more degrees worse than in the questionnaire was assessed. A limit of 5\% was regarded as acceptable and a one-proportion z-test was performed to test exceeding this limit.

\section{Results}

The study population consisted of 1029 patients who received adjuvant radiotherapy for primary breast cancer between 2002 and 2005. Patient files were available for all these patients (Fig. 1 and Table 1). 686 of them were alive and invited to visit the OCLO and fill out questionnaires. 249 patients (36\%) agreed to visit the OCLO of whom 244 also answered the questionnaires. In total, 341 (50\%) patients filled in the questionnaire (Fig. 1).

Patient and treatment characteristics are given in Table 1; as indicated by the p-value, the OCLO study population differed from patients not visiting the OCLO with respect to age, stage, type of surgery and type of treatment.

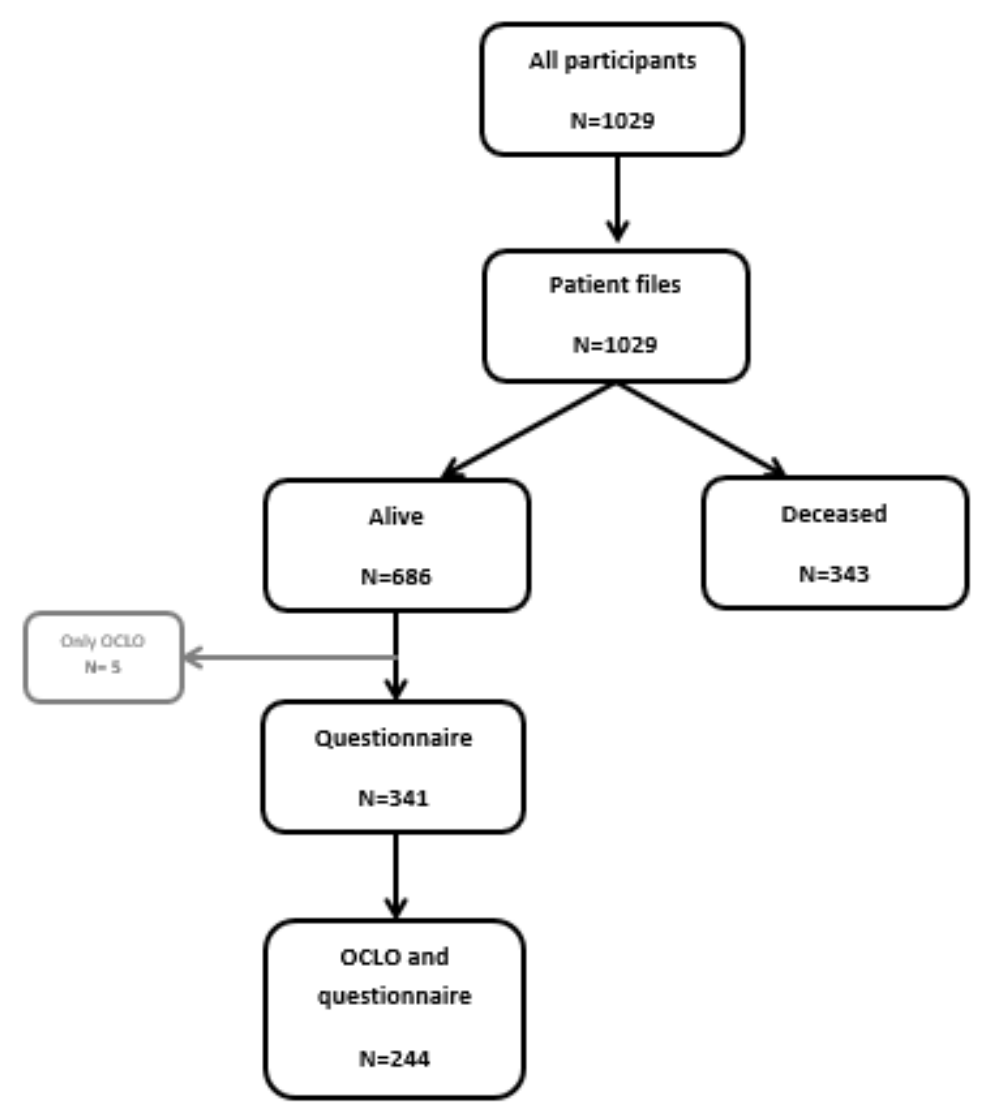

Figure 1. Overview of data analysed in the outpatient clinic for late outcome (OCLO). The five patients who visited the OCLO but did not complete the questionnaire, were excluded from the toxicity analysis and analysed in the 'patient file only' group. 


\begin{tabular}{|c|c|c|c|c|c|}
\hline & All patients & $\begin{array}{c}\text { OCLO, } \\
\text { questionnaire } \\
\text { and patient } \\
\text { file }\end{array}$ & $\begin{array}{l}\text { No OCLO, only } \\
\text { questionnaire } \\
\text { and patient } \\
\text { file }\end{array}$ & $\begin{array}{l}\text { Only patient } \\
\text { file }\end{array}$ & $p$-value \\
\hline Number of patients & 1029 & 244 & 97 & 688 & \\
\hline Mean age (SD) & $59(12.2)$ & $54(8.5)$ & $57(10.5)$ & $61(13.0)$ & 0.005 \\
\hline Stage & & & & & 0.005 \\
\hline Stage 0 & $26(2.5 \%)$ & 4 (1.6\%) & $6(6.2 \%)$ & $16(2.3 \%)$ & \\
\hline Stage I & $432(42 \%)$ & $125(51.2 \%)$ & $42(53.3 \%)$ & $265(38.5 \%)$ & \\
\hline Stage II & 355 (34.3\%) & $87(35.7 \%)$ & $36(37.1 \%)$ & $232(33.7 \%)$ & \\
\hline Stage III & $141(13.7 \%)$ & $22(9.0 \%)$ & $8(8.2 \%)$ & $111(16.1 \%)$ & \\
\hline Stage IV & $2(0.2 \%)$ & NA & NA & $2(0.3 \%)$ & \\
\hline unknown & $73(7.1 \%)$ & $6(2.5 \%)$ & $5(5.2 \%)$ & $62(9.0 \%)$ & \\
\hline Surgery & & & & & 0.05 \\
\hline Mastectomy & 125 (12.1\%) & $28(11.5 \%)$ & 5 (5.2\%) & $92(13.4 \%)$ & \\
\hline Breast conserving surgery & 887 (86.2\%) & $213(87.3 \%)$ & $92(94.8 \%)$ & $582(84.6 \%)$ & \\
\hline Unknown & $17(1.7 \%)$ & $3(1.2 \%)$ & NA & $14(2.0 \%)$ & \\
\hline $\begin{array}{l}\text { Systemic treatment } \\
\text { (chemotherapy) }\end{array}$ & & & & & 0.26 \\
\hline Chemotherapy & 443 (43.1\%) & $118(48.4 \%)$ & $40(41.2 \%)$ & 285 (41.4\%) & \\
\hline No chemotherapy & 557 (54.1\%) & $124(50.8 \%)$ & $57(58.8 \%)$ & 376 (54.7\%) & \\
\hline unknown & $29(2.8 \%)$ & $2(0.8 \%)$ & NA & $27(3.9 \%)$ & \\
\hline $\begin{array}{l}\text { Systemic treatment } \\
\text { (endocrine therapy) }\end{array}$ & & & & & 0.10 \\
\hline Endocrine therapy & $389(37.8 \%)$ & $106(43.3 \%)$ & $31(32.0 \%)$ & $252(36.6 \%)$ & \\
\hline No endocrine therapy & 595 (57.8\%) & $132(54.1 \%)$ & $65(67.0 \%)$ & $398(57.8 \%)$ & \\
\hline Unknown & $45(4.4 \%)$ & $6(2.5 \%)$ & $1(1.0 \%)$ & $38(5.5 \%)$ & \\
\hline Treatment: & & & & & 0.002 \\
\hline $\begin{array}{l}\text { Only surgery and } \\
\text { radiotherapy }\end{array}$ & $434(42.2 \%)$ & $105(43.0 \%)$ & 49 (50.5\%) & $280(40.7 \%)$ & \\
\hline $\begin{array}{l}\text { Surgery, radiotherapy and } \\
\text { chemotherapy }\end{array}$ & $160(15.5 \%)$ & $27(11.1 \%)$ & $16(16.5 \%)$ & 117 (17.0\%) & \\
\hline $\begin{array}{l}\text { Surgery, radiotherapy and } \\
\text { endocrine therapy }\end{array}$ & $113(11.0 \%)$ & $18(7.4 \%)$ & $8(8.2 \%)$ & 87 (12.6\%) & \\
\hline $\begin{array}{l}\text { Surgery, radiotherapy, } \\
\text { chemotherapy and } \\
\text { endocrine therapy }\end{array}$ & 275 (26.7\%) & $88(36.1 \%)$ & $23(23.7 \%)$ & $164(23.8 \%)$ & \\
\hline Unknown & $47(4.6 \%)$ & $6(2.5 \%)$ & $1(1.0 \%)$ & $40(5.8 \%)$ & \\
\hline
\end{tabular}

Table 1. Patient and treatment characteristics for the different patient groups. 
Toxicity scored by clinicians at the OCLO and by patients in the PROM-questionnaire (presented in all patients returning the PROM-questionnaire and only the patients visiting the OCLO) are shown in Table 2. The patient reported incidence of all side-effects except any pain was at a group level higher than reported at the OCLO with differences in incidence varying from $2 \%$ for severe pain, to $19 \%$ for fatigue or any lymphedema (Table $\mathbf{2}$ and Figure $\mathbf{2}$ ).

At an individual level, the average concordance rate in toxicity scores between PROMs and the OCLO was $60 \%$ (Table 3). The agreement was lowest for fibrosis (40.5\%) and cosmetic outcome (46.6\%), and the highest for edema, shoulder function and neuropathy (63.7-67.5\%).

Concerning the patients with non-concordant scores, $26.3 \%$ (17.8\%-39.5\%) of the patients reported higher levels of toxicity than the clinician did, whereas in $13.3 \%$ (7.1\%-20.0\%) the clinician at the OCLO reported higher levels. For example, cosmetic outcome was scored worse by the clinician than by the PROMs questionnaire in $19.1 \%$, while in $34.4 \%$ the patient reported worse outcome than scored at the OCLO (Table 3).

In $6.7 \%$ patients reported $\mathrm{a} \geq 2$ degrees higher toxicity than scored at the OCLO, and in $2.1 \%$ clinicians reported a $\geq 2$ degrees worse toxicity at the OCLO than patients in the questionnaire. For all toxicities, $<5 \%$ of patients underestimated their toxicity with $\geq 2$ degrees compared to the clinician. However, statistical analysis showed that we could not exclude that the population percentage with underestimation of their toxicity with $\geq 2$ degrees was larger than $5 \%$, for fibrosis, shoulder function, lymphedema (lower arm) and motor neuropathy.

With respect to oncological outcome, we found that of the 1029 patients, 686 patients (67\%) were still alive at about 10 years after treatment. 5 - and 10 -year actuarial overall survival (OS) were $84.6 \%$ and $67.9 \%$ respectively (Table 4). Locoregional control at 10 years was $91.8 \%$ for all patients. Patients visiting the OCLO had a better locoregional control than patients who did not $(97.5 \%$ vs $88.1 \%$ $p<0.001)$. The same was observed for disease free survival (DFS): 10 year DFS for all patients was $72.5 \%$, and $93.9 \%$ for the OCLO group compared to $60.2 \%(p<0.001)$ for patients who did not visit the OCLO (Table 4).

Regarding concordance in oncological outcome, 21 patients had a recurrence based on data of the OCLO and patient files. In two of these patients, disease recurrence was not mentioned in the questionnaire. In 9 cases, patients reported disease recurrence while patient files did not (3\%). Of these 9 patients, 6 patients had developed a second primary tumor, either in the ipsilateral breast ( $\mathrm{N}$ $=1$ different histology), the contralateral breast $(\mathrm{N}=3)$, or elsewhere $(\mathrm{N}=2)$. Due to low number of events significance levels could not be assessed. 


\begin{tabular}{|c|c|c|c|c|c|c|}
\hline & \multicolumn{2}{|c|}{$\begin{array}{l}\text { Outcome recorded by } \\
\text { clinician at the OCLO } \\
\qquad(N=244)\end{array}$} & \multicolumn{2}{|c|}{$\begin{array}{l}\text { Outcome recorded by } \\
\text { patients using } \\
\text { questionnaires, and } \\
\text { also visiting the OCLO } \\
\text { (N=244) }\end{array}$} & \multicolumn{2}{|c|}{$\begin{array}{l}\text { Outcome recorded by } \\
\text { all patients using } \\
\text { questionnaires } \\
(\mathrm{N}=341)\end{array}$} \\
\hline & $\mathrm{N} /$ total & $\%$ & $\mathrm{~N} /$ total & $\%$ & $\mathrm{~N} /$ total & $\%$ \\
\hline $\begin{array}{l}\text { Satisfied cosmetic } \\
\text { outcome }\end{array}$ & $124 / 202$ & $61 \%$ & $107 / 189$ & $57 \%$ & $168 / 282$ & $60 \%$ \\
\hline $\begin{array}{l}\text { Fibrosis whole breast } \\
\text { severe }\end{array}$ & $5 / 211$ & $2 \%$ & $21 / 195$ & $11 \%$ & $28 / 278$ & $10 \%$ \\
\hline $\begin{array}{l}\text { Fibrosis whole breast } \\
\text { moderate / severe }\end{array}$ & $44 / 211$ & $21 \%$ & $66 / 195$ & $34 \%$ & $85 / 283$ & $30 \%$ \\
\hline $\begin{array}{l}\text { Pain in breast area } \\
\text { any }\end{array}$ & $120 / 243$ & $49 \%$ & $110 / 236$ & $47 \%$ & $137 / 332$ & $41 \%$ \\
\hline $\begin{array}{l}\text { Pain in breast area } \\
\text { more than a little }\end{array}$ & $24 / 243$ & $10 \%$ & $33 / 236$ & $14 \%$ & $41 / 332$ & $12 \%$ \\
\hline $\begin{array}{l}\text { Pain in breast area } \\
\text { severe }\end{array}$ & $3 / 243$ & $1 \%$ & $7 / 236$ & $3 \%$ & $9 / 332$ & $3 \%$ \\
\hline $\begin{array}{l}\text { Lymphedema } \\
\text { any }\end{array}$ & $20 / 165$ & $12 \%$ & $49 / 156$ & $31 \%$ & $98 / 324$ & $30 \%$ \\
\hline $\begin{array}{l}\text { Impaired shoulder } \\
\text { function * }\end{array}$ & $\begin{array}{c}18-50 \\
/ 220\end{array}$ & $8-22 \%$ & $68 / 214$ & $32 \%$ & $111 / 332$ & $33 \%$ \\
\hline $\begin{array}{l}\text { Neuropathy-sensory } \\
\text { Any sign }\end{array}$ & $73 / 243$ & $30 \%$ & $95 / 229$ & $41 \%$ & $135 / 323$ & $42 \%$ \\
\hline $\begin{array}{l}\text { Neuropathy-sensory } \\
\text { Impaired function }\end{array}$ & $19 / 243$ & $8 \%$ & $44 / 229$ & $19 \%$ & $57 / 323$ & $18 \%$ \\
\hline $\begin{array}{l}\text { Neuropathy-motor } \\
\text { Any sign }\end{array}$ & $66 / 243$ & $27 \%$ & $88 / 234$ & $38 \%$ & $125 / 331$ & $38 \%$ \\
\hline $\begin{array}{l}\text { Neuropathy-motor } \\
\text { Impaired function }\end{array}$ & $37 / 243$ & $15 \%$ & $49 / 234$ & $21 \%$ & $72 / 331$ & $22 \%$ \\
\hline $\begin{array}{l}\text { Fatigue } \\
\text { any }\end{array}$ & $112 / 243$ & $46 \%$ & $153 / 237$ & $65 \%$ & $220 / 333$ & $66 \%$ \\
\hline $\begin{array}{l}\text { Fatigue } \\
\text { more than a little }\end{array}$ & $48 / 243$ & $20 \%$ & $93 / 237$ & $25 \%$ & $80 / 333$ & $24 \%$ \\
\hline
\end{tabular}

Table 2. Toxicity scored by patient at the questionnaire and measured or asked at the outpatient clinic for late outcome (OCLO). Patients who underwent a mastectomy did not report on fibrosis and cosmetic outcome. * Shoulder function was distracted from six different shoulder excursions, therefore we only mentioned the lowest and the highest incidence of the six measures of impaired shoulder function. 

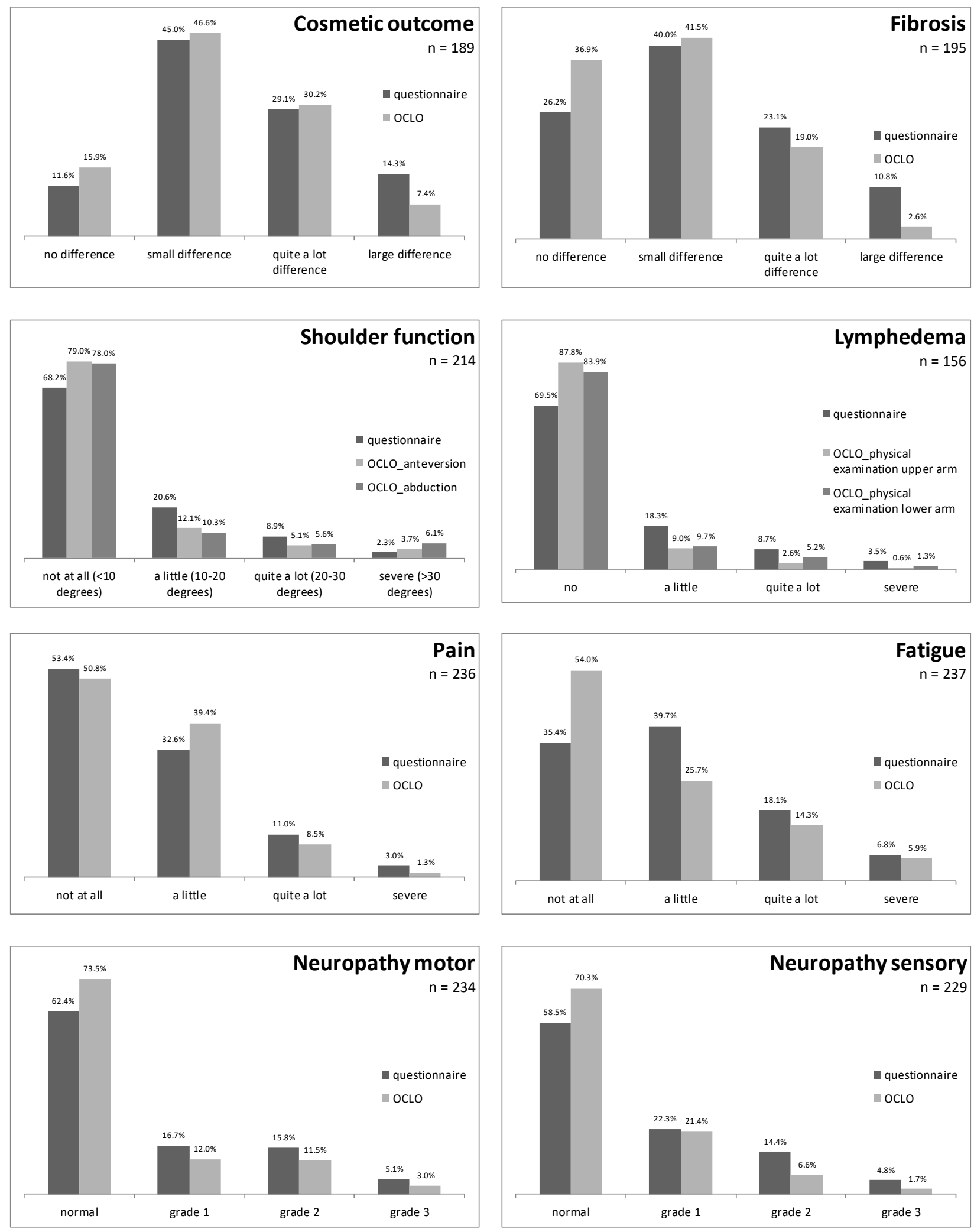

Figure 2. Comparison between patient questionnaire and clinician assessment of late toxicity at 10 years of patients visited the outpatient clinic of late outcome (OCLO). The data are limited to those patients of whom both the score at the OCLO and on the questionnaire were available. 


\begin{tabular}{lcccc|c|cc}
\hline & $\mathrm{N}$ & OCLO $=\mathrm{Q}$ & OCLO $>\mathrm{Q}$ & OCLO $<$ & $\begin{array}{c}\text { OCLO }>\mathrm{Q} \\
(\geq 2)\end{array}$ & $\begin{array}{c}\text { OCLO } \\
(\leq 2)\end{array}$ & p-value* \\
\hline $\begin{array}{l}\text { Cosmetic } \\
\text { outcome }\end{array}$ & 189 & $46.6 \%$ & $19.1 \%$ & $34.4 \%$ & $1.6 \%$ & $3.2 \%$ & 0.03 \\
\hline $\begin{array}{l}\text { Fibrosis (whole } \\
\text { breast) }\end{array}$ & 195 & $40.5 \%$ & $20.0 \%$ & $39.5 \%$ & $4.1 \%$ & $12.3 \%$ & 0.56 \\
\hline $\begin{array}{l}\text { Pain in irradiated } \\
\text { area }\end{array}$ & 236 & $65.7 \%$ & $16.5 \%$ & $17.8 \%$ & $1.3 \%$ & $3.0 \%$ & $<0.01$ \\
\hline $\begin{array}{l}\text { Shoulder function } \\
\text { (abduction) }\end{array}$ & 214 & $65.9 \%$ & $14.5 \%$ & $19.6 \%$ & $4.7 \%$ & $4.7 \%$ & 0.84 \\
\hline $\begin{array}{l}\text { Shoulder function } \\
\text { (anteversion) }\end{array}$ & 214 & $65.9 \%$ & $12.6 \%$ & $21.5 \%$ & $2.8 \%$ & $5.1 \%$ & 0.14 \\
\hline $\begin{array}{l}\text { Lymphedema } \\
\text { (Upper arm) }\end{array}$ & 156 & $66.7 \%$ & $7.1 \%$ & $26.3 \%$ & $0.0 \%$ & $8.9 \%$ & 0.004 \\
\hline $\begin{array}{l}\text { Lymphedema } \\
\text { (Lower arm) }\end{array}$ & 155 & $63.9 \%$ & $12.3 \%$ & $23.9 \%$ & $2.6 \%$ & $9.7 \%$ & 0.17 \\
\hline $\begin{array}{l}\text { Neuropathy } \\
\text { (sensory) }\end{array}$ & 229 & $63.7 \%$ & $9.6 \%$ & $26.6 \%$ & $0.9 \%$ & $8.3 \%$ & 0.004 \\
\hline $\begin{array}{l}\text { Neuropathy } \\
\text { (motor) }\end{array}$ & 234 & $67.5 \%$ & $10.7 \%$ & $21.8 \%$ & $3.0 \%$ & $9.4 \%$ & 0.16 \\
\hline \begin{tabular}{l} 
Fatigue \\
\hline \begin{tabular}{l} 
Mean \\
\hline
\end{tabular}
\end{tabular} & 237 & $57.8 \%$ & $10.5 \%$ & $31.6 \%$ & $0.0 \%$ & $2.5 \%$ & $<0.001$ \\
\hline
\end{tabular}

Table 3. Concordance of toxicity reported at the outpatient clinic for late outcome (OCLO) and reported in the questionnaire $(Q)$.

OCLO = $\mathrm{Q}$ means a full agreement between the grade of toxicity scored at the OCLO by the physician/trial nurse and the grade of toxicity reported by the patient in the questionnaire.

OCLO > Q means that at the OCLO higher grades of toxicity were scored by the physician/trial nurse than patients reported in the questionnaire. In case of OCLO $<Q$, patients reported higher levels of toxicity in the questionnaire than scored at the OCLO.

$(\geq 2)$ levels implies that the difference is at least 2 degrees (for instance, patient reports excellent cosmesis, but at the OCLO moderate or poor cosmetic outcome is scored).

In the marked row the difference is at least 2 degrees worse reported at the OCLO as reported in the questionnaire.

* $p$-value from z-test for a single proportion with null hypothesis value of $5 \%$ calculated for OCLO $>Q$ $(\geq 2)$. P-values $>0.05$ mean that the null-hypothesis, that the population percentage is $>5 \%$, cannot be rejected. 


\begin{tabular}{|c|c|c|c|c|}
\hline & $\begin{array}{c}\mathrm{N} \\
\mathrm{N} \text { (missing) } \\
\end{array}$ & 5 -year $(95 \% \mathrm{Cl})$ & 10 -year $(95 \% \mathrm{Cl})$ & $\begin{array}{c}p- \\
\text { value }\end{array}$ \\
\hline \multicolumn{5}{|c|}{ Overall survival } \\
\hline All patients & $1026(3)$ & $84.6(82.4-86.8)$ & $67.9(65.0-70.8)$ & \\
\hline Only patient file & $685(3)$ & $76.6(73.4-79.8)$ & $49.3(45.1-53.5)$ & \\
\hline \multicolumn{5}{|c|}{ Locoregional recurrence free survival } \\
\hline All patients & $823(206)$ & $95.9(94.5-97.3)$ & $91.8(89.6-94.0)$ & \multirow{4}{*}{$<0.001$} \\
\hline Visited OCLO & $244(0)$ & $98.8(97.4-100.0)$ & $97.5(95.5-99.5)$ & \\
\hline Not visited OCLO & $579(206)$ & $94.6(92.6-96.6)$ & $88.1(85.2-91.4)$ & \\
\hline \multirow[t]{2}{*}{$\begin{array}{l}\text { Questionnaire } \\
\text { (OCLO and no OCLO) } \\
\end{array}$} & $341(0)$ & $97.9(96.3-99.5)$ & $95.6(93.4-97.8)$ & \\
\hline & \multicolumn{2}{|c|}{ Disease free survival } & & \\
\hline All patients & $924(105)$ & $83.9(81.3-86.5)$ & $72.1(68.7-75.5)$ & \multirow{5}{*}{$<0.001$} \\
\hline Visited OCLO & $244(0)$ & $97.5(95.5-99.5)$ & $93.9(90.9-96.9)$ & \\
\hline Not visited OCLO & $680(105)$ & $78.4(75.1-81.7)$ & $60.2(55.5-64.9)$ & \\
\hline $\begin{array}{l}\text { Reported by patients } \\
\text { visited OCLO }\end{array}$ & $228(16)$ & $95.6(92.8-98.4)$ & $91.2(87.4-95.0)$ & \\
\hline $\begin{array}{l}\text { Questionnaire } \\
\text { (OCLO and no OCLO) }\end{array}$ & $341(0)$ & $97.0(95.2-98.8)$ & $92.0(88.8-95.2)$ & \\
\hline
\end{tabular}

Table 4. Overall survival, locoregional recurrence free survival, metastasis free survival and disease free survival for the separate groups. Overall survival for the OCLO/questionnaire group is not shown, as it is $100 \%$.

\section{Discussion}

We showed that, at a group level, PROMs do not underestimate late toxicity, such that they can safely be used to monitor quality of care or changes of treatment protocols. In addition, we found that when looking at individual scores, questionnaires and OCLO were non-concordant in 40\%: in 13\% side effects were scored more severe at the OCLO, and in $26 \%$ the side effects were scored more severe when using the questionnaires. This may raise the question whether PROMs can be used to identify patients who need special attention for late toxicity. Although $<5 \%$ of patients underestimated their toxicity with $\geq 2$ degrees compared to the clinician, statistical analysis showed that for fibrosis, shoulder function, lymphedema (lower arm) and motor neuropathy this threshold may be exceeded. Finally, we found only a low number of recurrences in the questionnaire population, such that no firm conclusions can be drawn on the use of PROMs to assess oncological outcome. 


\section{Interpretation of the results and comparison with literature}

In our study, the toxicity measured at a group level using PROMs was somewhat higher than reported by the clinician at the OCLO, which corresponds to the data of the START trial, where also somewhat higher levels of toxicity were found in the PROMs. The same was observed in the PORTEC- 3 trial for endometrial carcinoma ${ }^{14}$. In contrast, in the Cambridge Breast Intensity-modulated Radiotherapy trial $^{7}$ physicians scored higher rates of late toxicity than the patients did, which they ascribed to adaptation of patients to their health situation. This might also explain the possibility of missing severe toxicity in case of fibrosis, shoulder function, lymphedema (lower arm) and neuropathy (motor) in this study.

With respect to comparing the data at an individual level, our concordance rates are in line with other studies where PROMs are compared with doctor-reported outcome data after radiotherapy for breast cancer. Both the START trials ${ }^{8}$ and the Cambridge Breast Intensity-modulated Radiotherapy (IMRT) trial $^{7}$ showed levels of agreement between $39 \%$ and $86 \%$ at 5 years, comparable to our findings at ten years (41-67\%).

Since the agreement between PROMs and physician reported outcome is generally low, the question arises which reported outcome is 'true' or most useful. Whether PROMs are sufficiently reliable depends on the purpose of outcome registration: A) When toxicity is registered with the objective to identify patients who need extra attention, we need a tool that defines the burden of toxicity to patient, for which PROMs are very suitable ${ }^{7,15}$, such that we conclude that we can use PROMs for this purpose, in spite of the low concordance rate; B) When outcome registration is used to monitor quality of care, and changes in treatment protocols, the START trials ${ }^{8}$ showed that PROMs are sensitive enough to detect differences. However, since we found that fibrosis, shoulder function, lymphedema (lower arm) and motor neuropathy may be underestimated with $\geq 2$ degrees in $>5 \%$ of the population, we need to interpret the data for this purpose with some caution; C) When outcome registration is however used to identify clues on how to improve outcome, more objective outcome registration might be needed. For cosmetic outcome for instance, digital photographs can be used for that purpose $^{16}$.

With respect to oncological outcome, we can only compare the locoregional recurrence rate with literature, since we are not aware of data presenting OS and DFS of patients selected by the fact that they were treated with adjuvant radiotherapy. We found a locoregional recurrence rate of less than $1 \%$ per year, which is comparable with literature regarding the same period of time ${ }^{17}$. Two of 21 patients with recurrent disease would have been missed if questionnaires only had been used, and nine patients reported a 'false' disease recurrence. This latter finding is considered less problematic, 
since a reported recurrence can actively be verified. However, due to the low response rate, we cannot rely on questionnaires only to assess oncological outcome.

\section{Study limitations}

A limitation of this study is the relatively low number of patients that was willing to visit the OCLO $(249 / 686=36 \%)$ and to fill out the questionnaires $(341 / 686=50 \%)$, which could raise questions on the representativeness of the study population of responding patients.

The oncological outcome of patients visiting the OCLO or filling out questionnaires was better than patients not responding at all, suggesting that disease free patients were more inclined to respond than patients with a recurrence.

Obviously, patients filling in the questionnaire or visiting the OCLO, were not representative for the whole patient population regarding (locoregional) survival. The same holds probably true for the absolute incidence of toxicity. Since the percentage of patients willing to visit the OCLO was low, we added the possibility to fill in why they were not willing to come to the OCLO. The main reasons were the absence of complaints, followed by a too far travel distance. However, it cannot be excluded that for patients who did not respond at all, toxicity could be worse or better.

Nevertheless, despite possibly doubtful representativeness of our patient population, one can assume that the concordance between PROMs and late toxicity scored by the clinician would be the same for patients not visiting the OCLO. Consequently, although we have to be cautious to interpret the results with respect to the absolute toxicity levels, we consider the analyses of concordance levels reliable. Another limitation is the fact that we do not have baseline PROMs but only have PROM-data at 10year follow up. Therefore, changes over time cannot be described.

\section{Consequences for clinical practice}

Our institute recently started using PROMs on a regular base, beginning before the start of radiotherapy to determine a baseline score. Subsequently, patients receive a questionnaire 3 weeks and 3, 6 and 12 months after treatment, and thereafter yearly until at least 10 years after treatment ${ }^{18}$ (see supplementary file). Acute toxicity is also scored by the physician according to CTCAE v4.0 before, during and until 4-6 weeks after treatment. PROMs are screened by an employee to identify toxicity scores $\geq$ grade 3 , which are then immediately reported to the treating radiation oncologist for evaluation, who, if needed, undertakes action. The PROMs also contain validated utility and quality of life questionnaires, such as EQ5D, QLQ-C30 and tumor specific EORTC modules in accordance with the ICHOM outcome sets ${ }^{19}$, to facilitate benchmarking in the future. For this purpose, data on treatment and patient variables, including comorbidity, are systematically collected as well. 


\section{Conclusion}

The current study shows that patients are more willing to return a questionnaire than visiting the OCLO and provides us sufficient information that one can rely on PROMs for the recording of late sideeffects on a group level, and for identifying patients who need attention because of severe complaints. Therefore, by using PROMs, the patient can be saved a visit to the hospital. 


\section{References}

1. Desantis C, Ma J, Bryan L, Jemal A. Breast Cancer Statistics , 2013. CA Cancer J Clin. 2014;64:52-62. doi:10.3322/caac.21203.

2. Ewertz $M$, Jensen $A B, M$. E, A.B. J. Late effects of breast cancer treatment and potentials for rehabilitation. Acta Oncol (Madr). 2011;50(2):187-193. doi:10.3109/0284186X.2010.533190.

3. Friese CR, Harrison JM, Janz NK, et al. Treatment-associated toxicities reported by patients with early-stage invasive breast cancer. Cancer. 2017;In press:1-10. doi:10.1002/cncr.30547.

4. Grunfeld E, Levine MN, Julian JA, et al. Randomized trial of long-term follow-up for earlystage breast cancer: A comparison of family physician versus specialist care. J Clin Oncol. 2006;24(6):848-855. doi:10.1200/JCO.2005.03.2235.

5. Kimman ML, Bloebaum MM, Dirksen CD, Houben RM, Lambin P, Boersma L. Patient satisfaction with nurse-led telephone follow-up after curative treatment for breast cancer. BMC Cancer. 2010;10:174. doi:10.1186/1471-2407-10-174.

6. Koinberg IL, Fridlund B, Engholm GB, Holmberg L. Nurse-led follow-up on demand or by a physician after breast cancer surgery: A randomised study. Eur J Oncol Nurs. 2004;8(2):109117. doi:10.1016/j.ejon.2003.12.005.

7. Mukesh MB, Qian W, Wah Hak CC, et al. The Cambridge Breast Intensity-modulated Radiotherapy Trial: Comparison of Clinician- versus Patient-reported Outcomes. Clin Oncol. 2016;28(6):354-364. doi:10.1016/j.clon.2016.02.011.

8. Haviland JS, Hopwood P, Mills J, Sydenham M, Bliss JM, Yarnold JR. Do Patient-reported Outcome Measures Agree with Clinical and Photographic Assessments of Normal Tissue Effects after Breast Radiotherapy? The Experience of the Standardisation of Breast Radiotherapy (START) Trials in Early Breast Cancer. Clin Oncol. 2016;28(6):345-353. doi:10.1016/j.clon.2016.01.011.

9. Harris JR, Levene MB, Svensson G, Hellman S. Analysis of cosmetic results following primary radiation therapy for stages I and II carcinoma of the breast. Int J Radiat Oncol. 1979;5(2):257-261. doi:10.1016/0360-3016(79)90729-6.

10. Donker M, Tlenhoven van G, Straver M, et al. NIH Public Access. Lancet Oncol. 2015;15(12):1303-1310. doi:10.1016/S1470-2045(14)70460-7.Radiotherapy.

11. Sprangers MAG, Groenvald M, Arraras JI, et al. The European Organization for Research and Treatment of Cancer Breast Cancer - specific quality-of-life questionnaire module: first results from a three-country field study. J Clin Oncol. 1996;14(10):2756-2768. doi:10.1200/jco.1996.14.10.2756.

12. J NJ. EORTC QLQ-BR23 and FACT-B for the assessment of quality of life in patients with breast cancer: a literature review. J Comp Eff Res. 4(2):157-166.

13. Sneeuw KCA et al. 1.Cosmetic and functional outcomes of breast conserving treatment for early stage breast cancer. 1 . Comparison of patients' ratings, observers' ratings and objective assessments. Radiother Oncol. 1992;25(3):153-159.

14. de Boer SM, Powell ME, Mileshkin L, et al. Toxicity and quality of life after adjuvant chemoradiotherapy versus radiotherapy alone for women with high-risk endometrial cancer (PORTEC-3): an open-label, multicentre, randomised, phase 3 trial. Lancet Oncol. 2016;17(8):1114-1126. doi:10.1016/S1470-2045(16)30120-6.

15. Faithfull S, Lemanska A, Chen T. Patient-reported Outcome Measures in Radiotherapy: 
Clinical Advances and Research Opportunities in Measurement for Survivorship. Clin Oncol. 2015;27(11):679-685. doi:10.1016/j.clon.2015.07.007.

16. Cardoso MJ, Cardoso J, Amaral N, et al. Turning subjective into objective: the BCCT.core software for evaluation of cosmetic results in breast cancer conservative treatment. Breast. 2007;16(5):456-461. doi:10.1016/j.breast.2007.05.002.

17. Bartelink $\mathrm{H}$, Maingon $\mathrm{P}$, Poortmans $\mathrm{P}$, et al. Whole-breast irradiation with or without a boost for patients treated with breast-conserving surgery for early breast cancer : 20-year follow-up of a randomised phase 3 trial. Lancet Oncol. 2015;16:47-56. doi:10.1016/S14702045(14)71156-8.

18. Boersma L, Nijsten I, Brouns M, Dekker A, Smits K. Systematic registration of outcome in a radiotherapy institute. Eur J Cancer. 2017;72:S139. doi:10.1016/S0959-8049(17)30531-2.

19. Ong WL, Schouwenburg MG, van Bommel ACM, et al. A Standard Set of Value-Based PatientCentered Outcomes for Breast Cancer. JAMA Oncol. 2016;3(5).

doi:10.1001/jamaoncol.2016.4851. 
Chapter 6

General Discussion 


\section{General discussion}

A growing number of breast cancer patients can be cured and consequently patients live longer after treatment ${ }^{1,2}$. Therefore, it is important to have knowledge about the severity and incidence of various late side effects of treatment and their severity. This knowledge is not only required to find clues for mitigation late side effects, the information is also required for shared decision making (SDM) on choosing for radiotherapy yes or no.

In this thesis we mainly focussed on the cosmetic analysis of the Young Boost Trial (YBT). We determined which factors are important for patient reported cosmetic outcome, fibrosis and cosmetic outcome. Further, we report on an easy but reproducible and affordable breath hold manoeuvre to reduce the dose to the heart (Voluntary moderately Deep Inspiration Breath Hold, vmDIBH), to mitigate radiation-induced cardiac injury. At last we investigated whether patient reported outcome measures (PROMS) are sufficiently reliable to record late outcome.

\section{Cosmesis}

Previous studies showed increased fibrosis ${ }^{3}$ and decreased cosmetic outcome ${ }^{4}$ following breast radiation therapy. In the YBT only $63 \%$ of patients who received a 16 Gy boost found their cosmetic outcome satisfactory. This number decreases to $53 \%$ in case a $26 \mathrm{~Gy}$ boost was given ${ }^{5}$. We were able to define the distance from nipple to inframammary fold and the length of the breast contour as the most important symmetry features for a patient to like her aesthetic outcome ${ }^{6}$. Additionally, the chance for a patient to dislike the cosmetic outcome increases with increasing severity of fibrosis ${ }^{6}$. Further, in our analysis, a 26 Gy boost dose compared to a $16 \mathrm{~Gy}$ boost dose, poor cosmesis before start radiation treatment (baseline cosmesis), a photon boost instead of an electron boost, a large boost volume and adjuvant chemotherapy were defined as risk factors for worse cosmetic outcome ${ }^{5}$. From the literature many other risk factors for cosmetic outcome are known such as smoking ${ }^{7}$, dose homogeneity ${ }^{8}$, breast size ${ }^{7,9}$, supine instead of prone position ${ }^{10}$, total dose (hypofractionation) ${ }^{11,12}$, dose $\max ^{13-15}$, excision volume ${ }^{16,17}$, tumour size ${ }^{16}$, re-excision ${ }^{18}$, oncoplastic surgery ${ }^{19}$, location of the tumour $^{4,9,16}$ and postoperative complications ${ }^{7,9}$. Some of these factors cannot be influenced, for example breast size or tumour location. In some cases, there is a strong indication for chemotherapy. On the other hand, other (radiation associated) factors as dose homogeneity, maximum dose, and total dose (use of hypofractionation) and perhaps boost volume and/or boost dose might be influenced. However, despite the fact we know more about potential risk factors, there is still a lack of knowledge how to deal with them. For instance, it is unknown what we should consider as the 
optimal radiation plan. Is it better to plan the boost dose with the tangential fields to lower the dose in the heart and lungs, or is an extra beam or arc preferred to deliver the boost dose with the consequence a slightly higher dose into the heart and/or lungs? Except in extreme cases, there is no single best answer to these questions. The answer is a balance between the probability and severity of avoidable side effects, the chance for achieving tumour control and the preferences of the patient. Further, the use of oncoplastic surgery is increasingly becoming part of routine breast cancer surgical management ${ }^{20,21}$. Although the aim of oncoplastic surgery is to improve aesthetic outcome without compromising oncological safety ${ }^{21}$, for now there are no publications showing that oncoplastic surgery is actually leading to a better cosmetic outcome ${ }^{20,22}$. Lansu et al analysed a subgroup of the YBT (single centre) and found that patients who underwent oncoplastic surgery scored even a significantly worse cosmetic outcome, based on the objective BCCT.core tool ${ }^{19}$. However, this analysis was performed after only one year follow up. A possible explanation for this worse cosmetic outcome could be that the gain in cosmetic outcome achieved by oncoplastic surgery is counterbalanced by the radiation treatment. Oncoplastic surgery might result in larger amount of seroma, although there is no literature to support or disprove this hypothesis. Furthermore, tumour bed delineation for radiotherapy will be more difficult due to large mammary gland translations, rotations or excisions, which could lead to larger boost volumes. Boost volume is, as we showed, an important risk factor for worse cosmetic outcome. Unfortunately, no results of randomized controlled trials, comparing oncoplastic surgery with standard lumpectomy, are yet available. The same is true for long term results after oncoplastic surgery. For now, the question remains whether or not a patient benefits from oncoplastic surgery.

\section{Prevention of heart toxicity}

In the Netherlands, an estimated number of 752.400 women suffered with cardiovascular disease, corresponding to 87 per 1000 women $^{23}$. Radiotherapy for breast cancer, i.e. exposure of the heart to ionizing radiation, increases the risk of coronary heart disease as well as cardiac mortality ${ }^{24}$ with a proportional increased rate of major coronary events by $7.4 \%$ per Gray mean heart dose ${ }^{25}$. Therefore, it is of great importance to keep the heart dose as low as possible. We showed a reproducible and affordable breath hold maneuver to reduce the dose to the heart ${ }^{26}$. This technique has been verified in the UK Heart study ${ }^{27,28}$. More controlled alternatives for voluntary breath hold are both active breathing control $(A B C)$, using a spirometry-based device, and gating ${ }^{29}$, a non-invasive, video-based system using a lightweight device placed at the surface of the patient.

All previous techniques are based on the breath hold technique, in which the heart moves away from the tangential fields. Mast et al performed a planning study and showed that with proton 
therapy dose to the heart could be reduced in the majority of the cases to almost zero, even without a breath hold ${ }^{30}$. In the Netherlands, proton therapy became just recently available, but the health insurer only reimburses treatment in selected cases. A patient is eligible to receive proton therapy in case of a clinically relevant difference in the probability to develop a certain complication between proton and photon therapy. For breast cancer, cardiac injury is for now the only endpoint included in the national indication protocol for proton therapy. The risk on acute coronary events (ACE) is estimated based on the Darby model, where the relative risk of developing ACE is applied to the Dutch incidence of ACE, resulting in a table where the risk on ACE can be estimated based on gender, age, presence of cardiovascular risk factors, and the mean heart dose ${ }^{25}$. MacDonald et al. showed that the average mean heart dose (MHD) could be limited to 0.44 Gy (range, 0.1-1.2 Gy) in patients with left sided breast cancer, treated with proton therapy ${ }^{31}$, compared to reported mean heart doses of $2.9 \pm 1.5$ Gy in photon therapy planning ${ }^{32}$. Proton therapy can thus reduce the dose to the heart and will be most appropriate for women with underlying cardiopulmonary risk factors, unfavorable chest anatomy, medial or inferior breast tumors, or in case of radiation of the internal mammary nodes ${ }^{31}$.

However, as mentioned above, no consensus concerning the optimal radiation plan exists. One might wonder if, in selected cases, a concession to the medial part of the target volume, resulting in a lower heart dose, might be acceptable, and thereby a more efficient way to spare the heart than proton therapy. Unfortunately, no outcome data concerning these concessions of the target volume exist, such that up till now it seems more reasonable to strive for optimal target coverage

In the Netherlands, cancer is the most common cause of death for women, followed by cardiovascular disease ${ }^{33}$. Women with breast cancer have a higher risk of mortality caused by cardiovascular disease than women from the general population ${ }^{34}$. These higher mortality rates can partly be explained by treatment effects, both systemic treatment since anthracycline-based chemotherapy, trastuzumab ${ }^{35,36}$ and radiation treatment ${ }^{24}$ have been reported to increase the risk of cardiovascular disease. Cheng et al. performed a literature review and reported an absolute risk increase of 76.4 cases of coronary heart disease and 125.5 cases of cardiac death per 100.000 person-years ${ }^{24}$. However, one must also be aware of the shared risk factors for cancer and cardiovascular disease. Smoking, obesity, poor diet, and physical inactivity can cause both heart disease and cancer $^{37}$. For example, a sedentary woman who introduces the recommended 150 minutes of weekly activity can reduce her breast cancer risk by $6 \%{ }^{37}$; physical activity reduces cancer mortality with $1 \%$ for each 15 minute increase in daily physical activity ${ }^{37}$. Consequently, patients at risk for cardiac morbidity and mortality should be identified and encouraged to adjust their lifestyle and quit smoking, lose weight if necessary and adopt physical exercise in their daily life. 
To optimize treatment related side effects, identification of patients with a high risk of cardiac morbidity and mortality is important. The question is whether it is useful to screen for cardiac disease during follow up and, in case of screening, how to screen, and for exactly which cardiac disease. Radiation treatment of thoracic malignancies, for example breast cancer, can cause several types of cardiac injury, such as pericardial disease, ischemic heart disease, valvular disease, conduction system disease, autonomic changes, and cardiomyopathy ${ }^{38}$. The exact pathophysiology of radiation induced cardiovascular disease is still unclear, but one assumption is that radiation induced microvascular ischemia can lead to disruption of capillary endothelial framework, and injury to differentiated myocytes results in deposition of collagen and fibrosis. In the presence of risk factors of a metabolic syndrome and preexisting atherosclerosis, exposure of the heart to radiation results in accelerated occurrence of major coronary events ${ }^{39}$. In patients who develop coronary stenosis, the left anterior descending coronary artery (LAD) is involved in $85 \%$ of patients, and in $62 \%$ it was the sole vessel affected $^{40}$. One might assume it can be useful to be able to identify the healthy woman with a single affected coronary artery stenosis, to be able to treat them before a myocardial infarction occurs.

Investigators from MD Anderson Cancer Center made an algorithm for follow-up in irradiated patients with thoracic malignancies ${ }^{39}$. At baseline risk factors for cardiovascular disease are assessed and based on the risk stratification, follow up with echocardiogram is recommended to start 6 months after cardiotoxic chemotherapy and/or radiotherapy, to be continued during five or 10 years follow up, dependent of the risk profile. Assessment of biomarkers for cardiac damage is promising but still experimental $^{39}$.

\section{The importance of scoring toxicity for shared decision making (SDM)}

In the current society, SDM is becoming increasingly important. In the latest accreditation program of the NIAZ (Netherlands Institute for Healthcare Accreditation), Qmentum Global, which will be used from 2020, patient and family oriented care is leading in all aspects of healthcare planning, provision and evaluation ${ }^{41}$. Consequently, patients need to be informed about the aim of radiation treatment and possible side effects, when choosing between breast conserving surgery or a mastectomy. Also, in case of breast conserving surgery, patients may want to participate in the choice of whether or not receiving a boost. To help a patient with her decision, a predictive model for cosmetic outcome would be very helpful.

Besides cosmetic outcome and the above mentioned heart damage, other late side effect as secondary cancers, limited shoulder movement, pain in the breast or ribs or oedema of the breast or 
arm can occur. However, not much is known about the exact risk factors and the contribution of these individual risk factors to the final actual risk for late toxicity and prediction models are still absent. Further, when using modern radiation techniques as intensity-modulated radiotherapy (IMRT) or volumetric-modulated arc therapy (VMAT), distribution in organs at risk will be different ${ }^{42}$. Long term follow up data of these new radiation techniques are missing.

Therefore, we believe it is important to score late side effects in a structural way. This allows us to gain knowledge about the possible side effects and their severity in our own patient population. Our study showed that one can rely on PROMs for the recording of late side-effects and for identifying patients who need attention because of severe complaints ${ }^{43}$. Our institute recently started using PROMs on a regular base, enabling collection of valuable data regarding late side effects of our own patient population, which can be used in the SDM discussion with the patient.

\section{Future perspectives}

As described above, there are still many uncertainties concerning the long term effect of oncoplastic surgery on cosmetic outcome and the optimal radiotherapy planning. Various initiatives have now been taken to collect data on the result of oncoplastic surgery. For example, in the TOBO trial the Breast-Q questionnaire is used to investigate the patients' satisfaction concerning her breast after oncoplastic breast reconstruction and will be compared with the satisfaction of patients that receive a breast conserving surgery without reconstruction ${ }^{44}$.

Further, in the Netherlands, a project has started to reach national consensus on plan evaluation criteria. Four benchmark cases (breast, breast with boost, breast with axilla level I-IV and breast with axilla I-IV including internal mammary lymph nodes) have spread out among the various Dutch radiation treatment institutions to be delineated and planned. Results will be analysed and discussed to reach consensus and thereby improve dose planning at national level.

In healthcare, the number of quality indicators have been growing in the last years, with an everincreasing administrative burden as a result. Quality indicators are measurable aspects of the provision of care, which provide an indication of the degree of quality ${ }^{45}$. Further, the government, health insurance companies and patient organizations call for more transparency regarding these quality indicators. The Dutch Organization for Radiation Oncology (NVRO) has worked out a number of specific indicators for radiotherapy, including indicators regarding outcome. Examples of outcome indicators include tumor control, side effects, quality of life and patient satisfaction and scoring these items is becoming to be obligatory. The goal is that radiotherapy departments compare (benchmark) 
their score on the indicators with other radiotherapy departments. Departments that perform below average will be highly motivated to improve. Besides, the best performing departments can be asked to share their best practice with the other departments to allow the remaining departments to catch up faster ${ }^{46}$.

\section{Conclusion}

We studied several aspects of late side effects. We found that the use of a photon boost instead of an electron boost, a high boost dose (26 Gy compared to $16 \mathrm{~Gy}$ ), cosmesis at baseline, adjuvant chemotherapy and boost volume have an adverse impact om cosmetic outcome. The next step will be to develop a nomogram to estimate cosmetic outcome, to use in shared decision making on radiation treatment.

In addition, we found that our technique of $\mathrm{vmDIBH}$ is as reproducible as radiation therapy during free breathing, making it an easy and valuable tool to reduce irradiate heart volume and thereby late cardiac injury. Currently proton therapy is implemented in the Netherlands to further reduce cardiac injury in selected patients.

Finally, we showed that scoring of late side-effects by patient questionnaires is a meaningful way to record late side-effects in a structured manner. It does not only enable identifying patients who need additional care, but it will also allow to analyse data at a group level, e.g. to analyse time-trends within the institute and differences between institutes 


\section{References}

1. Van Der Waal D, Verbeek ALM, Den Heeten GJ, Ripping TM, Tjan-Heijnen VCG, Broeders MJM. Breast cancer diagnosis and death in the Netherlands: A changing burden. Eur J Public Health. 2015;25(2):320-324. doi:10.1093/eurpub/cku088.

2. https://www.cijfersoverkanker.nl/. https://www.cijfersoverkanker.nl/.

3. Bartelink $\mathrm{H}$, Maingon $\mathrm{P}$, Poortmans $\mathrm{P}$, et al. Whole-breast irradiation with or without a boost for patients treated with breast-conserving surgery for early breast cancer : 20-year follow-up of a randomised phase 3 trial. Lancet Oncol. 2015;16:47-56. doi:10.1016/S14702045(14)71156-8.

4. Immink JM, Putter $\mathrm{H}$, Bartelink $\mathrm{H}$, et al. Long-term cosmetic changes after breast-conserving treatment of patients with stage I-II breast cancer and included in the EORTC "boost versus no boost" trial. Ann Oncol. 2012;23(10):2591-2598. doi:10.1093/annonc/mds066.

5. Brouwers PJAM, van Werkhoven $\mathrm{E}$, Bartelink $\mathrm{H}$, et al. Predictors for poor cosmetic outcome in patients with early stage breast cancer treated with breast conserving therapy: Results of the Young boost trial. Radiother Oncol. 2018;128(3):434-441. doi:10.1016/j.radonc.2018.06.020.

6. Brouwers PJAM, van Werkhoven E, Bartelink $\mathrm{H}$, et al. Factors associated with patientreported cosmetic outcome in the Young Boost Breast Trial. Radiother Oncol. 2016;120(1):107-113. doi:10.1016/j.radonc.2016.04.017.

7. Barnett GC, Wilkinson JS, Moody a M, et al. The Cambridge Breast Intensity-modulated Radiotherapy Trial: patient- and treatment-related factors that influence late toxicity. Clin Oncol (R Coll Radiol). 2011;23(10):662-673. doi:10.1016/j.clon.2011.04.011.

8. Mukesh MB, Barnett GC, Wilkinson JS, et al. Randomized controlled trial of intensitymodulated radiotherapy for early breast cancer: 5 -year results confirm superior overall cosmesis. J Clin Oncol. 2013;31(36):4488-4495. doi:10.1200/JCO.2013.49.7842.

9. Peterson D, Truong PT, Parpia S, et al. Predictors of Adverse Cosmetic Outcome in the RAPID Trial: An Exploratory Analysis. Int J Radiat Oncol. 2015;91(5):968-976. doi:10.1016/j.ijrobp.2014.12.040.

10. Veldeman L, Schiettecatte K, De Sutter C, et al. The 2-year cosmetic outcome of a randomized trial comparing prone and supine whole-breast irradiation in large-breasted women. Int J Radiat Oncol Biol Phys. 2016;95(4):1210-1217. doi:10.1016/j.ijrobp.2016.03.003.

11. Haviland JS, Owen JR, Dewar J a., et al. The UK Standardisation of Breast Radiotherapy (START) trials of radiotherapy hypofractionation for treatment of early breast cancer: 10-year follow-up results of two randomised controlled trials. Lancet Oncol. 2013;14(11):1086-1094. doi:10.1016/S1470-2045(13)70386-3.

12. Whelan TJ, Pignol J-P, Levine MN, et al. Long-term results of hypofractionated radiation therapy for breast cancer. N Engl J Med. 2010;362(6):513-520. doi:10.1056/NEJMoa0906260.

13. Mukesh MB, Harris E, Collette $\mathrm{S}$, et al. Normal tissue complication probability (NTCP) parameters for breast fibrosis: pooled results from two randomised trials. Radiother Oncol. 2013;108(2):293-298. doi:10.1016/j.radonc.2013.07.006.

14. Collette $\mathrm{S}$, Collette $\mathrm{L}$, Budiharto $\mathrm{T}$, et al. Predictors of the risk of fibrosis at 10 years after breast conserving therapy for early breast cancer: a study based on the EORTC Trial 2288110882 "boost versus no boost". Eur J Cancer. 2008;44(17):2587-2599. doi:10.1016/j.ejca.2008.07.032. 
15. Hammer C, Maduro JH, Bantema-Joppe EJ, et al. Radiation-induced fibrosis in the boost area after three-dimensional conformal radiotherapy with a simultaneous integrated boost technique for early-stage breast cancer: A multivariable prediction model. Radiother Oncol. 2017;122(1):45-49. doi:10.1016/j.radonc.2016.10.006.

16. Vrieling C, Collette L, Fourquet A, et al. The Influence of the Boost in Breast-conserving Therapy on Cosmetic Outcome in the EORTC "Boost versus no Boost " Trial. Int J Radiat Oncol. 1999;45(3):677-685.

17. Immink JM, Putter $\mathrm{H}$, Bartelink $\mathrm{H}$, et al. Long-term cosmetic changes after breast-conserving treatment of patients with stage I-II breast cancer and included in the EORTC "boost versus no boost" trial. Ann Oncol. 2012;23(10):2591-2598. doi:10.1093/annonc/mds066.

18. Bantema-Joppe EJ, Schilstra C, de Bock GH, et al. Simultaneous integrated boost irradiation after breast-conserving surgery: physician-rated toxicity and cosmetic outcome at 30 months' follow-up. Int J Radiat Oncol Biol Phys. 2012;83(4):e471-7. doi:10.1016/j.ijrobp.2012.01.050.

19. Lansu JTP, Essers M, Voogd AC, et al. The influence of simultaneous integrated boost, hypofractionation and oncoplastic surgery on cosmetic outcome and PROMs after breast conserving therapy. Eur J Surg Oncol. 2015;41(10):1411-1416. doi:10.1016/j.ejso.2015.07.011.

20. Campbel EJ, Romics L. Oncological safety and cosmetic outcomes in oncoplastic breast conservation surgery, a review of the best level of evidence literature. Breast Cancer Targets Ther. 2017;9:521-530. doi:10.2147/BCTT.S113742.

21. Macmillan RD, McCulley SJ. Oncoplastic Breast Surgery: What, When and for Whom? Curr Breast Cancer Rep. 2016;8(2):112-117. doi:10.1007/s12609-016-0212-9.

22. Haloua MH, Krekel NMA, Jacobs GJA, et al. Cosmetic Outcome Assessment following BreastConserving Therapy: A Comparison between BCCT.core Software and Panel Evaluation. Int J Breast Cancer. 2014;2014:1-7. doi:10.1155/2014/716860.

23. https://www.volksgezondheidenzorg.info/onderwerp/hart-en-vaatziekten/cijferscontext/huidige-situatie\#node-prevalentie-hart-en-vaatziekten-huisartsenpraktijk-naarleeftijd-en-geslacht.

24. Cheng YJ, Nie XY, Ji CC, et al. Long-term cardiovascular risk after radiotherapy in women with breast cancer. J Am Heart Assoc. 2017;6(5). doi:10.1161/JAHA.117.005633.

25. Darby SC, Ewertz M, McGale P, et al. Risk of ischemic heart disease in women after radiotherapy for breast cancer. N Engl J Med. 2013;368(11):987-998. doi:10.1056/NEJMoa1209825.

26. Brouwers PJAM, Lustberg T, Borger JH, et al. Set-up verification and 2-dimensional electronic portal imaging device dosimetry during breath hold compared with free breathing in breast cancer radiation therapy. Pract Radiat Oncol. 2015;5(3):e135-e141. doi:10.1016/j.prro.2014.10.005.

27. Bartlett FR, Colgan RM, Donovan EM, et al. Voluntary Breath-hold Technique for Reducing Heart Dose in Left Breast Radiotherapy. J Vis Exp. 2014;(89):1-9. doi:10.3791/51578.

28. Bartlett FR, Colgan RM, Carr K, et al. The UK HeartSpare Study: Randomised evaluation of voluntary deep-inspiratory breath-hold in women undergoing breast radiotherapy. Radiother Oncol. 2013;108(2):242-247. doi:10.1016/j.radonc.2013.04.021.

29. https://www.varian.com/oncology/products/real-time-tracking-motion-management/real- 
time-position-management-rpm. https://www.varian.com/oncology/products/real-timetracking-motion-management/real-time-position-management-rpm.

30. Mast ME, Vredeveld EJ, Credoe HM, et al. Whole breast proton irradiation for maximal reduction of heart dose in breast cancer patients. Breast Cancer Res Treat. 2014;148(1):3339. doi:10.1007/s10549-014-3149-6.

31. MacDonald SM, Patel SA, Hickey S, et al. Proton therapy for breast cancer after mastectomy: Early outcomes of a prospective clinical trial. Int J Radiat Oncol Biol Phys. 2013;86(3):484-490. doi:10.1016/j.ijrobp.2013.01.038.

32. Jacob S, Camilleri J, Derreumaux $S$, et al. Is mean heart dose a relevant surrogate parameter of left ventricle and coronary arteries exposure during breast cancer radiotherapy: $A$ dosimetric evaluation based on individually-determined radiation dose (BACCARAT study). Radiat Oncol. 2019;14(1):1-10. doi:10.1186/s13014-019-1234-z.

33. Kanker oorzaak bij 31 procent van de sterfgevallen. https://www.cbs.nl/nl$\mathrm{nl} /$ nieuws/2018/28/kanker-oorzaak-bij-31-procent-van-de-sterfgevallen.

34. Gernaat SAM, Ho PJ, Rijnberg N, et al. Risk of death from cardiovascular disease following breast cancer: a systematic review. Breast Cancer Res Treat. 2017;164(3):537-555. doi:10.1007/s10549-017-4282-9.

35. Vejpongsa P, Yeh ETH. Prevention of anthracycline-induced cardiotoxicity: Challenges and opportunities. J Am Coll Cardiol. 2014;64(9):938-945. doi:10.1016/j.jacc.2014.06.1167.

36. Guenancia C, Lefebvre A, Cardinale D, et al. Obesity as a risk factor for anthracyclines and trastuzumab cardiotoxicity in breast cancer: A systematic review and meta-analysis. J Clin Oncol. 2016;34(26):3157-3165. doi:10.1200/JCO.2016.67.4846.

37. Johnson CB, Davis MK, Law A, Sulpher J. Shared Risk Factors for Cardiovascular Disease and Cancer: Implications for Preventive Health and Clinical Care in Oncology Patients. Can J Cardiol. 2016;32(7):900-907. doi:10.1016/j.cjca.2016.04.008.

38. Nielsen KM, Offersen BV, Nielsen HM, Vaage-Nilsen M, Yusuf SW. Short and long term radiation induced cardiovascular disease in patients with cancer. Clin Cardiol. 2017;40(4):255261. doi:10.1002/clc.22634.

39. Yusuf SW, Venkatesulu BP, Mahadevan LS, Krishnan S. Radiation-Induced Cardiovascular Disease: A Clinical Perspective. Front Cardiovasc Med. 2017;4(October):1-7. doi:10.3389/fcvm.2017.00066.

40. Correa CR, Litt HI, Hwang WT, Ferrari VA, Solin L, Harris EE. Coronary artery findings after left-sided compared with right-sided radiation treatment for early-stage breast cancer. J Clin Oncol. 2007;25(21):3031-3037. doi:10.1200/JCO.2006.08.6595.

41. NIAZ. https://www.niaz.nl/english.

42. Jeulink M, Dahele M, Meijnen P, Slotman BJ, Verbakel WFAR. Is there a preferred IMRT technique for left-breast irradiation? J Appl Clin Med Phys. 2015;16(3):197-205. doi:10.1120/jacmp.v16i3.5266.

43. Brouwers PJAM, van Loon J, Houben RMA, et al. Are PROMs sufficient to record late outcome of breast cancer patients treated with radiotherapy? A comparison between patient and clinician reported outcome through an outpatient clinic after 10 years of follow up. Radiother Oncol. 2018;126(1):163-169. doi:10.1016/j.radonc.2017.08.004.

44. https://www.trialregister.nl/. https://www.trialregister.nl/. 
45. Normeringsrapport S. M U LT I D I S C I P L I N A I R E ZORG IN NEDERLAND. 2019.

46. Nvro CK. Visie indicatoren binnen de radiotherapie. 2018:1-7. 
Chapter 7

Summary 


\section{Summary}

\section{Breast cancer}

Chapter 1 provides an introduction to the treatment of early stage breast cancer and the side effects of radiation therapy, resulting in the questions in this thesis. Breast cancer is the most common cancer in women and the risk of being diagnosed with invasive breast cancer has increased over the past decades: in the Netherlands, one of seven women will be diagnosed with invasive breast cancer at one point in her life. At the same time, breast cancer treatment has improved significantly, almost $80 \%$ of all women diagnosed with breast cancer survives for at least 10 years. Consequently, there is an increasing group of long-time survivors. Given the good prognosis of (especially early discovered) breast cancer, there is growing attention for limiting the side effects of treatment, and thereby improving quality of life as much as possible, whilst maintaining the good oncological outcome. Apart from surgery and systemic treatment, radiotherapy plays a major role in the treatment of breast cancer. In patients with early breast cancer, breast conserving therapy, i.e. lumpectomy followed by breast irradiation, is nowadays considered as standard of care. Optionally, chemotherapy or hormone therapy can be added. Adjuvant radiotherapy shows a relative reduction in loco-regional recurrences of $60-70 \%$ in patients treated with breast conserving surgery. If indicated, an additional dose can be given to the original tumour area (the boost). An additional boost to the tumour bed reduces the risk for local failure even further by a factor of 2 . By combining surgery with radiation during breastconserving treatment, this treatment is at least as safe as the standard mastectomy performed decades ago, but with the advantage that women can retain their breasts.

\section{Side effects}

Unfortunately, every anti-cancer treatment also has side effects. In the case of radiation, healthy cells can also be damaged. In case of breast conserving therapy, the breast radiation follows after surgery. Basically, no visible cancer cells are present anymore, the radiation therapy is a preventive treatment to eliminate any microscopic cancer cells and thereby prevent the disease from recur at a later stage. Because the exact location of these invisible cancer cell is unknown, we irradiate the whole breast (or partial) with or without a boost and whether or not supplemented with elective regional nodal areas. Any late side effects that could occur as a result of the radiation are reduced shoulder function, fluid retention in the arms (lymphedema, in case of irradiation of the armpit glands) and fibrosis (scarring / hardening) of the breast. The risk of fibrosis and the severity of this fibrosis enlarges with increasing radiation dose. Because breast irradiation is administered with tangential fields, there is also a small risk of damage to the lungs and in the case of left-sided breast cancer, to the heart. 
The central theme of these thesis was to get insight in several aspects of some late side effects:

- To predict cosmetic outcome, not only to have clues how to improve cosmetic outcome, but also to use in shared decision making when choosing on radiation treatment. For this purpose, we used the data of the Young Boost Trial (YBT). In this trial the effect of a higher boost dose on local recurrence and cosmetic outcome was investigated in patients $\leq 50$ years of age. We analysed the cosmetic outcome of the Young Boost Trial.

- To prevent late side-effects, i.e. cardiac injury, by investigating whether our technique of Voluntary moderately Deep Inspiration Breath Hold ( $\mathrm{vmDIBH}$ ) is actually reproducible.

- To record all late-side effects in a structured way:

$\bigcirc$ to identify patients needing additional care

○ to enable development of prognostic models

○ to be able to compare outcome data with other radiation therapy centres or with historic controls.

Consequently, the three main aims of this thesis were:

1. To determine which factors are important for:

a. patient reported cosmetic outcome

b. fibrosis (scored by physician)

c. cosmetic outcome (based on BCCT.core)

To determine these factors, we analysed which risk factors were associated with a worse cosmetic outcome in the YBT trial, based on the objective BCCT.core score. Further, we reported on the amount of moderate/severe fibrosis and defined the risk factors for moderate/severe fibrosis in the boost area (Chapters 2 \& 3).

2. To investigate/develop an easy but reproducible and affordable breath hold manoeuvre to reduce the dose to the heart (Voluntary moderately Deep Inspiration Breath Hold, vmDIBH).

Chapter 4 reports on the careful step-by-step introduction of voluntary moderately deep inspiration breath hold (vmDIBH) in our institute.

3. To investigate whether patient reported outcome measures (PROMS) are sufficiently reliable to record late outcome (Chapter 5). 


\section{Cosmetic outcome and fibrosis}

The EORTC " boost versus no boost " study had previously shown that the risk of a local recurrence can be reduced further by adding a boost to the whole breast irradiation, compared to irradiation of the whole breast alone. However, this study also showed that the younger patients still remained at a risk of a local failure of $13.5 \%$ percent at ten years. Because this was considered as an unacceptable high risk, a new study was designed, the so-called Young Boost Trial (YBT). In this study patients of 50 years and younger with early breast cancer were randomized between a standard boost dose or a high boost dose in addition to whole breast irradiation. The results regarding the influence on the boost dose on the risk of a local recurrence are not yet sufficiently mature for analysis, but preliminarily results of both arms together show that the risk of a local recurrence is much lower than previously estimated (about $2.2 \%$ at 4 years).

In chapters $\mathbf{2}$ and $\mathbf{3}$ of this thesis we used data from the YBT to analyse cosmetic outcome at 4 years of follow up. Defining cosmetic outcome is often considered as controversial, because of its subjective nature. After all, who decides what is "beautiful"? To score cosmetic outcome as objectively as possible, we have used the BCCT.core program. This is a software program with which digital photographs, can be analysed, resulting in an objective score for the overall cosmetic outcome: excellent, good, fair or poor. This score is based on symmetry (7 features), skin colour and scar visibility.

Although an objective measure for cosmetic outcome is obviously important, especially in the context of studies, or to be able to detect changes over time, patients' satisfaction regarding her own breast is also essential. In chapter $\mathbf{2}$ we investigated which symmetry features are most important for patients to be satisfied with the appearance of her breast. Our analysis showed that the distance between the nipple and the inframammary fold (the lower edge of the breast), the length of the breast contour and the severity of fibrosis are the most determining factors for patient satisfaction.

In chapter 3 we investigated which treatment-related factors influence cosmetic outcome, based on the objective BCCT.core. It turned out that a higher boost dose compared to the standard boost dose, a photon boost instead of an electron boost, poor cosmesis before start radiation treatment (baseline cosmesis), a large boost volume and adjuvant chemotherapy were defined as risk factors for worse cosmetic outcome. 


\section{Prevention of cardiac toxicity}

Breast or thoracic wall irradiation is generally largely given using tangential fields. In case of left-sided breast cancer, the heart can be partially located within the radiation field. It is known that dose to the heart can lead to heart damage, whereby the higher the dose in the heart, the higher the risk of heart disease during follow up. Therefore, it is important to keep the dose in the heart as low as possible. Multiple respiratory techniques have been described to spare the heart. All techniques are based on the principle that during deep inspiration the heart moves out of the radiation field. A simple and inexpensive method is based on a voluntary breath hold. However, since the breath hold is voluntary, it is difficult to properly control this breath hold and therefore the reproducibility of this method is questioned.

In chapter 4 we report on the step-by-step implementation of this voluntary moderate deep inspiration breath hold ( $\mathrm{vmDIBH}$ ) in Maastro and how we have simplified the technique during the implementation process. Initially, patients received 3 CT scans in 2 days. On day 1, two CT-scans were obtained; one in both free breathing and one breath hold scan. If the breath hold scan showed that the heart had been properly moved backwards, a new breath hold scan was obtained 2 days later, after the patient had practicing breath hold at home. The depth of inhalation was checked with the "breathing stick". This breathing stick was a ruler that was placed vertically on the skin of the epigastric area (just outside the irradiated area) at a marked point. The depth of the breath hold could be determined by reading this ruler. During treatment, the radiation technician could check visually, and the patient could

feel, whether the tip of the stick made contact at the marked dot on the skin, ensuring a correct breath hold. Subsequently, this entire process was simplified to only the 2 CT scans on day 1 , the trained scan was not necessary. Also, the breath hold appeared to be very reproducibly without using the breathing stick; the use of the breathing stick could therefore be omitted. In order to be able to simplify this technique step by step in a controlled way, we investigated the reproducibility in each step. We have analysed both the regular set-up photos and the results of epidosimetry. In epidosimetry, the dose is measured after the patient and compared with the expected dose, based on the initial treatment planning. In case of incorrect reproducibility, i.e. different position of the patient or deviant breath hold, you would measure an incorrect dose behind the patient. The results showed that, although there was quite some variation, both the geographical set-up and the measured dose in patients with vmDIBH did not differ significantly from patients who were irradiated during free breathing. 


\section{Follow up}

Patients are often treated by several medical specialists (surgeon, oncologist, radiation oncologist). It is impossible and undesirable, to visit the outpatient clinic of each doctor for several years, both because of the expanding outpatient clinic as of the time it will cost the patient. However, it is important for the doctor to obtain information concerning the late side effects or complications (toxicity), both to learn about the effects of their treatment, but also because of a social demand to make treatment effects transparent. In addition, the patient should be offered additional care if she or he suffers from late side effects. To investigate whether we would receive adequate information from patients by asking them to complete questionnaires about the toxicity, we established the outpatient clinic for late effects in breast cancer (OCLO) (chapter 5). We asked patients who were irradiated for breast cancer 10 years ago to complete a comprehensive questionnaire about side effects and the quality of life. They were also asked to visit the outpatient clinic once in order to compare their answers with the doctors' findings.

Half of the patients ( $n=341$ ) were willing to fill in the questionnaires, 249 patients were willing to visit the outpatient clinic. We found that, at a group level, patients scored their toxicity a little higher than the doctor at the outpatient clinic reported. Consequently, we concluded that by using questionnaires to determine toxicity of the treatment, toxicity will certainly not be underestimated. It also turned out that the questionnaires can be used for identifying patients who need additional attention because of severe complaints; they can be asked to visit the outpatient clinic to look for solutions. We have therefore concluded that it is possible to rely on questionnaires the recording of late side-effects.

\section{Discussion and future perspectives}

In chapter 6 the results are discussed and some important (future) projects are mentioned.

The ultimate goal is to use the results of the Young Boost Trial to make a prediction model for cosmetic outcome that can be used in the medical office. The patient and doctor can decide together on the intensity of the radiation (for example, whether or not to boost), whereby the patient can be well informed about the benefits (less chance of disease recurrence) and disadvantages (risk of side effects, for example worse cosmetic outcome).

An important relatively new development is the oncoplastic surgery. An increasing number of patients is undergoing oncoplastic surgery. In oncoplastic surgery, the lumpectomy cavity is closed and the contour of the breast is restored by translation and / or rotation the remaining breast tissue. Obviously, the aim of oncoplastic surgery is a better cosmetic result. However, it could be that after oncoplastic surgery (more wounds in the breast as a result of displacement, perhaps more seroma), more fibrosis occurs as a result of the radiation therapy. Unfortunately, no long term cosmetic results 
of oncoplastic surgery are available. To obtain more information about late side effects, it is important to record them in a structured way.

Although we know more and more about risk factors concerning late side effects, there are still many uncertainties. Consequently, no consensus exists regarding optimal radiation treatment planning. For instance, is it more important to spare the heart as much as possible, resulting in underdosage at the medial side of the breast, or, in the case of a boost, a larger area in the breast receiving a higher dose, resulting in a worse cosmetic outcome? In the Netherlands, a project has been started to harmonize plan evaluation, with the aim of achieving national consensus.

To spare the heart during the radiation treatment, various, more or less invasive methods are available, all based on the fact that a breath hold moves the heart out of the radiation field. In the Netherlands, proton therapy became just recently available. With proton therapy it is possible to irradiate the target volume very precise and save surrounding tissues (such as the heart). Patients with breast cancer are only eligible for this treatment in The Netherlands, when a clinically relevant reduction in the risk of late heart damage can be achieved with proton therapy. For now, this clinically relevant reduction of hearts injury is estimated based om a prognostic model. To demonstrate the benefit of proton therapy, it is important to record late toxicity. In the long term, for example, data can be used to demonstrate that proton therapy does indeed reduce the risk of heart damage. Therefore, there are several arguments for obtaining good follow-up data. In this thesis we made a proposal about how this could be possible (Chapter 5).

\section{Conclusion:}

We studied several aspects of late side effects. We found that the use of a photon boost instead of an electron boost, a high boost dose, cosmesis at baseline, adjuvant chemotherapy and boost volume have an adverse impact om cosmetic outcome. The next step will be to develop a nomogram to estimate cosmetic outcome, to use in shared decision making on radiation treatment.

In addition, we found that our technique of $\mathrm{vmDIBH}$ is as reproducible as radiation therapy during free breathing, making it an easy and valuable tool to reduce irradiate heart volume and thereby late cardiac injury. Currently proton therapy is implemented in the Netherlands to further reduce cardiac injury in selected patients.

Finally, we showed that scoring of late side-effects by patient questionnaires is a meaningful way to record late side-effects in a structured manner. It does not only enable identifying patients who need additional care, but it will also allow to analyse data at a group level, e.g. to analyse time-trends within the institute and differences between institutes. 


\section{Nederlandse samenvatting}

\section{Borstkanker}

In hoofdstuk 1 is een inleiding gegeven op de behandeling van relatief vroeg stadium borstkanker en de bijwerkingen van bestraling, resulterend in de vraagstellingen in deze thesis. Borstkanker is de meest voorkomende vorm van kanker bij vrouwen en het risico om borstkanker te krijgen is toegenomen in de afgelopen decennia. Inmiddels zal bij 1 op de 7 Nederlandse vrouwen ergens in haar leven de diagnose borstkanker gesteld worden. Tegelijkertijd is de behandeling van borstkanker sterk verbeterd, bijna $80 \%$ van alle vrouwen met de diagnose borstkanker leeft minimaal 10 jaar. Er is dus een toenemende groep vrouwen die borstkanker overleven en daarna lang(er) doorleven. Gezien de goede prognose van (met name vroeg ontdekte) borstkanker, is er steeds meer aandacht gekomen voor de late bijwerkingen van de behandeling van borstkanker. De focus is verlegd van verbeteren van de overleving naar verbeteren van de kwaliteit van leven, zonder dat de overleving daarbij slechter wordt.

Naast operatieve behandeling en systemische behandeling (hormoontherapie en/of chemotherapie) worden veel patiënten met borstkanker ook bestraald. De borstsparende behandeling bestaat uit een operatie waarbij de tumor wordt verwijderd (lumpectomie), gevolgd door bestraling van de borst. Eventueel kan er nog chemotherapie of hormoontherapie toegevoegd worden. De aanvullende bestraling zorgt ervoor dat de kans op terugkeer van de ziekte in de borst met $60-70 \%$ verlaagd wordt. Indien geïndiceerd kan nog een extra dosis op het oorspronkelijke tumorgebied gegeven worden (de boost), dit zal het risico op terugkeer van de ziekte nog eens met een factor 2 verkleinen. Door bij een borstsparende behandeling een operatie te combineren met bestraling, is deze behandeling minstens net zo veilig als de borstamputaties die decennia geleden standaard verricht werden, echter met als voordeel dat vrouwen hun borst kunnen behouden.

\section{Bijwerkingen}

Helaas heeft iedere antikankerbehandeling ook bijwerkingen. In geval van bestraling worden ook gezonde cellen beschadigd door de bestraling. Bij de behandeling van borstkanker volgt de bestraling na de operatie. Er zijn dan in principe geen zichtbare kankercellen meer, de bestraling is een preventieve behandeling om eventuele niet zichtbare kankercellen uit te schakelen en daardoor te voorkomen dat de ziekte in een later stadium weer terug kan komen. Omdat we niet goed weten waar de niet zichtbare kankercel zich bevindt, bestralen we de hele borst (of een deel) al dan niet aangevuld met een boost op de plaats waar de tumor oorspronkelijk gezeten heeft en al dan niet aangevuld met de regio waar de okselklieren zich bevinden. Eventuele late bijwerkingen die door de bestraling 
zouden kunnen ontstaan, zijn een verminderde schouderfunctie, vochtophoping in de armen (lymfoedeem, in geval van bestraling van de okselklieren) en fibrose (verlittekening / verharding) van de borst. De kans op fibrose en de ernst van deze fibrose is groter bij een hogere bestralingsdosis. Omdat de borstbestraling met schampende velden toegediend wordt, is er ook klein risico op schade aan de longen en in geval van linkszijdige borstkanker, aan het hart.

Het centrale thema van dit proefschrift was om inzicht te krijgen in verschillende aspecten van enkele late bijwerkingen:

- Om cosmetische uitkomst te voorspellen, niet alleen om aanwijzingen te hebben over hoe de cosmetische uitkomst te verbeteren, maar ook om te gebruiken bij gedeelde besluitvorming bij de keuze voor een bestralingsbehandeling. Voor dit doel hebben we de gegevens van de Young Boost Trial (YBT) gebruikt. In deze studie werd het effect van een hogere boostdosis op het risico op een lokaal recidief en het cosmetische resultaat onderzocht bij patiënten $\leq 50$ jaar oud. We hebben de cosmetische uitkomst van de Young Boost Trial geanalyseerd.

- Om late bijwerkingen (hartschade) te voorkomen door te onderzoeken of onze techniek (Voluntary moderately Deep Inspiration Breath Hold (vmDIBH)) van breath hold (bestralen met ingehouden adem) daadwerkelijk reproduceerbaar is.

- Om alle late bijwerkingen op een gestructureerde manier te registreren:

- om patiënten te identificeren die extra zorg nodig hebben

- om de ontwikkeling van prognostische modellen mogelijk te maken

- om uitkomstgegevens te kunnen vergelijken met andere radiotherapiecentra of met historische controles

De drie doelstellingen van dit proefschrift waren daarmee:

1. Bepalen welke factoren van invloed zijn op:

a) Door de patiënte gerapporteerde cosmetiek

b) Fibrose (gescoord door de arts)

c) Cosmetiek (op basis van een softwareprogramma (BCCT.core))

Om deze factoren te kunnen bepalen, hebben we geanalyseerd welke factoren geassocieerd zijn met een slechtere cosmetiek in de YBT. Daarnaast hebben we ook beschreven hoe vaak er matig tot ernstige fibrose werd gevonden en hebben we gekeken wat de risicofactoren waren voor matig tot ernstige fibrose (Hoofdstuk 2 \& 3). 
2. Onderzoeken en ontwikkelen van een gemakkelijke en reproduceerbare breath hold methode (bestralen met ingehouden adem) om zo de dosis in het hart zo laag mogelijk te krijgen (Voluntary moderately Deep Inspiration Breath Hold, vmDIBH).

In hoofdstuk 4 beschrijven we hoe we deze vmDIBH stap voor stap hebben geïntroduceerd in ons instituut.

3. Onderzoeken of vragenlijsten verstuurd aan patiënten betrouwbare informatie opleveren over late bijwerkingen (Hoofdstuk 5).

\section{Cosmetiek en fibrose}

De EORTC "boost versus no boost" studie had eerder al laten zien dat het risico op een lokaal recidief (het plaatselijk terugkeren van ziekte in de borst) verder verlaagd kan worden door het toevoegen van een boost aan de bestraling van de gehele borst, vergeleken met bestraling van de gehele borst alleen. In deze studie bleek echter dat het risico op terugkeer van de ziekte in de borst, ondanks het toevoegen van de boost, bij de jongere vrouwen nog steeds meer dan ruim $13 \%$ na 10 jaar was. Omdat dit als een te hoog risico werd beschouwd, werd in 2003 een nieuwe studie opgezet, de zogenaamde Young Boost Trial (YBT). In deze studie werden vrouwen van 50 jaar oud of jonger, met vroege, beperkte borstkanker geïncludeerd die een borstsparende operatie hadden ondergaan. Vervolgens werd er voor de bestralingsbehandeling geloot tussen een standaard boost dosis en een extra hoge boost dosis, in aanvulling op de standaard bestraling op de gehele borst. De resultaten wat betreft de invloed op de boost dosis op het risico van een lokaal recidief zijn nog niet gepubliceerd, maar de recidiefkans voor de totale studiepopulatie is veel lager dan tevoren was ingeschat (ongeveer $2.2 \%$ na 8 jaar).

In hoofdstuk 2 en 3 van dit proefschrift hebben we gegevens van de YBT gebruikt om de cosmetische uitkomst tot 4 jaar na de bestraling te analyseren. Cosmetiek is ontzettend moeilijk om te scoren, omdat het een hele subjectieve maat is. Wie bepaalt immers wat 'mooi' is? Om cosmetiek toch zo objectief mogelijk te kunnen scoren hebben we gebruik gemaakt van het BCCT.core programma. Dit is een softwareprogramma dat aan de hand van digitale foto's van de borsten een score geeft. Foto's worden beoordeeld op symmetrie (op basis van 7 symmetrie kenmerken) tussen beide borsten, de kleur van de huid en de zichtbaarheid van het litteken. BCCT.core geeft dan een score betreffende de cosmetiek: slecht, matig, goed of uitstekend.

Hoewel een objectieve maat voor cosmetiek natuurlijk heel belangrijk is, vooral in studieverband of om verandering in de loop van de tijd goed te kunnen vervolgen, is de tevredenheid van de patiënte betreffende haar eigen borst ook van wezenlijk belang. In hoofdstuk 2 hebben we onderzocht welke 
symmetrie kenmerken voor patiënten het belangrijkst zijn om tevreden te zijn met het uiterlijk van de borst. Uit onze analyse bleek dat de afstand tussen de tepel en de inframammair plooi (de onderrand van de borst), de lengte van de borstcontour en de mate van fibrose het meest bepalend te zijn voor patiënttevredenheid.

In hoofdstuk 3 hebben we onderzocht welke behandeling-gerelateerde factoren invloed hebben op de cosmetiek, gemeten met de objectieve BCCT.core. Het bleek dat een hogere boost dosis in vergelijking met de standaard boost dosis, een fotonen boost in plaats van een elektronen boost, een al minder fraaie cosmetiek vóór start van de bestralingsbehandeling, een groter volume van de borst wat de boost dosis krijgt en het ondergaan van aanvullende chemotherapie, risicofactoren zijn om een minder fraaie borst te ontwikkelen in de follow up.

\section{Voorkómen van hartschade}

Bij bestraling van de borst of borstwand wordt over het algemeen het grootste deel van de dosis gegeven middels schampvelden. Bij linkszijdige borstkanker is het dan mogelijk dat het hart voor een deel in het bestralingsveld ligt. Het is bekend dat dosis in het hart kan leiden tot schade aan het hart, waarbij geldt dat hoe meer dosis in het hart, hoe groter de kans op hartklachten op termijn. Het is dus van belang om de dosis in het hart zo laag mogelijk te houden.

Er zijn meerdere ademhalingstechnieken beschreven om het hart te sparen. Al deze technieken hebben als gemeenschappelijke deler dat bij een diepe inademing het hart verplaatst in de borstkas en weg beweegt van de borstwand. Een simpele en goedkope methode is op basis van een zogenaamde vrijwillige inademing. Echter, bij deze methode is het moeilijk om de inademing goed te controleren en daarom wordt getwijfeld aan de reproduceerbaarheid van deze methode.

In hoofdstuk 4 beschrijven we stap voor stap hoe we deze voluntary moderate deep inspiration breath hold (vmDIBH) in Maastro hebben geïmplementeerd, en hoe we de techniek gedurende het implementatieproces vereenvoudigd hebben. Aanvankelijk kregen patiënten 3 CT-scans in 2 dagen, waarbij op dag 1 een CT-scan werd gemaakt in zowel vrije ademhaling als een scan met ingehouden adem. Indien op de CT-scan te zien was dat het hart op de scan met ingehouden adem goed naar achteren verplaatst was, werd 2 dagen later een nieuwe scan met ingehouden adem gemaakt, nadat patiënte thuis wat ademoefeningen had gedaan. De diepte van inademing werd gecontroleerd met het 'ademstokje'. Dit ademstokje was een meetlat, die verticaal op de huid van de maagregio (net buiten het bestraalde gebied) geplaatst werd op een gemarkeerd punt. Door deze meetlat af te lezen, kon bepaald worden hoe diep de patiënte had ingeademd. Bij iedere bestraling kon dan gecontroleerd worden of patiënte even diep in had geademd. Vervolgens is dit hele proces vereenvoudigd naar alleen de 2 CT-scans op dag 1, een geoefende scan bleek niet nodig. Ook bleken patiënten heel 
reproduceerbaar in te ademen zonder gebruik van het ademstokje; het gebruik van het ademstokje kon dus afgeschaft worden. Om deze techniek stap voor stap gecontroleerd te kunnen vereenvoudigen, hebben we in iedere stap de reproduceerbaarheid onderzocht. Hiervoor hebben we zowel de reguliere set-up foto's als resultaten van de epidosimetrie geanalyseerd. Bij epidosimetrie wordt de dosis achter de patiënte gemeten en vergeleken met wat we verwachtten te meten op basis van de initiële dosisberekeningen. Als de reproduceerbaarheid niet goed zou zijn en een patiënte telkens anders zou liggen en anders zou inademen zou je een andere dosis meten achter de patiënte. De resultaten lieten zien dat, ondanks dat er best wat variatie was, zowel de geografische set-up als de gemeten dosis bij patiënten met vmDIBH niet significant verschilden van patiënten die met de standaard vrije ademhaling bestraald werden.

\section{Follow up}

Patiënten worden vaak behandeld door meerdere specialisten (chirurg, oncoloog, radiotherapeut). Het is ondoenlijk en onwenselijk om bij alle artsen meerdere jaren op controle te blijven komen, zowel vanwege het uitpuilende spreekuur van de arts als vanwege de tijdinvestering die dat van de patiënte vraagt. Het is echter belangrijk voor de specialist om toch informatie te krijgen over de late bijwerkingen of complicaties (toxiciteit) die een patiënte ondervindt, zowel om te leren over de effecten van je behandeling, als ook omdat er een maatschappelijke vraag is om de behandeleffecten transparant te maken. Bovendien moet de patiënt extra zorg worden geboden als zij of hij last heeft van late bijwerkingen. Om te onderzoeken of we, door patiënten vragenlijsten in te laten vullen over de toxiciteit die ze ervaren, adequate informatie zouden krijgen, hebben we de polikliniek voor late effecten bij het mammacarcinoom (borstkanker) (PLEM) opgericht (hoofdstuk 5). We hebben patiënten die 10 jaar eerder bestraald waren voor borstkanker gevraagd om een uitgebreide vragenlijst in te vullen over bijwerkingen die zij ervaren en de kwaliteit van leven. Ook werd hen gevraagd om eenmalig op de polikliniek te komen zodat we de rapportage van de artsen konden vergelijken met die van patiënten.

De helft van de patiënten $(n=341)$ die we aangeschreven hebben, was bereid de vragenlijsten in te vullen, 249 patiënten waren bereid om ook op de polikliniek te komen. Het bleek dat op groepsniveau patiënten hun bijwerkingen iets ernstiger scoorden dan de arts op de poli dat deed. Door de vragenlijsten te gebruiken om de toxiciteit van de behandeling te bepalen, zal de toxiciteit dus zeker niet onderschat worden. Ook bleek dat we goed uit de vragenlijsten konden halen welke patiënten dermate ernstige bijwerkingen hadden, dat ze echt een keer op de polikliniek gezien moesten worden, om samen met hen te zoeken naar eventuele andere oorzaken van de klachten, en naar oplossingen 
te zoeken. Wij hebben derhalve geconcludeerd dat het mogelijk is om op vragenlijsten te vertrouwen om de toxiciteit inzichtelijk te maken.

\section{Discussie en toekomstperspectieven}

In hoofdstuk 6 worden de resultaten bediscussieerd en in een breder kader geplaatst.

Een belangrijk toekomstig doel is om met behulp van de resultaten van de Young Boost Trial een voorspellingsmodel betreffende de te verwachten cosmetiek te maken, dat gebruikt kan worden in de spreekkamer. De patiënte en de arts kunnen dan samen beslissen over de intensiteit van de bestraling (bijvoorbeeld wel of geen boost) waarbij de patiënte goed geïnformeerd kan worden over de voordelen (minder kans op terugkeer ziekte) en de nadelen (meer kans op bijwerkingen, zoals slechtere cosmetiek). Een belangrijke relatief nieuwe ontwikkeling is daarbij de oncoplastische chirurgie. Patiënten worden steeds vaker oncoplastisch geopereerd. Bij oncoplastische chirurgie wordt de lumpectomieholte gesloten en wordt de contour van de borst hersteld door het resterende borstweefsel te verplaatsen en/of te draaien. Het doel van deze operatie is uiteraard een fraaier cosmetisch resultaat. Het zou echter kunnen dat door de oncoplastische chirurgie (meer wonden in de borst als gevolg van verplaatsing, wellicht meer seroom) er juist meer fibrose als gevolg van de bestraling optreedt. Helaas zijn er nog weinig data over de resultaten van deze operatie op de langere termijn. Om meer informatie te verkrijgen over de late bijwerkingen, is het belangrijk om deze op een gestructureerde manier vast te leggen.

Hoewel we steeds meer weten van risicofactoren betreffende late bijwerkingen, bestaan er ook nog veel onduidelijkheden. Als gevolg hiervan is er bijvoorbeeld nog geen consensus over het optimale bestralingsplan. Is het bijvoorbeeld belangrijker om het hart zo maximaal mogelijk te sparen, met als gevolg een onderdosering aan de binnenzijde van de borst, of, in geval van een boost, een groter gebied in de borst die een hogere dosis krijgt met als gevolg een minder fraaie cosmetiek? Inmiddels is er in Nederland een project gestart ten behoeve van harmonisatie van planevaluatie, met als doel landelijke consensus te bereiken.

Om het hart te sparen tijdens de bestralingsbehandeling, hebben we laten zien dat de bestraling tijdens vrijwillige "breath hold" even goed reproduceerbaar is als bestraling in vrije ademhaling, zodat het een eenvoudige methode is om de kans op hartschade te verkleinen (hoofdstuk 4). Sinds kort hebben we in Nederland een drietal protonencentra. Met protonentherapie is het mogelijk heel nauwkeurig het doelgebied te bestralen en omgevende weefsels (zoals het hart) te sparen. Patiënten met borstkanker komen vooralsnog alleen in aanmerking voor deze behandeling als er met protonentherapie een klinisch relevante verlaging van het risico op late hartschade kan worden bereikt. Dit wordt nu ingeschat aan de hand van een model. Om de winst van de protonentherapie 
aan te tonen, is het scoren van late toxiciteit belangrijk. Zo kan op de lange termijn middels data aangetoond worden dat protonentherapie inderdaad leidt tot een verlaging van het risico op hartschade.

Er zijn dus meerdere argumenten om goede follow up data te verkrijgen. In dit proefschrift hebben we een voorstel gedaan over hoe dit mogelijk zou zijn (hoofdstuk 5).

\section{Conclusie:}

Concluderend hebben we verschillende aspecten van late bijwerkingen bestudeerd. Uit onze analyse bleek dat een hogere boost dosis in vergelijking met de standaard boost dosis, een fotonen boost in plaats van een elektronen boost, een al minder fraaie cosmetiek vóór start van de bestralingsbehandeling, een groter volume van de borst wat de boost dosis krijgt en het ondergaan van aanvullende chemotherapie, risicofactoren zijn om een minder fraaie borst te ontwikkelen. De volgende stap is het ontwikkelen van een nomogram om de cosmetische uitkomst te schatten, die gebruikt kan worden bij gedeelde besluitvorming over bestraling.

Bovendien hebben we geconstateerd dat onze techniek van vmDIBH net zo reproduceerbaar is als bestralingstherapie tijdens vrije ademhaling, waardoor het een eenvoudig en waardevol hulpmiddel is om het bestraalde hartvolume en daardoor late hartschade te verminderen. Momenteel wordt protonentherapie in Nederland geïmplementeerd om hartschade bij geselecteerde patiënten verder te verminderen.

Ten slotte hebben we aangetoond dat het scoren van late bijwerkingen door middel van patiënten vragenlijsten een zinvolle manier is om late bijwerkingen op een gestructureerde manier vast te leggen. Hiermee kunnen niet alleen patiënten worden geïdentificeerd die extra zorg nodig hebben, maar kunnen ook gegevens op groepsniveau worden geanalyseerd, b.v. tijd-trends binnen één instituut of verschillen tussen instituten. 
Chapter 8

Valorisation 


\section{Valorisation}

\section{Relevance}

Breast cancer is the most common cancer in women ${ }^{1}$. In the last decades, the incidence of breast cancer has risen. In the Netherlands, over 17.000 women were diagnosed with breast cancer in $2019^{2}$. At the same time, the treatment of breast cancer patients has improved substantially ${ }^{1,3}$, leading to a growing number of breast cancer survivors. Especially in the patient population with a good oncological prognosis, preventing late side effects becomes increasingly important.

In this thesis we mainly focussed on three late side effects, namely cosmetic outcome, as we believe cosmetic outcome is related to quality of life, quality of life in a broader sense and preventing radiation induced heart damage.

We analysed data of the Young Boost Trial regarding cosmetic outcome at 4 years of follow up. We investigated which symmetry features are most important for patients to be satisfied with the appearance of her breast after breast conserving therapy. These findings might be relevant for surgeons, when they need to decide about surgery techniques. Further, we were able to define some radiation related factors and adjuvant chemotherapy as risk factors for worse cosmetic outcome ${ }^{5}$. Having knowledge about the Dose Volume Histogram parameters which are important for deterioration of cosmetic outcome, can be helpful for the radiation oncologist when reviewing the treatment plan. In literature many other risk factors for cosmetic outcome are known. Although there is still a lack in knowledge concerning the order of importance of the different risk factors and with that how to deal with them, we feel that these results can be helpful when informing patients about the risks and benefits of the radiation treatment.

We reported on the step-by-step implementation of a voluntary moderate deep inspiration breath hold technique ${ }^{6}$, a simple and inexpensive method to spare the heart in case of left sided breast cancer. It is known that dose to the heart can lead to heart damage, whereby the higher the dose in the heart, the higher the risk of heart disease during follow up. Therefore, it is important to keep the dose in the heart as low as possible. We showed a reproducible and affordable breath hold manoeuvre to reduce the dose to the heart. This paper can be helpful for radiation departments all over the world looking for a method to keep the dose in the heart as low as reasonable possible (ALARA).

At last, we investigated whether patient reported outcome measures (PROMs) are sufficiently reliable to record late outcome ${ }^{7}$. We concluded that it is possible to rely on questionnaires for recording late 
side-effects. These findings are very relevant for both breast cancer patients in the follow up as well as for breast cancer patients prior to the start of radiation therapy. By using PROMs, the patient can be saved a visit to the hospital during follow up. During consultation before start radiation therapy, patients can be informed regarding potential late side effects based upon the PROM data collected by the treating radiation therapy department. At last, we found that, although patients scored their toxicity a little higher than reported by the doctor at the outpatient clinic, questionnaires can be used to determine toxicity of treatment at a group level en therefore PROMs can be used for measuring quality of care.

\section{Target groups}

Breast cancer patients to be treated with curative intent, are the most important target group of this thesis. They may benefit directly or indirectly from the results obtained in this current thesis. For example, women with early breast cancer, treated with breast conserving therapy, can be better informed about the risk of deteriorated cosmetic outcome, if more is known about the risk factors predicting poor cosmetic outcome. These data, in addition to data collected by PROMs, can be used in the shared decision making conservation with the patient. In addition, by worldwide implementing the relatively simple technique of voluntary moderately deep inspiration breath hold, much less women will experience radiation-induced cardiac injury.

Furthermore, clinicians in the field of breast cancer and radiotherapy are likely to be interested in the results of our study. As a result of increasing attention of the government, health insurance companies and patient organizations for more transparency regarding quality indicators, it is important for all care providers to measure the quality of care. Using PROMs is a reliable method to record late effects of a treatment.

\section{Innovation}

Each of the studies in the current thesis has an innovative aspect. The Young Boost Trial is the only study with using a boost dose as high as 26 Gy. Further, the paper regarding the implementation of the voluntary moderate deep inspiration breath hold was the first article reporting on both set-up and in vivo dosimetric data obtained during breath hold, which is another form of innovation. At last, the development and design of the outpatient clinic for late outcome with the specific goal to investigate whether a visit to the hospital can be replaced by questionnaires to determine toxicity of the treatment can also be considered as innovative. 


\section{Planning \& Realisation}

The analysis of the cosmetic outcome in the Young Boost Trial have provided clues regarding the risk of a deteriorated cosmetic outcome. As described in the general discussion, the next step is to develop a nomogram to estimate cosmetic outcome. The results of PROMs will also allow development of prognostic models for other side effects that are considered to be relevant by patients. To find out exactly which late side effects patients consider to be relevant, a continuation of the BRASA study (a study with the aim to implement a decision aid for breast cancer and DCIS patients to decide on their radiation treatment) is currently under development. A workshop will be organized in which patients are asked patients for their opinion concerning relevant late side effects on which they might base their choice of treatment. In addition, patients are asked how this can best be visualized in the decision aid. In the future, these individualised predictions can then be used in shared decision making on radiation treatment.

In the Netherlands, proton therapy has become available for almost two years. Patients with breast cancer are only eligible for this treatment in The Netherlands, when a clinically relevant reduction in the risk of late heart damage can be achieved with proton therapy. For now, this clinically relevant reduction of heart injury is estimated based om a prognostic model. To prove the benefit of proton therapy, it is important to record late toxicity. In the long term, for example, data can be used to demonstrate that proton therapy does indeed reduce the risk of heart damage. Another application of the use of questionnaires / PROMS is, as mentioned above, to get insight in the toxicity of your own patient population. Radiotherapy departments will be able to compare (benchmark) their score on late toxicity with other radiotherapy departments. Departments that perform below average will be motivated to improve and the best performing departments can be asked to share their best practice with the other departments to allow them to improve. 


\section{References}

1. https://www.cijfersoverkanker.nl/. https://www.cijfersoverkanker.nl/.

2. https://borstkanker.nl.

3. Van Der Waal D, Verbeek ALM, Den Heeten GJ, Ripping TM, Tjan-Heijnen VCG, Broeders MJM. Breast cancer diagnosis and death in the Netherlands: A changing burden. Eur J Public Health. 2015;25(2):320-324.

4. Brouwers PJAM, van Werkhoven E, Bartelink $\mathrm{H}$, et al. Factors associated with patientreported cosmetic outcome in the Young Boost Breast Trial. Radiother Oncol. 2016;120(1):107-113.

5. Brouwers PJAM, van Werkhoven $\mathrm{E}$, Bartelink $\mathrm{H}$, et al. Predictors for poor cosmetic outcome in patients with early stage breast cancer treated with breast conserving therapy: Results of the Young boost trial. Radiother Oncol. 2018;128(3):434-441.

6. Brouwers PJAM, Lustberg T, Borger JH, et al. Set-up verification and 2-dimensional electronic portal imaging device dosimetry during breath hold compared with free breathing in breast cancer radiation therapy. Pract Radiat Oncol. 2015;5(3):e135-e141.

7. Brouwers PJAM, van Loon J, Houben RMA, et al. Are PROMs sufficient to record late outcome of breast cancer patients treated with radiotherapy? A comparison between patient and clinician reported outcome through an outpatient clinic after 10 years of follow up. Radiother Oncol. 2018;126(1):163-169. 
Dankwoord 


\section{Dankwoord}

Het zit erop! Mijn promotietraject is afgerond en 'het boekje' is klaar. Dit proefschrift was echter nooit tot stand gekomen zonder de bijdrage van anderen. Met het gevaar iemand te vergeten, excuus alvast daarvoor, zou ik toch graag een aantal mensen persoonlijk bedanken.

Om te beginnen alle patiënten die hebben deelgenomen aan de Young Boost Trial en alle patiënten die de moeite hebben willen nemen belangeloos naar de late effecten poli voor borstkanker te komen en/of de vragenlijst in te vullen. Deze poli dag was de dag dat ik mijn witte jas weer aan kon trekken en zo kon ik tijdens de bureau-jaren toch het contact met de kliniek onderhouden.

Uiteraard mijn oprechte dank voor mijn promotoren prof. dr. L.J. Boersma en prof. dr. D. de Ruysscher en mijn copromotor dr. J.G.M. van Loon. Beste Liesbeth, toen ik bij je aanklopte of je "iets" had voor de verplichte onderzoeksstage, had je een prachtig project klaarliggen, namelijk de cosmetiekanalyse van de Young Boost Trial. Omdat we de Young Boost trial niet wilden uitmelken, hebben we het onderwerp van deze thesis verbreed en ook de implementatie van de vmDIBH in het boekje opgenomen en samen de late effecten poli voor borstkanker opgezet. Dank voor je enthousiasme, het delen van je kennis, voor je begeleiding en vooral ook voor je geduld. Het heeft even geduurd, maar ik denk dat we nu toch een prachtig resultaat hebben afgeleverd. Je hebt al vele promovendi begeleidt als copromotor, maar ik ben de eerste promovendi waar jij de promotor van bent en daar ben ik ontzettend trots op! Beste Dirk, juist doordat borstkanker niet jouw aandachtsgebied is, kon je soms de vinger precies op de juiste plek leggen, waardoor bepaalde alinea's toch wat genuanceerd moesten worden of beter uitgelegd. Dank voor de immer kritische blik. Beste Judith, hoe bijzonder eigenlijk dat wij zijn begonnen als AIOS-collega's en dat je later mijn copromotor werd. Dank voor altijd de laatste blik. Vaak als ik dacht klaar te zijn, het document rondgestuurd werd met naamgeving .def, kwam jij nog met een paar laatste verbetertips $(;$

Ook zou ik graag de leden van beoordelingscommissie, professor René van der Hulst, dr. Astrid Scholten, dr. Desirée van den Bongard, professor Ignace de Hingh en dr. Stéphanie Peeters willen bedanken voor het (snelle!) beoordelen van mijn proefschrift en de bereidheid plaats te nemen in de beoordelingscommissie.

Ook alle co-auteurs van de artikelen verdienen een woord van dank, waarbij ik Erik van Werkhoven uit het AvL in het bijzonder wil noemen. Erik, dank voor het iedere keer weer analyseren wat wij vroegen en dank voor de herhaalde uitleg van het proportional odds principe.

John Paulissen, dank voor je hulp in de late effectenpoli. Zonder jou had ik er $2 x$ zo lang over gedaan om alle patiënten te zien. 
Bianca Hanbeukers, dank voor je hulp bij het evalueren van de cosmetiek. Duizenden foto's moesten door BCCT.core geanalyseerd worden. Heel fijn dat ik ze niet allemaal alleen hoefden te doen!

Alle datamanagers, doktersassistenten en secretaresses die ervoor gezorgd hebben dat de late effectenpoli zo goed liep, dank! Ook de datamanagers van het Antonie van Leeuwenhoek ziekenhuis, dank voor alle queries die jullie zowel nationaal als internationaal uitgezet hebben zodat de database uiteindelijk toch compleet was.

Ruud Houben, dank voor je statistische hulp. Ondanks echt goede cijfers voor Wiskunde $A$ en het statistiek tentamen, had ik de papers niet zonder jouw hulp kunnen schrijven.

Wie zeker niet vergeten mag worden is Mariëlle Vincken. Mariëlle, ik heb het eerder gezegd en ik herhaal het nu weer: je bent een engel! Zo ontzettend fijn dat je de secretariële ondersteuning rondom de goedkeuring van mijn promotie, alle papieren rompslomp en het plannen van de datum op je hebt willen nemen. Een en ander werd je niet gemakkelijk gemaakt door de universiteit hack en de coronacrisis, maar je hebt het toch maar mooi geregeld voor me, ontzettend bedankt!

Antoinette Mulder, dank voor het ontwerpen van de kaft van mijn boekje. Ik had iets in m'n hoofd en je wist nog net iets mooiers te tekenen dan ik eigenlijk in mijn hoofd had.

Inmiddels werk ik alweer ruim 1 jaar met heel veel plezier in het ZRTI als radiotherapeut-oncoloog. Bedankt lieve collega's voor de fijne werkomgeving, de belangstelling en de steun. Zo fijn als er de dag nadat je verlof hebt opgenomen om eens 2 dagen achter elkaar ongestoord te kunnen werken, er een blokje 'administratie proefschrift' in je agenda staat :-

Ook iedereen bedankt die mij als radiotherapeut-oncoloog hebben gevormd. Om te beginnen alle oud-AIOS waar ik zo'n gezellige opleidingstijd mee heb gehad. Daarnaast alle (oud)radiotherapeutoncologen van Maastro en het Catharina Ziekenhuis en in het bijzonder al mijn opleiders en plaatsvervangend opleiders Philippe Lambin, Jos Jager, Rinus Wanders, Angela van Baardwijk, Tom Budiharto en Hetty van den Berg bedankt voor het opleiden van mij. Zonder jullie was ik nooit de arts geworden die ik nu ben. Ook alle oud-collega's uit het Leids Universitair Medisch Centrum en het Reinier de Graaf Gasthuis bedankt voor de fijne tijd in de randstad. De transformatie van AIOS naar medisch specialist heb ik in een veilige omgeving mogen maken.

Ook dank voor Maaike en Hanneke dat ze mijn paranimfen willen zijn. Lieve Maaike, jij was al AIOS toen ik begon. Gelukkig heb je mij mijn goedbedoelde, maar minder geslaagde opmerking heel snel vergeven en zaten wel al heel snel meermaals per week samen op de spinningfiets en later op de mountainbike. Jij hebt het Zeeuwse verruild voor Zuid-Limburg, ik ben nu juist in Zeeland beland. Grappig dat onze laatste stelling dezelfde is! Lieve Hanneke, ergens halverwege mijn opleiding kwam 
bij de AIOS-groep binnenstormen als vrolijke enthousiasteling. Samen hebben we een ontzettend gezellige tijd in Eindhoven gehad en hebben we zelfs "samen" Maastrichts Mooiste gelopen. Fijn dat je weer terug aan de slag gaat als radiotherapeut-oncoloog. Zonde van zo'n lieve en prettige dokter als de witte jas aan de wilgen wordt gehangen!

Mijn vrienden en familie wil bedanken voor al het geduld wat ze met me hebben gehad. Regelmatig heb ik het af laten weten bij een verjaardag omdat ik echt achter de laptop moest kruipen. Tegelijkertijd wil ik jullie ook bedanken voor alle leuke dingen waar ik wel bij kon zijn. Aangezien de totstandkoming van dit proefschrift meerdere jaren heeft geduurd, kon de boog echt niet altijd gespannen staan. Mar \& Wout, Steef \& Sander, Heico \& Eef en Ed \& Triz, op het vriendenweekend van 2 jaar geleden kon ik echt weer even teren! Frank \& Pascalle, altijd gezellige logeerpartijen na een high tea en de kermis. Bea en Sara, wat bof ik dat ik jullie zo snel heb leren kennen hier in Middelburg. Dankzij jullie voel ik me al helemaal thuis en ik hoop dat er nog vele gezellige BBQ / spelletjes / concert avondjes mogen volgen!

Lieve papa en mama, bedankt voor alles! Jullie hebben mij altijd gesteund, niet alleen tijdens mijn promotietraject, maar door alle jaren heen. Zowel tijdens de opleiding, als alle verhuizingen, altijd hebben jullie mij geholpen waar mogelijk was. Altijd hebben jullie oprechte interesse getoond in mijn werkzaamheden en jullie hebben me altijd laten weten dat jullie trots op mij zijn. Ik ben blij dat ik jullie als ouders heb!

Annemarie en Jeroen, mijn grote zus en "kleine" broertje. Als pubers boterde het niet altijd even goed, gelukkig zijn we inmiddels volwassen en zijn we opgedroogd als een leuk gezin met altijd gezellige familievakanties. Ook al wonen we niet naast de deur, hopelijk komt er nu toch wat meer tijd om weer eens gezellig samen af te spreken, nu ik niet altijd 'nog iets moet doen'.

Tot slot mijn lieve Martijn, dank dat je voor mij de keuze om te gaan promoveren zoveel gemakkelijker hebt gemaakt door naar Maastricht te verhuizen. Dank voor je technische hulp, door jouw programmeer-tool spraken de data veel meer tot mijn verbeelding. Dank voor je geduld en begrip als ik weer aan het werk moest. Dank voor je opbeurende woorden en knuffels als ik er even doorheen zat. Maar vooral wil ik je bedanken voor wie je bent, en dat je mij laat zijn wie ik ben. 
Curriculum Vitae 


\section{Curriculum vitae}

Patricia Brouwers werd geboren op 23 mei 1980 in de Moer (gemeente Loon op Zand), waar zij ook opgroeide. Na het VWO aan het Teresialyceum te Tilburg startte zij in 1998 met de opleiding geneeskunde aan de Erasmus Universiteit Rotterdam. Na het artsexamen in februari 2005 was zij werkzaam als arts-assistent-niet-in-opleiding bij de afdeling chirurgie in het Ruwaard van Putten ziekenhuis in Spijkenisse, als arts-assistent-niet-in-opleiding op de intensive care van het Elisabeth Ziekenhuis Tilburg, als arts-assistent-niet-in-opleiding spoedeisende hulp van het Elisabeth Ziekenhuis/Tweesteden Ziekenhuis Tilburg en als arts-assistent-niet-in-opleiding bij de afdeling radiotherapie in het Instituut Verbeeten. Bij deze laatste vond zij bevestiging betreffende de specialisatie richting, waarna zij in september 2009 startte met de opleiding radiotherapie bij MAASTRO clinic met als opleiders dr. A van Baardwijk en drs. R. Wanders (aanvankelijk dr. J. Jager en prof. Dr. P. Lambin). Tijdens de perifere stage in het Catharina Ziekenhuis te Eindhoven in het laatste jaar waren de opleiders dr. T. Budiharto en drs. H. van de Berg.

De opleiding werd van 2013 t/m 2015 onderbroken voor haar promotieonderzoek, onder begeleiding van prof. dr. L.J. Boersma, dr. J.G.M. van Loon en prof. dr. D. de Ruysscher. Haar promotieonderzoek betrof de late effecten van bestraling bij patiënten met borstkanker, waarbij risicofactoren betreffende cosmetiek werden geanalyseerd op basis van data uit de Young Boost Trial. Ook werd een simpele breath hold beschreven om het hart tijdens de bestraling zoveel mogelijk uit het bestralingsveld te bewegen en werd onderzocht of late effecten scoren in de follow up ook mogelijk is middels vragenlijsten.

De opleiding werd voltooid in september 2017, waarna zij startte als radiotherapeut-oncoloog in het LUMC in Leiden. Sinds mei 2019 is zij werkzaam als radiotherapeut-oncoloog bij het Zuidwest Radiotherapeutisch Instituut in Vlissingen. Haar huidige aandachtsgebieden zijn mammatumoren, gastro-intestinale tumoren en urologische tumoren. 


\section{Publications}




\section{Publications}

Patricia J.A.M. Brouwers, Erik van Werkhoven, Harry Bartelink, Alain Fourquet, Claire Lemanski, Judith van Loon, John H. Maduro, Nicola S. Russell, Luc J.E.E. Scheijmans, Dominic A.X. Schinagl, Antonia H. Westenberg h, Philip Poortmans, Liesbeth J. Boersma, on behalf of the Young Boost Trial research group. Predictors for poor cosmetic outcome in patients with early stage breast cancer treated with breast conserving therapy: Results of the Young boost trial Radiotherapy and Oncology 2018 Sep; 128 (3); 434-441

P.J.A.M. Brouwers, J. van Loon, R.M.A. Houben, J. Paulissen, S.M.E. Engelen, M. Heuts, M. de Boer, K. Verhoeven, D. De Ruysscher, L.J. Boersma. Are PROMs sufficient to record late outcome of breast cancer patients treated with radiotherapy? A comparison between patient and clinician reported outcome through an outpatient clinic after 10 years of follow up Radiotherapy and Oncology 2018 Jan; 126 (1) 163-169

Brouwers PJ, van Werkhoven E, Bartelink H, Fourquet A, Lemanski C, van Loon J, Maduro JH, Russell NS, Scheijmans LJ, Schinagl DA, Westenberg AH, Poortmans P, Boersma LJ; Young Boost Trial research group. Factors associated with patient-reported cosmetic outcome in the Young Boost Breast Trial Radiother Oncol. 2016 Jul;120(1):107-13

Lambin P, Zindler J, Vanneste BG, De Voorde LV, Eekers D, Compter I, Panth KM, Peerlings J, Larue RT, Deist TM, Jochems A, Lustberg T, van Soest J, de Jong EE, Even AJ, Reymen B, Rekers N, van Gisbergen M, Roelofs E, Carvalho S, Leijenaar RT, Zegers CM, Jacobs M, van Timmeren J, Brouwers P, Lal JA, Dubois L, Yaromina A, Van Limbergen EJ, Berbee M, van Elmpt W, Oberije C, Ramaekers B, Dekker A, Boersma L, Hoebers F, Smits KM, Berlanga AJ, Walsh S. Decision support systems for personalized and participative radiation oncology. Adv Drug Deliv Rev. 2016 Jan 14

Brouwers PJ, Lustberg T, Borger JH, van Baardwijk AA, Jager JJ, Murrer LH, Nijsten SM, Reymen BH, van Loon JG, Boersma LJ. Set-up verification and 2-dimensional electronic portal imaging device dosimetry during breath hold compared with free breathing in breast cancer radiation therapy. Pract Radiat Oncol. 2015 May-Jun;5(3) 
